OPEN ACCESS

Edited by:

Richard Ivell,

University of Nottingham,

United Kingdom

Reviewed by:

Jodi Anne Flaws,

University of Illinois at Urbana-

Champaign, United States

Benson T. Akingbemi,

Auburn University, United States

*Correspondence:

Helena E. Virtanen

helena.virtanen@utu.fi

Specialty section:

This article was submitted to

Reproduction,

a section of the journal

Frontiers in Endocrinology

Received: 07 May 2021 Accepted: 17 August 2021 Published: 07 October 2021

Citation:

Rodprasert W, Toppari J and Virtanen HE (2021) Endocrine

Disrupting Chemicals and Reproductive Health in Boys and Men.

Front. Endocrinol. 12:706532. doi: 10.3389/fendo.2021.706532

\section{Endocrine Disrupting Chemicals and Reproductive Health in Boys and Men}

\author{
Wiwat Rodprasert $^{1,2}$, Jorma Toppari ${ }^{1,2,3}$ and Helena E. Virtanen ${ }^{1,2 *}$ \\ ${ }^{1}$ Research Centre for Integrative Physiology and Pharmacology, Institute of Biomedicine, University of Turku, Turku, Finland, \\ ${ }^{2}$ Centre for Population Health Research, University of Turku and Turku University Hospital, Turku, Finland, ${ }^{3}$ Department of \\ Pediatrics, Turku University Hospital, Turku, Finland
}

Male reproductive health has declined as indicated by increasing rates of cryptorchidism, i.e., undescended testis, poor semen quality, low serum testosterone level, and testicular cancer. Exposure to endocrine disrupting chemicals (EDCs) has been proposed to have a role in this finding. In utero exposure to antiandrogenic EDCs, particularly at a sensitive period of fetal testicular development, the so-called 'masculinization programming window (MPW)', can disturb testicular development and function. Low androgen effect during the MPW can cause both short- and long-term reproductive disorders. A concurrent exposure to EDCs may also affect testicular function or damage testicular cells. Evidence from animal studies supports the role of endocrine disrupting chemicals in development of male reproductive disorders. However, evidence from epidemiological studies is relatively mixed. In this article, we review the current literature that evaluated relationship between prenatal EDC exposures and anogenital distance, cryptorchidism, and congenital penile abnormality called hypospadias. We review also studies on the association between early life and postnatal EDC exposure and semen quality, hypothalamic-pituitary-gonadal axis hormone levels and testicular cancer.

Keywords: anogenital distance, cryptorchidism, hypospadias, endocrine disrupters, endocrine disrupting chemicals, reproductive hormones, semen quality, testicular cancer

\section{INTRODUCTION}

Reports on deteriorating male reproductive health have been published in many countries. Serum testosterone levels and semen quality have been declining (1-3). In addition, the rates of congenital cryptorchidism, i.e. undescended testis, and testicular germ cell tumors have been increasing $(4,5)$. Exposure to endocrine disrupting chemicals (EDCs) has been proposed to be one of the causes of these adverse trends. This is because these chemicals are ubiquitous, we are exposed to them via food, skin and inhaled air. Environmental EDCs include for instance pesticides, chemicals used in plastic products [like phthalates and bisphenol A (BPA)], in personal care products (like triclosan and parabens), in hydraulic and electronic devices [like polychlorinated biphenyls (PCBs)], chemicals used in clothes (like perfluorinated compounds), flame retardants, solvents, chemicals produced unintentionally as side products in chemical processes (dioxins) and many others (6). 
Many experimental and epidemiological studies have supported links between EDC exposures and male reproductive health problems (7). Since development of male reproductive system requires androgens, substances that have antiandrogenic effects can disturb this process and possibly cause male reproductive disorders (Figure 1). Anti-androgenic chemicals with different mechanisms of actions (inhibition of androgen biosynthesis or receptor antagonism) show accumulative effects (8). This causes the risk that even low concentrations in mixtures can be harmful. Furthermore, non-monotonic dose-response to EDCs has been described $(9,10)$.

It has been proposed that the disruption of fetal testicular development due to, for example, maternal exposure to EDCs, can result in disorders manifested at birth, i.e., congenital cryptorchidism, congenital penile abnormality called hypospadias and reduced anogenital distance (AGD), as well as disorders presented later in life, including poor semen quality, testicular germ cell tumors, and altered reproductive hormone levels. This is the concept of testicular dysgenesis syndrome, TDS $(11,12)$. In addition, some studies have shown associations between postnatal EDC exposures and male reproductive disorders.

We will review the human epidemiological studies that investigated the association between pre- and postnatal EDC exposure (based on environmental chemical concentration measurements in different matrices) and above mentioned male reproductive health indicators (anogenital distance, cryptorchidism, hypospadias, semen quality, reproductive hormone levels in adults and testicular cancer) and were published in English by August 2020 and found in Pubmed. Heavy metals and pharmaceuticals are not included in this review, because medicines have been recently reviewed elsewhere (13) and because the effects of heavy metals are mostly toxic rather than endocrine modulating $(14,15)$.
However, we include organotins, because their action is clearly hormonal.

\subsection{Short Introduction to EDCs}

EDCs can disturb hormonal systems and may cause male reproductive disorders by a variety of mechanisms. Studies have shown that EDCs can have estrogenic, anti-estrogenic, androgenic or antiandrogenic effects (16). PCBs, polybrominated diphenyl ethers (PBDEs), phthalates, and bisphenol A can act on estrogen receptor and exert estrogenic effects $(7,16)$ In contrast, benzophenone- 3 and -4 and some PCBs showed antiestrogenic effects. Some ultraviolet (UV) filters, BPA, p, $\mathrm{p}^{\prime}$ -dichlorodiphenyldichloroethylene (p,p'-DDE), PBDEs and phthalates have antiandrogenic activity (16-20). PCB-138, -153, -180 , have pleiotropic effects on androgen and estrogen receptors $(19,20)$. Organochlorine compounds, including polychlorinated dibenzo-p-dioxins, dichlorodiphenyltrichloroethane (DDT), hexachlorobenzene (HCB) and PCBs, can bind to estrogen receptors and exert estrogenic effects or have antiandrogenic effects $(16,21-23)$. Only few EDCs have been reported to have androgenic activity, for example, benzophenone 2 (16). Dioxins can also bind to aryl hydrocarbon receptor (AhR), which functions in association with estrogen or androgen receptor $(7,24)$. Lastly, some EDCs can directly disturb spermatogenesis and cause poor semen quality.

\subsubsection{Persistent EDCs}

EDCs include persistent and non-persistent chemicals. Persistent organic pollutants include chemicals that can accumulate and are persistent in the body or environment. PCBs and DDT, are examples of lipophilic chemicals that can accumulate in adipose tissue, are slowly excreted, and therefore they can persist in the

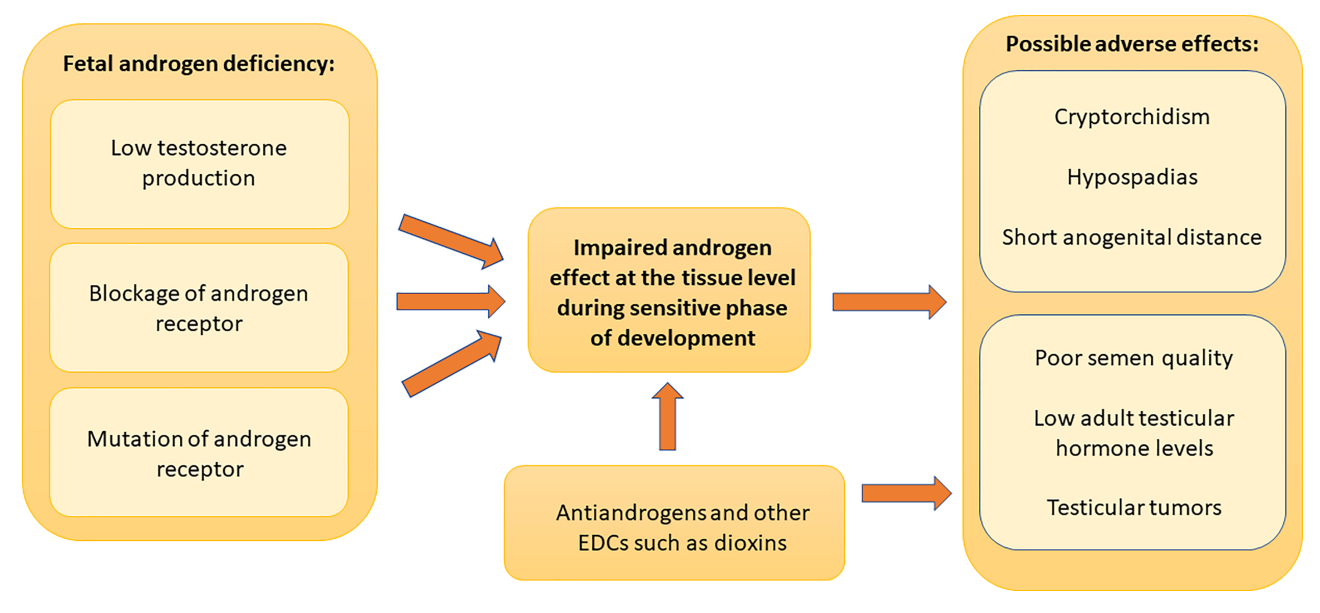

FIGURE 1 | Role of androgen effects in male reproductive disorders. Adequate androgen action during a sensitive period of development in male fetus is important for normal male reproductive organ development and function after birth. The lack of androgen action due to decreased testosterone synthesis, androgen receptor blockade or androgen receptor mutations can cause early or late postnatal male reproductive disorders. Early postnatal manifestations include cryptorchidism, hypospadias and decreased anogenital distance. Late postnatal manifestations consist of reduced semen quality, reduced adult reproductive hormone levels and testicular germ cell tumors. Fetal exposure to chemicals that have antiandrogenic effects can disturb male reproductive system development and can cause these manifestations. These chemicals can also cause postnatal antiandrogenic effects as shown by the direct arrow to the adult manifestations. There are also other possible mechanisms of action, and other endocrine disrupting compounds may also affect reproductive organs. Dioxin is a well-known example of such a chemical. 
body for a long time (25). Because of the long half-life, the adult levels of these chemicals can be used to study an association with prenatal exposure, although the timing of exposure is unclear.

\subsubsection{Pesticides}

Dichlordiphenyldichloroethylene (p,p'-DDE) is the most persistent congener of DDT. The effects of DDE and DDT may persist even though they were banned in 1970s-1980s (26, 27). DDT and p,p'-DDE can accumulate in body fat for many years (half-life of approximately 6 years for DDT and 10 years for p,p'-DDE) $(6,27,28)$. Persistent chemicals include also other organochlorine pesticides, for example lindane, chlordane and heptachlor (25).

\subsubsection{PCBs and Dioxins}

PCBs were widely used in industrial and consumer products. Even though their use was banned in the 1970s, they still persist in the environment and people continue to be exposed (29). They accumulate in body fat and have a half-life of 1 to 10 years. Humans are exposed to PCBs through ingestion of contaminated food, inhalation or skin contact (29). As mentioned above, dioxins are not produced intentionally, but they are formed as side products and humans are exposed to these persistent chemicals mainly via food of animal origin (30).

\subsubsection{Flame Retardants}

PBDEs are used as flame retardants and are found in house dust. The major routes of exposure are dust inhalation or ingestion $(31,32)$. They can exert anti-androgenic and estrogenic activity, which potentially leads to male reproductive disorders $(16,33)$. Also polybrominated biphenyls (PBBs) have been used as flame retardants (6).

\subsubsection{Perfluorinated Compounds}

Perfluorinated compounds (PFCs) are used in industry and consumer products, including surfactants, paints, lubricants and impregnation of clothes, textiles, footwear, furniture and carpets (34). Perfluorooctane sulfonate (PFOS) is the most abundant perfluoroalkyl substances (PFAS) in humans and in environment, followed by perfluorooctanoic acid (PFOA) $(35,36)$. PFOA was used in the production of polytetrafluoroethylene, which is used in non-stick coating cookware (37). Human exposure occurs via inhalation, ingestion and skin contact (38).

\subsubsection{Organotins}

Organotins have been used widely in industry, e.g., in antifouling paints of boats and ships and they have been observed to have endocrine-disrupting properties and adverse effect on male reproductive health $(6,39)$. Humans are exposed to them via contaminated seafood.

\subsubsection{Non-Persistent EDCs}

Non-persistent endocrine disrupting chemicals include, for example, BPA, parabens, triclosan, phthalates, synthetic pyrethroids and organophosphate pesticides (40).

\subsubsection{BPA and Other Phenols}

Bisphenol A is used in the lining of water supply pipes, aluminum cans, reusable plastic food containers, dental sealants, thermal receipts, medical equipment, and building supplies (41). Humans can be exposed to BPA via ingestion, inhalation or skin contact (42). It can act as a weak agonist of the estrogen receptor by binding to estrogen receptors (ER) ER $\alpha$ and $\operatorname{Er} \beta(43,44)$. It can also act as an androgen receptor antagonist $(45,46)$. It can cause reduced serum follicle-stimulating hormone (FSH), luteinizing hormone (LH) and testosterone levels (47). It can interfere $17 \alpha$-hydroxylase/17,20 lyase and aromatase, which are important steroidogenic enzymes of Leydig cells (46). In addition, it can cross the placenta from mothers to the fetus, but its concentration in fetal circulation is much lower than in mother and thus, the placenta appears to reduce BPA exposure of the fetus (48). BPA is metabolized in the liver and excreted in urine with plasma half-life of six hours (46). Therefore, the standard method of BPA measurement is analysis of urinary levels $(42,49)$. Bisphenol $\mathrm{S}$ was used as a potentially safer substitute for BPA. However, a limited number of studies showed that it also has estrogenic, androgenic, and antiandrogenic effects (50), and therefore it might have adverse reproductive effects in humans. Triclosan is an antimicrobial agent used for instance in personal care products and it is also a phenol (6).

\subsubsection{Phthalates}

Phthalates are ubiquitous chemicals, which are widely used as plasticizers, a component of polyvinyl chloride (PVC), excipients in some medications, personal care products, solvents or adhesives (51). Humans are exposed to phthalates via ingestion, which is the main route of exposure, inhalation, intravenous administration and through direct skin contact (51). After entering the human body, phthalates are rapidly metabolized into monoesters, which are excreted into urine with a half-life of 12 hours $(52,53)$. Therefore, phthalate measurement from urine results in a higher level than from other biological samples, and urine is the most frequently used sample in epidemiological studies (54).

\subsubsection{Parabens}

Parabens belong to a group of esters of p-hydroxybenzoic acid. They have antibacterial and antifungal properties, therefore they are used as preservatives in personal care products, cosmetics, foodstuffs and some pharmaceuticals (55-57). They show weak estrogenic effect in vitro (57). Parabens belong to nonhalogenated phenols (6).

\subsubsection{Non-Persistent Pesticides}

Non-persistent pesticides include for instance organophosphates, pyrethroids, and carbamates. Some of these chemicals have been shown to have endocrine disrupting effects and may cause male reproductive disorders $(58,59)$.

\subsubsection{Solvents}

Solvents are widely present in occupational and consumer products, such as cleaning products and cosmetics. These chemicals include for instance glycol ethers, some of which have been shown to affect testicular function and expression of estrogen and androgen receptors in the testis $(60,61)$. 


\section{REPRODUCTIVE OUTCOMES}

\subsection{Anogenital Distance}

Anogenital distance has been measured either as anoscrotal distance, i.e., the distance between anus and perineoscrotal junction, or as an anopenile distance, i.e., the distance between anus and cephalad insertion of the penis. Sometimes also the distance from the centre of the anus to the posterior base of the penis was recorded (62). Anogenital distance is considered to be a life-long marker of androgen exposure in the prenatal male programming window $(\mathrm{MPW})$, at least in rats $(63,64)$. In humans, MPW is presumed to be in gestational weeks (GW) 8-14 (63). Prenatal exposure to antiandrogenic EDCs has been associated with short AGD in male rats [reviewed in (65)]. Several human studies have evaluated associations between prenatal EDC exposure and anogenital distance in infant and young boys (Table 1).

Many, but not all, studies listed in Table $\mathbf{1}$ suggested negative associations between anoscrotal or anopenile distance and phthalate levels in maternal urine samples collected during pregnancy. A recent meta-analysis found that sum of $\operatorname{di}(2-$ ethylhexyl) phthalate (DEHP) metabolites in maternal urine was associated with a risk of short anoscrotal and anopenile distance in the son (97). In addition, monoethylhexyl phthalate (MEHP), mono(2-ethyl-5-hydroxyhexyl) phthalate (MEHHP), mono(2-ethyl-5-oxohexyl) phthalate (MEOHP) and mono(2ethyl-5-carboxypentyl) phthalate(MECPP) levels (metabolites of DEHP) were associated with the risk of shortened anopenile and anoscrotal distance (97). Furthermore, monobutyl phthalate (MBP), monoethyl phthalate (MEP), and monoisobutyl phthalate (MiBP) levels were associated with the risk of shortened anopenile distance (97). A previously published systematic review included less studies than our review or the above-mentioned recent meta-analysis and it suggested moderate evidence for a negative association between DEHP and dibutylphthalate (DBP) exposure and anogenital distance in boys, and slight evidence for diisononyl phthalate (DiNP), butyl benzyl phthalate (BBP), diethyl phthalate (DEP) and diisobutyl phthalate (DiBP) (51).

In Table 1, three out of four studies suggested a negative association between PCB or PBDE exposure levels and anogenital distance. BPA/phenol levels were negatively associated with anogenital distance in less than half of the listed studies. Negative associations between pesticide exposure levels (different chemicals included) and anogenital distance in the boys were reported in less than half of the studies. For some chemical groups, only a few human studies have been published so far and it is difficult to draw any conclusions. Differences in results of the studies may be explained by variation in exposure levels, in timing of the sample collection, in matrices analyzed, in the age of the boys at examination, in other factors included in the statistical analysis (e.g., stress), and in metabolites/chemicals analyzed. It also has recently been suggested that human-rodent differences in results concerning associations between prenatal EDC exposure and anogenital distance could be due to species differences in regulation of fetal androgen production (98).

\subsection{Cryptorchidism}

Congenital cryptorchidism, i.e. undescended testis, is one of the most common congenital malformations in newborn boys and prevalences between 1 and 8 percentage have been reported in full term boys in prospective cohort studies (4). Testicular descent from the intra-abdominal position into the scrotum is usually completed by 35th GW [reviewed in (99)]. Proper androgen action is important especially for the last phase of testicular descent, the inguinoscrotal phase (100). Furthermore, the first phase of testicular descent is, at least in mice, dependent on insulin-like peptide 3 (INSL3), a hormone produced by Leydig cells, and estrogens have been shown to downregulate the expression of INSL3 gene $(99,101)$. Therefore, fetal exposure to environmental chemicals with anti-androgenic and estrogenic properties might be associated with cryptorchidism in boys.

For pesticides, several studies have been published, and nine out of 14 studies listed in Table 2 suggested no significant association with the risk of cryptorchidism. All but two studies (one for each group) in Table 2 found no significant association between $\mathrm{PCB}$ or phthalate exposure levels and the risk of cryptorchidism. Two out of five studies suggested that PBDE exposure levels are positively associated with the risk of cryptorchidism. For phenols, two out of five studies suggested positive association between BPA exposure levels and the risk of cryptorchidism. For dioxins, perfluorinated compounds, parabens, organotins and solvents, only a few studies have been published so far and it is difficult to draw any conclusions. In a study evaluating simultaneously the risk of cryptorchidism and levels of several congeners of different chemical groups, levels of four PBDEs and octachlorodibenzofuran (OCDF) were significantly higher in the group representing Danish cryptorchid boys when compared with controls (131).

Bonde et al. studied associations between in utero or infant exposure to environmental EDCs and cryptorchidism in a metaanalysis (132). The analysis included studies based on chemical measurements of different biological matrices. No significant association was observed between exposure to environmental EDCs and cryptorchidism, when including eight studies in the analysis (132).

\subsubsection{Association Between EDC Exposure and Hormone Levels in Early Life}

Some of the above mentioned studies on cryptorchidism or anogenital distance have suggested association between EDC exposure levels and reproductive hormone levels of boys in amniotic fluid, cord blood or in serum samples taken at 3 months of age $(79,83,103,106,107,110,114,115,126,128,129)$. In Danish case-control studies on cryptorchidism, amniotic fluid DEHP and DiNP metabolite and PFOS levels associated positively with amniotic fluid testosterone (T) levels and negatively with amniotic fluid Insulin-like peptide 3 (INSL3) levels $(114,115,128)$. In French case-control studies on cryptorchidism, cord blood levels of BPA correlated negatively with cord blood INSL3 levels (110) and unconjugated BPA levels correlated positively with cord blood T and inhibin B levels (126). Maternal breast milk levels of PCB153, $\mathrm{DDE}$ or $\mathrm{mBP}$ did not correlate with cord blood INSL3 or T levels 
TABLE 1 | Studies on the association between exposure to different classes of environmental EDCs (based on matrix measurements) and anogenital distance in young boys.

\begin{tabular}{|c|c|c|c|c|c|}
\hline Reference & matrix & $\begin{array}{l}\text { Chemicals/ } \\
\text { congeners analysed }\end{array}$ & $n$ of subjects & Country & $\begin{array}{c}\text { Association between chemical } \\
\text { levels and AGD }\end{array}$ \\
\hline
\end{tabular}

\section{Dioxins}

Vafeiadi (66)

Maternal plasma collected at delivery

\section{Flame}

retardants

García-Villarino

(67)

Luan (68)

Cord plasma

García-Villarino

et al. (69)

García-Villarino

(67)

Parabens

Fisher (70)

Maternal serum at first trimester of pregnancy

Maternal serum at first trimester

Maternal serum during pregnancy

\section{PCBs}

García-Villarino

(67)

García-Villarino

(69)

García-Villarino

et al. (67)

Loreto-Gómez

et al. (62)

\section{Perfluorinated}

compounds

Arbuckle (71)

Maternal plasma during

first trimester

Maternal serum at first

trimester of pregnancy

Maternal serum at first

trimester

Maternal serum during

third trimester of

pregnancy
Plasma dioxin-like activity

6 PBDEs

116 4-y old boys

190 boys [measured at birth $(n=182)$, at 6 mo $(n=148)$, at $12 \mathrm{mo}(n=149)$, or at $48 \mathrm{mo}$ $(n=158)]$

PBDE-28, -99, -153 27 18-mo-old boys

6 PBDEs

74 4-y old boys

6 parabens

237

116 4-y old boys

PCB-28, -52

27 18-mo-old boys

6 PCBs

7 PCBs

74 boys, followed at 0, 1, 3, 6 and 12 mo

\section{4-y old boys}

PFOA, PFOS and 205 newborn boys

PFHXS

Lind (72)

Maternal serum during first trimester PFNA, and PFDA

Tian (73)

Maternal plasma during pregnancy

\section{Pesticides}

García-Villarino cord blood
(67)

Bornman (74) Maternal serum at delivery

or after it

PFOS, PFOA, PFHXS,

Eleven PFASs

316 boys examined 3 months after expected date of delivery

500 boys examined at least once at birth $(n=439)$, at $6(n=322)$ or at 12 months $(n=301)$

beta- $\mathrm{HCH}$, gamma-

$\mathrm{HCH}$ (lindane), $\mathrm{HCB}$,

4,4'-DDT, 4,4'-DDE,

$4,4^{\prime}$-DDD,

DDT, DDE
116 4-y old boys

343 at newborn, 344 at 1 year (follow-up)
Greece

Spain plasma dioxin-like activity.

Spain

China highest quartile of BDE-47 and sum of 4 PBDEs at 12 or 48 mo. Mid-range levels of BDE-28 were associated with shorter anopenile distance at 48 months of age.

Spain Anoscrotal distance/weight was negatively associated with PBDE99 and PBDE-153 levels

Spain Levels of PBDE-209 were negatively associated with anoscrotal distance/weight

UK Detection of n-Propyl paraben was associated with shorter anoscrotal distance from birth to 24 mo of age

Spain PCB-153 and -180 levels were negatively associated with anoscrotal distance/weight

Spain NS

Spain PCB-138 (second tertile), -153 (second tertile), -180 levels were negatively associated with anoscrotal distance/weight Significant negative association between anopenile distance/height and PCB 28, 74, and 170 levels (individually and combined).

Canada PFOA levels showed positive association with anoscrotal distance, but no dose-response effect

Denmark No consistent association between PFASs levels and anopenile or anoscrotal distance

China PFOS, PFDA, PFUdA and PFTrDA levels were negatively associated with anoscrotal or anopenile distance at 0 or at 6 months.

Spain NS

South NS

Africa 
TABLE 1 | Continued

\begin{tabular}{|c|c|c|c|c|c|}
\hline Reference & matrix & $\begin{array}{l}\text { Chemicals/ } \\
\text { congeners analysed }\end{array}$ & $\mathrm{n}$ of subjects & Country & $\begin{array}{c}\text { Association between chemical } \\
\text { levels and AGD }\end{array}$ \\
\hline $\begin{array}{l}\text { García-Villarino } \\
\text { (69) }\end{array}$ & $\begin{array}{l}\text { Maternal serum at first } \\
\text { trimester of pregnancy }\end{array}$ & $\begin{array}{l}\text { 2,4-DDD, 4,4-DDD, } \\
\text { HCB }\end{array}$ & 27 18-mo-old boys & Spain & NS \\
\hline $\begin{array}{l}\text { García-Villarino } \\
\text { et al. (67) }\end{array}$ & $\begin{array}{l}\text { Maternal serum at first } \\
\text { trimester }\end{array}$ & $\begin{array}{l}\text { beta-HCH, gamma- } \\
\mathrm{HCH} \text { (lindane), HCB, } \\
4,4^{\prime} \text {-DDT, } 4,4^{\prime} \text {-DDE, } \\
4,4^{\prime} \text {-DDD, }\end{array}$ & 74 4-y old boys & Spain & NS \\
\hline Longnecker (75) & $\begin{array}{l}\text { Maternal serum } \\
\text { postpartum }\end{array}$ & DDT, DDE & 781 newly delivered infants & Mexico & NS \\
\hline $\begin{array}{l}\text { Loreto-Gómez } \\
\text { (62) }\end{array}$ & $\begin{array}{l}\text { Maternal serum during } \\
\text { third trimester of } \\
\text { pregnancy }\end{array}$ & $\begin{array}{l}o, p^{\prime}-D D T, p, p^{\prime}-D D T \\
p, p^{\prime}-D D E\end{array}$ & 74 boys, followed at $0,1,3,6$ and 12 mo & Mexico & $\begin{array}{l}\text { Significant positive association } \\
\text { between p,p'-DDE and anopenile } \\
\text { length/height. Negative association } \\
\text { between mixture of DDT isomers } \\
\text { and its metabolites and anopenile } \\
\text { length/height. }\end{array}$ \\
\hline $\begin{array}{l}\text { Torres-Sanchez } \\
\text { (76) }\end{array}$ & $\begin{array}{l}\text { Maternal serum before } \\
\text { and during pregnancy }\end{array}$ & $\begin{array}{l}\mathrm{p}, \mathrm{p}^{\prime}-\mathrm{DDE} \text { and } \mathrm{p}, \mathrm{p}^{\prime}- \\
\text { DDT }\end{array}$ & 37 boys (age 3, 6, 12 or 18 months) & Mexico & $\begin{array}{l}\text { Significant negative association } \\
\text { between anal position index } \\
\text { (anoscrotal distance per coccyx- } \\
\text { scrotal distance) and first trimester } \\
\text { DDE levels. }\end{array}$ \\
\hline Dalsager (77) & $\begin{array}{l}\text { Maternal urine during } \\
\text { gestation (gw 28) }\end{array}$ & $\begin{array}{l}\text { pesticide metabolites } \\
\text { 3-PBA, TCPY, 2,4-D } \\
\text { and DAPs }\end{array}$ & $\begin{array}{l}420 \text { boys examined } 3 \text { months after expected } \\
\text { date of delivery }\end{array}$ & Denmark & $\begin{array}{l}\text { 2,4-D levels: Second tertile } \\
\text { compared to the first tertile was } \\
\text { associated with shorter anoscrotal } \\
\text { and anopenile distance }\end{array}$ \\
\hline \multicolumn{6}{|l|}{ Phenols } \\
\hline Mammadov (78) & Cord serum & BPA & 72 newborn boys & Cyprus & $\begin{array}{l}\text { BPA level above the } 90^{\text {th }} \\
\text { percentile was associated with } \\
\text { significantly shorter anoscrotal } \\
\text { distance. }\end{array}$ \\
\hline Sunman (79) & Cord blood & BPA & $\begin{array}{l}100 \text { newborns ( } 4 \text { had hypospadias, } \\
3 \text { cryptorchidism, } \\
7 \text { retractile testes) }\end{array}$ & Turkey & $\begin{array}{l}\text { Anogenital distance/weight } \\
\text { correlated significantly with BPA } \\
\text { levels (only in univariate analysis) }\end{array}$ \\
\hline Fisher (70) & $\begin{array}{l}\text { Maternal serum during } \\
\text { pregnancy }\end{array}$ & 9 phenols & 234 & UK & NS \\
\hline Arbuckle (80) & $\begin{array}{l}\text { Maternal first trimester } \\
\text { urine sample }\end{array}$ & BPA, Triclosan & 198 newborn boys & Canada & NS \\
\hline Huang (81) & $\begin{array}{l}\text { Maternal urine collected } \\
\text { during pregnancy }\end{array}$ & BPA, nonylphenol & 86 newborn boys & Taiwan & NS \\
\hline Lassen (82) & $\begin{array}{l}\text { Maternal urine during } \\
\text { pregnancy }\end{array}$ & Triclosan & $\begin{array}{l}245 \text { examined } 3 \text { months after expected date } \\
\text { of delivery }\end{array}$ & Denmark & $\begin{array}{l}\text { Negative association between } \\
\text { triclosan levels and anogenital } \\
\text { distance (borderline significance) }\end{array}$ \\
\hline Liu (83) & $\begin{array}{l}\text { Maternal urine during } \\
\text { pregnancy (third trimester) }\end{array}$ & $\begin{array}{l}\text { BPA, 4-nonylphenol, } \\
\text { 4-t-octylphenol. }\end{array}$ & 137 newborn boys & China & NS \\
\hline Sun (84) & $\begin{array}{l}\text { Maternal urine collected } \\
\text { during pregnancy }\end{array}$ & $\mathrm{BPA}$ & $\begin{array}{l}555 \text { newborn boys, follow-up at } 6 \text { months } \\
(n=343) \text { and at } 12 \text { months }(n=320)\end{array}$ & China & $\begin{array}{l}\text { Maternal exposure to BPA was } \\
\text { associated with shorter anoscrotal } \\
\& \text { anopenile distance of the son at } \\
12 \text { months. No dose-response } \\
\text { relationship }\end{array}$ \\
\hline \multicolumn{6}{|l|}{ Phthalates } \\
\hline Huang (85) & Amniotic fluid & $\begin{array}{l}\text { Five phthalate } \\
\text { metabolites }\end{array}$ & 33 newborn boys & Taiwan & NS \\
\hline Sunman (79) & Cord blood & DEHP, MEHP & $\begin{array}{l}100 \text { newborns ( } 4 \text { had hypospadias, } \\
3 \text { cryptorchidism, } \\
7 \text { retractile testes) }\end{array}$ & Turkey & $\begin{array}{l}\text { DEHP levels showed negative } \\
\text { association with anogenital index. }\end{array}$ \\
\hline Fisher (70) & $\begin{array}{l}\text { Maternal serum during } \\
\text { pregnancy }\end{array}$ & $\begin{array}{l}16 \text { phthalate } \\
\text { metabolites }\end{array}$ & 239 & UK & NS \\
\hline Adibi (86) & $\begin{array}{l}\text { Maternal first trimester } \\
\text { urine sample }\end{array}$ & 8 phthalate metabolites & 354 newborn boys & USA & $\begin{array}{l}\text { MnBP and MEHP levels were } \\
\text { negatively associated with } \\
\text { anoscrotal distance }\end{array}$ \\
\hline Arbuckle (80) & $\begin{array}{l}\text { Maternal first trimester } \\
\text { urine sample }\end{array}$ & $\begin{array}{l}11 \text { phthalate } \\
\text { metabolites }\end{array}$ & 198 newborn boys & Canada & $\begin{array}{l}\text { MnBP levels and molar sum of low } \\
\text { molecular weight phthalate } \\
\text { metabolites were positively }\end{array}$ \\
\hline
\end{tabular}


TABLE 1 | Continued

\begin{tabular}{|c|c|c|c|c|c|}
\hline Reference & matrix & $\begin{array}{l}\text { Chemicals/ } \\
\text { congeners analysed }\end{array}$ & $\mathrm{n}$ of subjects & Country & $\begin{array}{l}\text { Association between chemical } \\
\text { levels and AGD }\end{array}$ \\
\hline & & & & & $\begin{array}{l}\text { associated with anopenile } \\
\text { distance. }\end{array}$ \\
\hline Barrett (87) & $\begin{array}{l}\text { Maternal first trimester } \\
\text { urine sample }\end{array}$ & 9 phthalate metabolites & 366 newborn boys & USA & $\begin{array}{l}\text { Molar sum of DEHP metabolites, } \\
\text { and levels of MEOHP and MEHHP } \\
\text { were negatively associated with } \\
\text { anoscrotal and anopenile distance } \\
\text { in the lower stress group. In the } \\
\text { lower stress group MECPP and } \\
\text { MnBP levels were negatively } \\
\text { associated with anoscrotal } \\
\text { distance. }\end{array}$ \\
\hline Bornehag (88) & $\begin{array}{l}\text { Maternal first trimester } \\
\text { urine }\end{array}$ & $\begin{array}{l}\text { Ten phthalate } \\
\text { metabolites }\end{array}$ & 196 boys (mean age 21 months) & Sweden & $\begin{array}{l}\text { Levels of oh-MMeOP and oxo- } \\
\text { MMeOP and sum of DiNP } \\
\text { metabolites were negatively } \\
\text { associated with anoscrotal } \\
\text { distance }\end{array}$ \\
\hline $\begin{array}{l}\text { Bustamante- } \\
\text { Montes (89) }\end{array}$ & $\begin{array}{l}\text { Maternal urine during } \\
\text { pregnancy (third trimester) }\end{array}$ & 4 phthalate metabolites & 73 newborn boys & Mexico & $\begin{array}{l}\text { Negative association between total } \\
\text { phthalate levels and anopenile } \\
\text { distance. }\end{array}$ \\
\hline Huang (85) & $\begin{array}{l}\text { Maternal urine during } \\
\text { pregnancy }\end{array}$ & 5 phthalate metabolites & 33 newborn boys & Taiwan & NS \\
\hline Jensen (90) & $\begin{array}{l}\text { Maternal urine during } \\
\text { pregnancy }\end{array}$ & $\begin{array}{l}12 \text { phthalate } \\
\text { metabolites }\end{array}$ & $\begin{array}{l}245 \text { boys } 3 \text { months after the date of expected } \\
\text { delivery }\end{array}$ & Denmark & NS \\
\hline $\begin{array}{l}\text { Martino- } \\
\text { Andrade (91) }\end{array}$ & $\begin{array}{l}\text { Maternal urine collected in } \\
\text { each trimester }\end{array}$ & $\begin{array}{l}11 \text { phthalate } \\
\text { metabolites }\end{array}$ & 168 newborn boys & USA & $\begin{array}{l}\text { NS (tendency to negative } \\
\text { association between anoscrotal } \\
\text { and anopenile distance and DEHP } \\
\text { metabolite levels in the first } \\
\text { trimester) }\end{array}$ \\
\hline Suzuki (92) & $\begin{array}{l}\text { Maternal urine during } \\
\text { pregnancy }\end{array}$ & $\begin{array}{l}\text { seven phthalate } \\
\text { metabolites }\end{array}$ & 111 newborn boys & Japan & $\begin{array}{l}\text { Negative association between } \\
\text { anopenile distance/weight and } \\
\text { MEHP level. }\end{array}$ \\
\hline Swan (93) & $\begin{array}{l}\text { Maternal urine during } \\
\text { pregnancy }\end{array}$ & $\begin{array}{l}\text { nine phthalate } \\
\text { monoester metabolites }\end{array}$ & 85 boys (median age 14 months) & USA & $\begin{array}{l}\text { Levels of MEP, MBP, MBzP, MiBP } \\
\text { and their summary phthalate score } \\
\text { were negatively associated with } \\
\text { anopenile distance/weight. } \\
\text { Levels of MEP were also inversely } \\
\text { associated with anoscrotal } \\
\text { distance/weight. }\end{array}$ \\
\hline Swan (94) & $\begin{array}{l}\text { Maternal urine during } \\
\text { pregnancy }\end{array}$ & $\begin{array}{l}\text { nine phthalate } \\
\text { monoester metabolites }\end{array}$ & $\begin{array}{l}106 \text { boys aged 2-36 months (extension of } \\
\text { study by Swan et al., 2005) }\end{array}$ & USA & $\begin{array}{l}\text { Levels of MEP, MBP, MEHP, } \\
\text { MEOHP and MEHHP were } \\
\text { negatively associated with } \\
\text { anopenile distance. }\end{array}$ \\
\hline Swan (95) & First trimester urine sample & $\begin{array}{l}11 \text { phthalate } \\
\text { metabolites }\end{array}$ & 366 newborn boys & USA & $\begin{array}{l}\text { MEHP, MEOHP, MEHHP and sum } \\
\text { of DEHP metabolite levels were } \\
\text { significantly and negatively } \\
\text { associated with anoscrotal or } \\
\text { anopenile distance. }\end{array}$ \\
\hline Wenzel (96) & $\begin{array}{l}\text { Maternal urine from } \\
\text { second trimester }\end{array}$ & 8 phthalate metabolites & 171 newborn boys & USA & $\begin{array}{l}\text { Negative association between } \\
\text { MEHP and anopenile distance. } \\
\text { Positive association between molar } \\
\text { sum of DBP metabolites or MiBP } \\
\text { levels and anoscrotal distance. }\end{array}$ \\
\hline
\end{tabular}

NS, no statistically significant association.

Only statistically significant findings are shown.

(110). In the Chinese study on anogenital distance, maternal urine BPA levels showed negative associations with boys' cord blood T levels and T/estradiol (E2) -ratio (83). In the Turkish study on anogenital distance in boys, cord blood levels of BPA, phthalates and reproductive hormones were studied (79). BPA levels were positively associated with E2 levels in cord blood, but no other significant associations between chemical and reproductive hormone levels were observed (79).

The Danish-Finnish cryptorchidism study evaluated associations between EDC levels in breast milk $(106,129)$ or in placenta $(103,106,107)$ and boy's reproductive hormone levels at 3 months of age. Breast milk phthalate metabolite levels 
TABLE 2 | Case-control studies on the association between exposure to different classes of environmental EDCs (based on matrix measurements) and cryptorchidism in boys.

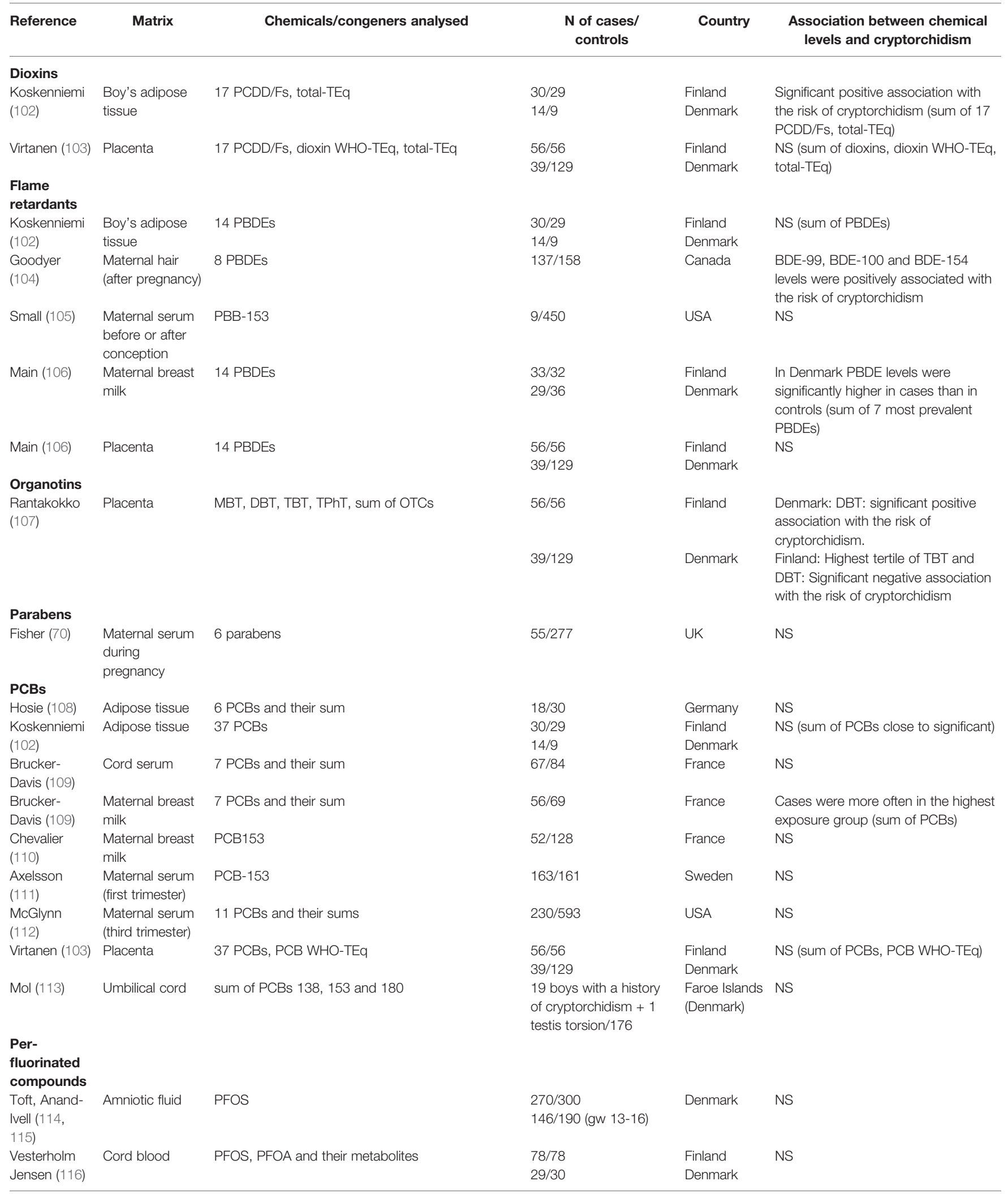


TABLE 2 | Continued

\begin{tabular}{|c|c|c|c|c|c|}
\hline Reference & Matrix & Chemicals/congeners analysed & $\begin{array}{l}\mathrm{N} \text { of cases/ } \\
\text { controls }\end{array}$ & Country & $\begin{array}{l}\text { Association between chemical } \\
\text { levels and cryptorchidism }\end{array}$ \\
\hline \multicolumn{6}{|l|}{ Pesticides } \\
\hline $\begin{array}{l}\text { Brucker- } \\
\text { Davis (109) }\end{array}$ & Cord serum & $\mathrm{DDE}$ & $67 / 84$ & France & NS \\
\hline Rouget (117) & Cord plasma & Chlordecone & $17 / 310$ & $\begin{array}{l}\text { Guadeloupe } \\
\text { (French West } \\
\text { Indies) }\end{array}$ & NS \\
\hline $\begin{array}{l}\text { Brucker- } \\
\text { Davis (109) }\end{array}$ & $\begin{array}{l}\text { Maternal breast } \\
\text { milk }\end{array}$ & DDE & $56 / 69$ & France & $\begin{array}{l}\text { Cases tended to be more often in the } \\
\text { highest exposure group (borderline } \\
\text { significance) }\end{array}$ \\
\hline $\begin{array}{l}\text { Chevalier } \\
(110)\end{array}$ & $\begin{array}{l}\text { Maternal breast } \\
\text { milk }\end{array}$ & DDE & $52 / 128$ & France & NS \\
\hline $\begin{array}{l}\text { Damgaard } \\
\text { (118) }\end{array}$ & $\begin{array}{l}\text { Maternal breast } \\
\text { milk }\end{array}$ & 27 organochlorine pesticides & $62 / 68$ & $\begin{array}{l}\text { Finland \& } \\
\text { Denmark }\end{array}$ & $\begin{array}{l}\text { Cases had significantly higher levels } \\
\text { than controls (combined analysis of } 8 \\
\text { most abundant pesticides) }\end{array}$ \\
\hline $\begin{array}{l}\text { Axelsson } \\
(111)\end{array}$ & $\begin{array}{l}\text { Maternal serum } \\
\text { (first trimester) }\end{array}$ & p,p'DDE, HCB & $165 / 165$ & Sweden & NS \\
\hline Bhatia (119) & $\begin{array}{l}\text { Maternal serum } \\
\text { during or after } \\
\text { pregnancy }\end{array}$ & DDE, DDT & $75 / 283$ & USA & NS \\
\hline $\begin{array}{l}\text { Longnecker } \\
\text { (120) }\end{array}$ & $\begin{array}{l}\text { Third trimester } \\
\text { maternal serum }\end{array}$ & DDE & $219 / 552$ & USA & NS \\
\hline Pierik (121) & $\begin{array}{l}\text { third trimester } \\
\text { maternal serum }\end{array}$ & $\begin{array}{l}\text { HCE, HCB, } \beta-H C H \text {, oxychlordane, dieldrin, p,p'- } \\
\text { DDE, p,p'-DDT }\end{array}$ & $219 / 564$ & USA & $\begin{array}{l}\text { Risk of cryptorchidism was } \\
\text { significantly increased only for } \beta-\mathrm{HCH} \\
\text { levels between } 50^{\text {th }} \text { and } 90^{\text {th }} \\
\text { percentiles }\end{array}$ \\
\hline Trabert (122) & $\begin{array}{l}\text { Third trimester } \\
\text { maternal serum }\end{array}$ & transchlordane, oxychlordane & $217 / 557$ & USA & NS \\
\hline \multicolumn{6}{|l|}{ Phenols } \\
\hline $\begin{array}{l}\text { Komarowska } \\
\text { (125) }\end{array}$ & Boy's serum & BPA & $98 / 57$ & Poland & $\begin{array}{l}\text { Total and conjugated BPA levels were } \\
\text { higher in cases }\end{array}$ \\
\hline Fénichel (126) & Cord blood & unconjugated BPA & $46 / 106$ & France & NS \\
\hline $\begin{array}{l}\text { Chevalier } \\
(110)\end{array}$ & Cord blood & BPA & $52 / 128$ & France & NS \\
\hline Fisher (70) & $\begin{array}{l}\text { Maternal serum } \\
\text { during } \\
\text { pregnancy }\end{array}$ & 9 phenols & $52 / 274$ & UK & $\begin{array}{l}\text { BPA levels were positively associated } \\
\text { with the risk of cryptorchidism }\end{array}$ \\
\hline $\begin{array}{l}\text { Chevrier } \\
\text { (127) }\end{array}$ & $\begin{array}{l}\text { Maternal urine } \\
\text { during } \\
\text { pregnancy }\end{array}$ & $\begin{array}{l}\text { BPA, benzophenone 3, triclosan, 2,4- } \\
\text { dichlorophenol, 2,5-dichlorophenol, methyl-, ethyl-, } \\
\text { propyl- and butylparaben, sum of parabens }\end{array}$ & $38 / 113$ & France & NS \\
\hline \multicolumn{6}{|l|}{ Phthalates } \\
\hline $\begin{array}{l}\text { Anand-Ivell } \\
(115)\end{array}$ & $\begin{array}{l}\text { Amniotic fluid (g } \\
\text { w 13-16) }\end{array}$ & $\begin{array}{l}\text { DEHP and DiNP metabolites } 7 \mathrm{cx}-\mathrm{MMeHP} \text { and } 5 \mathrm{cx}- \\
\text { MEPP }\end{array}$ & $146 / 190$ (gw 13-16) & Denmark & NS \\
\hline Jensen (128) & $\begin{array}{l}\text { Second- } \\
\text { trimester } \\
\text { amniotic fluid }\end{array}$ & $\begin{array}{l}\text { DEHP metabolite 5cx-MEPP, DiNP metabolite 7cx- } \\
\text { MMeHP }\end{array}$ & $270 / 300$ & Denmark & NS \\
\hline $\begin{array}{l}\text { Brucker- } \\
\text { Davis (109) }\end{array}$ & Cord serum & $\begin{array}{l}\mathrm{DBP} \\
\mathrm{mBP}\end{array}$ & $\begin{array}{l}67 / 84 \\
36 / 49\end{array}$ & France & NS \\
\hline $\begin{array}{l}\text { Brucker- } \\
\text { Davis (109) }\end{array}$ & $\begin{array}{l}\text { Maternal breast } \\
\text { milk }\end{array}$ & $\begin{array}{l}\text { DBP, } \\
\mathrm{mBP}\end{array}$ & $\begin{array}{l}56 / 69 \\
31 / 40\end{array}$ & France & NS \\
\hline $\begin{array}{l}\text { Chevalier } \\
\text { (110) }\end{array}$ & $\begin{array}{l}\text { Maternal breast } \\
\text { milk }\end{array}$ & $\mathrm{mBP}$ & $52 / 128$ & France & NS \\
\hline
\end{tabular}


TABLE 2 | Continued

\begin{tabular}{|c|c|c|c|c|c|}
\hline Reference & Matrix & Chemicals/congeners analysed & $\begin{array}{l}\mathrm{N} \text { of cases/ } \\
\text { controls }\end{array}$ & Country & $\begin{array}{l}\text { Association between chemical } \\
\text { levels and cryptorchidism }\end{array}$ \\
\hline Main (129) & $\begin{array}{l}\text { Maternal breast } \\
\text { milk }\end{array}$ & 6 phthalate monoesters & $62 / 68$ & $\begin{array}{l}\text { Finland \& } \\
\text { Denmark }\end{array}$ & NS \\
\hline Fisher (70) & $\begin{array}{l}\text { Maternal serum } \\
\text { during } \\
\text { pregnancy }\end{array}$ & 16 phthalate metabolites & $55 / 279$ & UK & No consistent association \\
\hline Swan (94) & $\begin{array}{l}\text { Maternal urine } \\
\text { during } \\
\text { pregnancy }\end{array}$ & 9 phthalate metabolites & $12 / 107$ & USA & $\begin{array}{l}\text { DEHP metabolite (especially MEHP) } \\
\text { levels were associated positively with } \\
\text { the probability of cryptorchidism }\end{array}$ \\
\hline $\begin{array}{l}\text { Chevrier } \\
(127)\end{array}$ & $\begin{array}{l}\text { Maternal urine } \\
\text { during } \\
\text { pregnancy }\end{array}$ & $\begin{array}{l}11 \text { phthalate metabolites: } \\
\text { sum of low- molecular weight phthalates, } \\
\text { sum of } 4 \text { DEHP metabolites, } \\
\text { sum of high- molecular weight phthalates }\end{array}$ & $50 / 149$ & France & NS \\
\hline \multicolumn{6}{|l|}{ Solvents } \\
\hline $\begin{array}{l}\text { Warenbourg } \\
(130)\end{array}$ & $\begin{array}{l}\text { Maternal urine } \\
\text { during } \\
\text { pregnancy }\end{array}$ & Glycol ether metabolites MAA and PhAA & $14 / 41$ & France & NS \\
\hline \multicolumn{6}{|l|}{$\begin{array}{l}\text { Combined } \\
\text { exposures }\end{array}$} \\
\hline $\begin{array}{l}\text { Brucker- } \\
\text { Davis (109) }\end{array}$ & $\begin{array}{l}\text { Maternal breast } \\
\text { milk }\end{array}$ & Composite score: DDE, sum of PCBs, mBP & $\begin{array}{l}31 / 40 \\
56 / 69\end{array}$ & France & $\begin{array}{l}\text { All exposures: NS } \\
\text { DDE + sum of PCBs: Cases tended } \\
\text { to be more often in the highest } \\
\text { exposure group (borderline } \\
\text { significance) }\end{array}$ \\
\hline $\begin{array}{l}\text { Krysiak- } \\
\text { Baltyn (131) }\end{array}$ & $\begin{array}{l}\text { Maternal breast } \\
\text { milk }\end{array}$ & $\begin{array}{l}\text { PBDEs } \\
\text { PBBs } \\
\text { phthalate metabolites } \\
\text { organochlorine pesticides } \\
\text { PCBs } \\
\text { dioxins } \\
\text { (106 chemicals included in the combined analysis) }\end{array}$ & $\begin{array}{l}29 / 36 \\
33 / 32\end{array}$ & $\begin{array}{l}\text { Denmark } \\
\text { Finland }\end{array}$ & $\begin{array}{l}\text { Only in Denmark: } \\
\text { - Higher levels in case group: PBDE } \\
119,85,75,138 \text {, OCDF } \\
\text { - Higher levels in control group: PCB } \\
18,51,33,49 \text { and } 52\end{array}$ \\
\hline
\end{tabular}

NS, no statistically significant association.

Only statistically significant findings are shown.

showed positive associations with boys' Sex hormone- binding globulin (SHBG) levels, LH levels, LH/Free $\mathrm{T}$-ratio, and negative association with boys' Free T levels (129). Breast milk PBDE levels also showed significant positive association with boys' LH levels (106). No other significant associations between PBDE levels in breast milk or placenta and boys' reproductive hormone levels at 3 months were observed (106). Placenta PCB WHO-TEq levels also showed significant positive association with boys' LH levels (only in the Finnish subjects) (103), but no significant association between placenta polychlorinated dibenzo-p-dioxins and dibenzofurans (PCDD/F) WHO-TEq levels and boys' reproductive hormone levels was observed. Associations between placenta organotin levels and boys' reproductive hormone levels differed between countries; they showed negative associations with $\mathrm{LH}$ levels and FSH/Inhibin B -ratio, and positive associations with inhibin $B$ levels in the Finnish data, but in the Danish data, organotin levels in placenta showed negative associations with T levels and T/E2 -ratio (107). These results suggest that EDC exposures may affect except fetal but also postnatal testicular function in boys.

\subsection{Hypospadias}

In hypospadias, penile development is disturbed so that the opening of urethra is situated on the ventral side of the penis, or in the scrotum or perineum (133). Hypospadias is due to failed fusion of penile urethra folds during embryonic weeks eleven to sixteen $(134,135)$. Penile development is dependent on androgens (134). Both genes and environment are thought to have a role in the etiology of hypospadias (136).

Four out of eight studies listed in Table 3 have suggested a positive association between pesticide levels and risk of hypospadias. For PCBs and phthalates, none of the few studies suggested significant positive association with risk of hypospadias. Only a few studies have evaluated so far the association between exposure to PBDEs, perfluorinated compounds, and solvents and conclusions are difficult to draw.

In the meta-analysis by Bonde et al, also associations between exposure to environmental EDCs and hypospadias was studied (132). Based on 18 risk estimates no significant association was found (132). No significant link was either found when studying association of hypospadias with specific exposures to DDE (degradation product of pesticide DDT) and PCBs (132).

Some studies evaluated cryptorchid and hypospadias cases in combination. In a Spanish study Arrebola et al. included 29 cases (16 with cryptorchidism, 12 with hypospadias, and one with both disorders) and 60 healthy controls (144). They assessed antiandrogenic activity of placenta samples using total effective xenobiotic burden of anti-androgens (TEXB-AA) as a biomarker, 
combined with a bioassay-directed fractionation protocol. They found a significant positive association between TEXB-AA levels in fraction 2 and occurrence of genital malformations (144). Another study from Spain compared placenta levels of 16 organochlorine pesticides and total effective xenoestrogen burden between a group of boys with cryptorchidism or hypospadias $(n=36)$ and a group of matched control boys $(n=109)(145)$. Cases had more often measurable level of estrogenicity due to xenoestrogens (TEXBalpha fraction) in their placenta (145). In addition, presence of five pesticides (o, $\mathrm{p}^{\prime}$-DDT, $\mathrm{p}, \mathrm{p}^{\prime}$-DDT, endosulfan- $\alpha$, lindane, and mirex) in placenta were associated with an increased risk of birth defects (cryptorchidism or hypospadias) (145). In another study, Fernandez et al. compared placenta levels of BPA, 6 benzophenones and 4 parabens in boys with genital malformations (cryptorchidism or hypospadias, $n=28)$ to those of control boys $(n=51)(146)$. The third tertiles of BPA and propylparaben (PP) levels were associated with significantly increased risk of urogenital malformations, but cryptorchidism and hypospadias were not analyzed separately (146).

Also a study from the USA evaluated cryptorchid and hypospadias cases in combination. Maternal first trimester urinary phthalate metabolite $(n=6)$ levels were not significantly associated with the risk of cryptorchidism or hypospadias $(n=5$ and $n=3$, respectively, analyzed together, and $n$ of controls $=334)(147)$. In a study from Turkey, cord blood BPA, DEHP and MEHP levels were not statistically different in patients (14 out of 100 boys) with either hypospadias, cryptorchidism or retractile testis compared to control boys (79). Another study from the USA evaluated association between in utero exposure to polybrominated biphenyls (PBBs) and cryptorchidism and hypospadias separately and combined ( $\mathrm{n}$ of all boys = 393) (105). No association was observed in the analyses (105). In the above mentioned metanalysis by Radke et al., the evidence for association between phthalate exposure and cryptorchidism or hypospadias was slight or indeterminate (51).

Small studies on risk factors of hypospadias or cryptorchidism may have limited power to find statistically significant differences. Especially hypospadias is less frequent malformation and therefore inclusion of cases may be challenging. However, some of the studies that remained negative included almost two hundred cases and thus, limited number of cases seems unlikely reason for their negative result. Differences in severity of cases, in exposure levels, in timing of the sample collection, in matrices and statistical analyses may also explain differences in results of different studies.

\subsection{Semen Quality}

Epidemiological studies have reported a global decline in semen quality, particularly in countries of Western origin. In 1992, Carlsen et al. reported a considerable global decline of mean sperm concentration from 113 million $/ \mathrm{mL}$ in 1938 to 66 million $/ \mathrm{mL}$ in 1991 (148). This finding is confirmed by later meta-analyses, including a systematic review and meta-regression analysis by Levine et al. in 2017, which showed a decline in sperm concentration globally at a rate of 0.70 million/mL/year from 1973 to 2011 (1). The decrease in sperm concentration and total sperm count was significant only among men in North America, Europe, Australia and New Zealand, which have a population of the
European descent, but not in other regions (1). The cause of deteriorating semen quality is still unclear; however, some research supports the role of EDC exposure. Here, we review epidemiological studies that investigated the association between EDC exposure and results from standard semen analysis. We include only studies that reported chemical measurements in biological matrices.

\subsubsection{Early Life Exposure}

\subsubsection{Phenols: Bisphenol A}

Hart et al. studied associations between prenatal exposure to BPA and semen quality among Western Australian Pregnancy Cohort (Raine) Study men aged 20-22 years (149). A total of 284 men had maternal serum measured for BPA levels. Serum samples were collected at $18^{\text {th }}$ and $34^{\text {th }}$ week of gestation and pooled for the statistical analysis. Maternal serum BPA levels were positively associated with sperm concentration and progressive sperm motility, but not with other semen quality parameters, after adjustment for maternal smoking, duration of sexual abstinence and the presence of varicocele (149). This result did not support the link between BPA and poor semen quality. However, the BPA level was measured in the serum, and not in the urine, which is the standard method of assessment. In addition, BPA levels at the adult age were not measured, and therefore the BPA exposure in adulthood was not determined.

\subsubsection{Polychlorinated Biphenyls, dioxins}

Some studies have reported an association between dioxins and PCBs and low semen quality $(150,151)$. Guo et al. reported that men born to mothers who had been exposed to PCBs and/or polychlorinated dibenzofurans (PCDFs) during pregnancy $(n=12)$ had higher percentage of sperm with abnormal morphology and lower percentage of total or progressive motility as compared with men who were born to non-exposed women $(n=23)$ (151). In an Italian study, 21 men who had prenatal exposure to dioxins due to a factory accident in Seveso in 1976, were observed to have lower sperm concentration, total sperm count, percentage of progressive sperm motility, and total motile sperm count than the 36 controls (150). This finding supports a link between prenatal exposure to PCBs and/or PCDFs and poor semen quality. In contrast, a study of 176 young men from a pregnancy cohort in Denmark showed that maternal serum $\Sigma$ PCB and $\Sigma$ DL-PCB levels collected at $30^{\text {th }}$ week of pregnancy were not correlated with semen quality of the sons (152).

\subsubsection{Phthalates}

Hart et al. studied association between prenatal phthalate exposure and reproductive health in adulthood in the above-mentioned Raine study (153). The study showed that pooled maternal serum levels of monoisononyl phthalate (MiNP), sums of DEHP and DiNP metabolites and the sum of high molecular weight phthalates collected at 18 and 36 weeks of pregnancy were negatively associated with testicular volume of the sons in adulthood. Maternal serum MEP levels were negatively associated with semen volume and mono-carboxy-iso-octyl phthalate (MCiOP) levels were negatively associated with progressive sperm motility (153). Axelsson et al. analyzed association between maternal serum levels of DEHPand DiNP metabolites during pregnancy and semen quality of the 
TABLE 3 | Case-control studies on the association between exposure to different classes of environmental EDCs (based on matrix measurements) and hypospadias in boys.

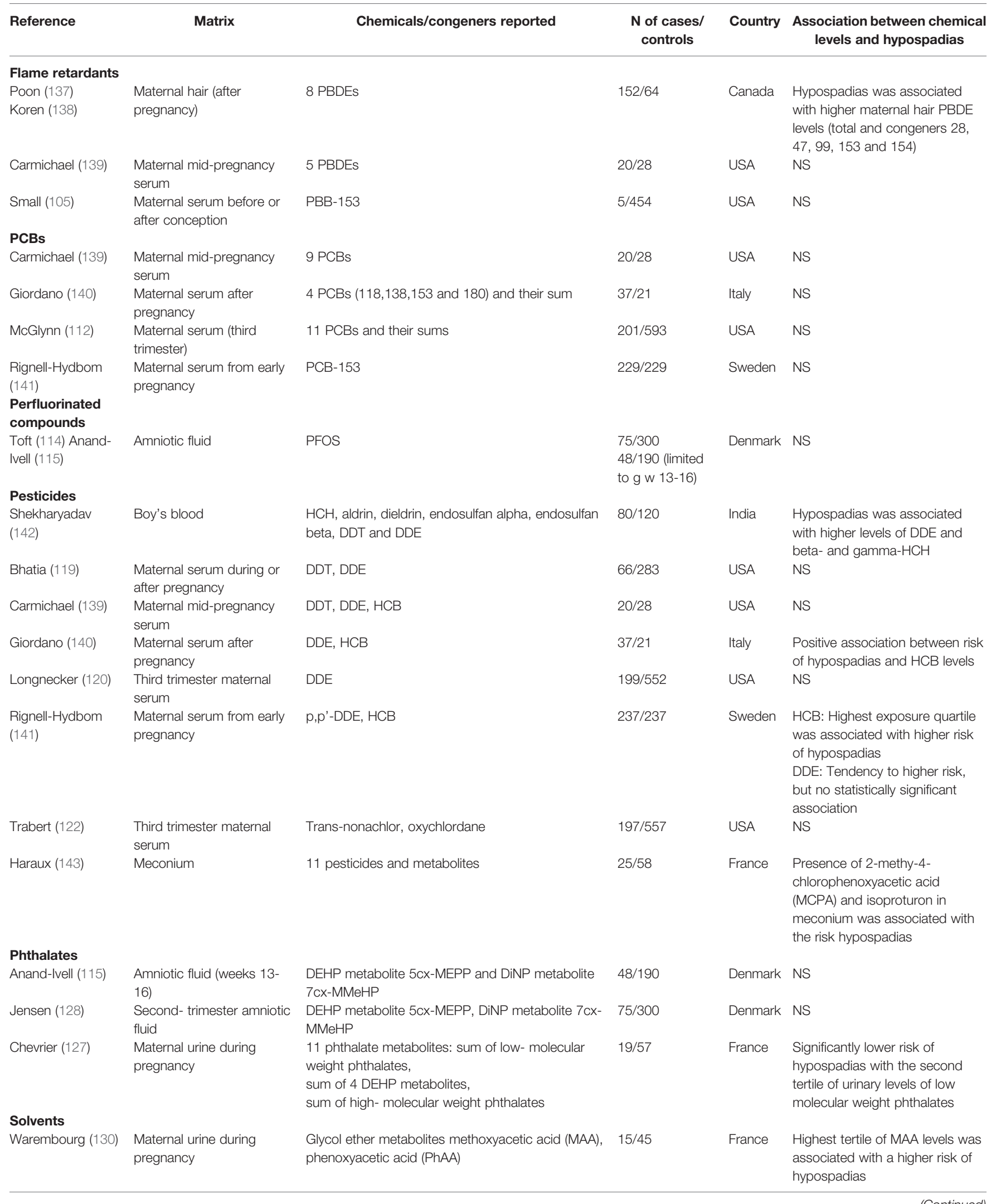


TABLE 3 | Continued

\begin{tabular}{|c|c|c|c|c|c|}
\hline Reference & Matrix & Chemicals/congeners reported & $\begin{array}{l}\mathrm{N} \text { of cases/ } \\
\text { controls }\end{array}$ & Country & $\begin{array}{l}\text { Association between chemical } \\
\text { levels and hypospadias }\end{array}$ \\
\hline \multicolumn{6}{|l|}{$\begin{array}{l}\text { Combined } \\
\text { exposures }\end{array}$} \\
\hline $\begin{array}{l}\text { Rignell-Hydbom } \\
\text { (141) }\end{array}$ & $\begin{array}{l}\text { Maternal serum from early } \\
\text { pregnancy }\end{array}$ & PCB-153, DDE, HCB & 229/229 & Sweden & NS \\
\hline
\end{tabular}

NS, no statistically significant association.

Only statistically significant findings are shown.

112 sons (154). They reported that men who had MEHHP and MCiOP exposure levels in the highest tertile had lower semen volume than those of men in the lowest exposure tertile (154). The results of these studies suggested a potential role of prenatal exposure to phthalates in determination of semen quality.

The mechanism of the association between phthalate exposure and poor semen quality in men is unclear. Studies in animals, such as rodents, demonstrated that prenatal phthalate exposure, particularly during masculinization programming window, can disrupt fetal testis development and cause a reduced androgen production. This effect can result in a variety of male reproductive disorders postnatally (63, 155-159). Fetal testis xenograft into castrate male nude mice showed that serum testosterone did not differ between vehicle and DBP-exposed hosts (52). This finding suggested that human fetal testes exposure to DBP did not impair fetal testicular testosterone production as shown in animal studies (52). However, an increased amount of multinucleated germ cells were observed in the testes exposed to DBP, indicating an adverse effect on spermatogenesis (158). Some animal studies have shown that some phthalate metabolites can act as estrogen receptor agonists by binding to estrogen receptor $\alpha$ or $\beta$ (160).

\subsubsection{Pesticides: DDT and Degradation Products}

One case-control study showed that mothers of subfertile men had significantly higher serum p,p'-DDE levels than mothers of the fertile men, which indirectly suggest the link between prenatal exposure to p,p'-DDE and male infertility (161). However, maternal serum DDE levels were measured when the men were in adult age, not during pregnancy. A pregnancy cohort study in Denmark showed that maternal level of p,p'-DDE during pregnancy was not associated with sons' semen quality (152).

\subsubsection{Perfluorinated Compounds}

A Danish pregnancy cohort study showed a negative association between maternal serum PFOA level during pregnancy and adjusted sperm concentration and total sperm count of the sons at the young adult age (162). There was no significant association between maternal serum PFOS level and semen quality of the sons (162).

In summary, there is a limited number of studies on the association between prenatal exposure to EDCs and semen quality in adulthood. Some studies demonstrated a link between prenatal EDC exposures and poor semen quality, supporting the testicular dysgenesis syndrome (TDS) hypothesis, which stated that prenatal EDC exposure can interfere with fetal testicular development and function and may result in long-term reproductive health problems $(11,163)$. For EDCs with a long half-life, e.g., persistent organic pollutants (POPs), some studies use the concurrent measurement of EDCs in men or their mothers and semen quality, assuming that these EDC levels may reflect exposure since the fetal or infancy period. However, EDC exposures may have continued postnatally, and therefore, the timing of endocrine disrupting effects cannot be clearly identified.

The studies on the association between prenatal exposure to EDCs and semen quality are summarized in Table 4. Owing to a limited number of studies and inclusion of only few birth cohort studies, no conclusions can be drawn at the moment. More birth cohort studies are needed to better illustrate the role of prenatal EDC exposures in poor semen quality.

\subsubsection{Postnatal Exposure}

There is some evidence to support a relationship between postnatal exposure to some endocrine disrupting chemicals and low semen quality. The studies are summarized in Table 5.

\subsubsection{Phenols: Bisphenol A}

To date, ten cross-sectional, one case-control and four cohort studies have evaluated the role of BPA exposure in semen quality and they have shown mixed results. All of the studies measured BPA in urine samples, except one study in which plasma and semen samples were analyzed for BPA (179). Most studies showed a negative association between urinary BPA level and sperm concentration and/or total sperm count $(164,166-168,170,174$, 179). A negative association between seminal BPA, but not plasma BPA levels, and sperm concentration, total sperm count and percentage of morphologically normal sperm was found in one study (179). Urinary BPA levels were negatively associated with sperm motility in some studies $(170,177)$.

In summary, current evidence supports the link between BPA exposure in adulthood and poor semen quality, particularly low sperm concentration, total sperm count and sperm motility.

\subsubsection{Flame Retardants}

Several studies have evaluated associations between PBDE levels in serum, hair or seminal fluid and semen quality. Most of them suggested negative associations with sperm concentration or sperm motility $(184,208,214,234,235)$. One study including men from three countries found no consistent associations across countries (236).

\subsubsection{Phthalates}

Evidence supports the link between phthalate exposure in adulthood and poor semen quality. A number of studies have shown negative associations of phthalate metabolite levels with semen quality, particularly sperm concentration $(167,186,191$, 193) and sperm motility (167, 186, 187, 189, 191, 192, 195, 197), although two studies showed a positive association between levels of some phthalate metabolites and sperm motility (187, 188). Two studies showed a negative association of phthalate 
TABLE 4 | Studies on early life endocrine disrupting chemical exposure and associations with semen quality.

\begin{tabular}{|c|c|c|c|c|c|c|c|}
\hline EDC class & Reference & Matrix & $\begin{array}{l}\text { Study } \\
\text { design }\end{array}$ & $\begin{array}{l}\text { Chemicals/ } \\
\text { congeners reported }\end{array}$ & $\mathrm{N}$ of subjects & Country & $\begin{array}{l}\text { Association between chemical } \\
\text { levels and semen quality }\end{array}$ \\
\hline \multicolumn{8}{|l|}{ Phenols: BPA } \\
\hline \multicolumn{8}{|l|}{ Dioxins } \\
\hline Axelsson 2015 & (154) & $\begin{array}{l}\text { Maternal } \\
\text { serum }\end{array}$ & $\begin{array}{l}\text { Cross- } \\
\text { sectional }\end{array}$ & $\begin{array}{l}\text { Maternal serum for } \\
\text { metabolites of DEHP } \\
\text { and DiNP }\end{array}$ & $\begin{array}{l}112 \text { adolescent males, aged } 17.5- \\
20.5 \text { y }\end{array}$ & Sweden & $\begin{array}{l}\text { Semen volume of the men with the } \\
\text { highest tertile of MEHHP and MCiOP } \\
\text { was lower than men with the lowest } \\
\text { tertile. }\end{array}$ \\
\hline \multicolumn{8}{|l|}{$\begin{array}{l}\text { PCBs and } \\
\text { pesticides } \\
\text { (p,p'-DDE) }\end{array}$} \\
\hline Vested 2014 & (152) & $\begin{array}{l}\text { Maternal } \\
\text { serum }\end{array}$ & $\begin{array}{l}\text { Birth } \\
\text { cohort }\end{array}$ & $\begin{array}{l}\text { Maternal serum for } 6 \\
\text { PCBs and p,p'-DDE } \\
\text { (pregnancy week 30) } \\
\text { Semen and blood } \\
\text { sample from each son }\end{array}$ & 176 men, aged 19-21 y & Denmark & $\begin{array}{l}\text { No associations between maternal } \\
\text { serum } \Sigma P C B s, \Sigma D L-P C B, p, p^{\prime}-D D E \\
\text { levels and semen quality of the sons }\end{array}$ \\
\hline & & & & $\begin{array}{l}\text { Semen and blood } \\
\text { sample from each son }\end{array}$ & & & Maternal serum PFOS: NS \\
\hline
\end{tabular}

NS, no statistically significant association.

Only statistically significant results are shown.

metabolite levels with semen volume $(196,198,199)$ and four studies demonstrated a negative association with percentage of morphologically normal sperm (186, 193, 195, 198). Three studies did not show any significant association with semen quality $(184,190,194)$.

\subsubsection{Organochlorine Pesticides}

Most studies on the association between p,p'-DDE levels and semen quality were conducted in the early 2000s. To date, evidence has supported an association between serum DDT or DDE levels and poor semen quality, particularly reduced sperm motility $(210,212,215,237,238)$. Some studies also reported an association with low sperm concentration $(210,211)$, abnormal morphology (210) and low semen volume $(210,211)$. However, some studies did not show an association with semen quality $(161,208,213,229)$. One study reported positive associations between semen quality and serum levels organochlorine pesticides (214). Another study did not find significant associations between peripubertal serum p,p'-DDE levels and any semen parameters in adult men (209). The role of peripubertal p,p'-DDE exposure on semen quality needs to be studied further.

Studies on the association with semen quality and levels of other organochlorine pesticides, including lindane and hexachlorobenzene, are summarized in Table 5.

\subsubsection{Other Pesticides}

In epidemiological studies, organophosphate exposure is usually assessed by detecting decreased blood, erythrocyte or plasma cholinesterase activity or detecting metabolites of organophosphates, for example dialkylphosphates (DAPs), in urine samples $(239,240)$. Possible relationship between organophosphate 
TABLE 5 | Studies on postnatal endocrine disrupting chemical exposure and associations with semen quality.

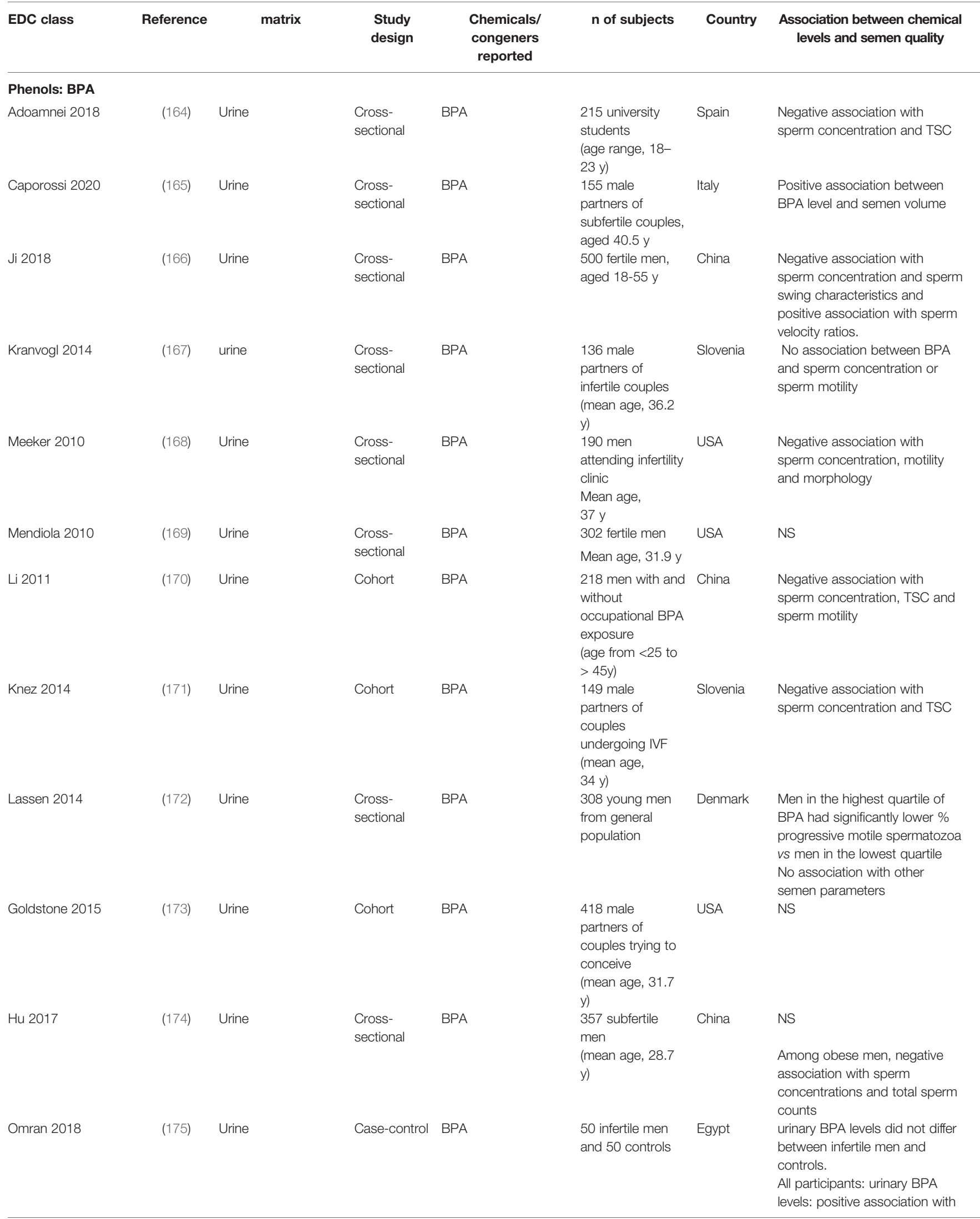


TABLE 5 | Continued

\begin{tabular}{ccccc}
\hline EDC class $\quad$ Reference & matrix & $\begin{array}{c}\text { Study } \\
\text { design }\end{array}$ & $\begin{array}{c}\text { Chemicals/ } \\
\text { congeners } \\
\text { reported }\end{array}$ & $\begin{array}{c}\text { n of subjects } \quad \text { Country Association between chemical } \\
\text { levels and semen quality }\end{array}$ \\
\hline
\end{tabular}

percentage of abnormal sperm morphology

Negative association with progressive sperm motility and

total sperm counts

Men with abnormal sperm tail morphology had higher geometric mean of BPA exposure than men with normal sperm morphology

\begin{tabular}{|c|c|c|c|}
\hline Pollard 2019 & $(176)$ & Urine & $\begin{array}{l}\text { Cross- } \\
\text { sectional }\end{array}$ \\
\hline Radwan 2018 & $(177)$ & Urine & $\begin{array}{l}\text { Cross- } \\
\text { sectional }\end{array}$ \\
\hline Vitku 2015 & $(178)$ & Plasma seminal fluid & $\begin{array}{l}\text { Cross- } \\
\text { sectional }\end{array}$ \\
\hline Vitku 2016 & (179) & $\begin{array}{l}\text { Plasma and Seminal } \\
\text { plasma }\end{array}$ & $\begin{array}{l}\text { Cross- } \\
\text { sectional }\end{array}$ \\
\hline
\end{tabular}

18-40 y with unknown subfertility

315 men, aged $<45 \mathrm{y}$, who had sperm concentration of $\geq$

15 million/ml

174 men attending the fertility center

Czech Republic

Mean age, $36 \mathrm{y}$

191 men attending infertility clinic Mean age, $36 \mathrm{y}$

Phenols: Bisphenol S (BPS) Ghayda 2019

(180) Urine

Crosssectional

BPS

158 men attending fertility center (age 18-56 y)

\section{Parabens}

Adoamnei 2018

(181) Urine

Crosssectional

BP EP

MP

PP

Jurewicz 2017

(56) Urine

Crosssectional

BP

EP

iBuP

MP
PP

Meeker 2011

(182) Urine

Cross-

sectional

Parabens sectional

\begin{abstract}
.
\end{abstract}
Smarr 2018

(183) Urine
215 university students, aged 18-23 y

315 men aged less than $45 \mathrm{y}$ who attended the infertility clinic with normal semen concentration (15300 million/mL)

190 male partners attending infertility clinic who had semen analysis results Mean age, 36.7 y

501 male partners of couples planning to become

$\begin{array}{ll}\text { Cross- } & \text { MP } \\ \text { sectional } & \text { EP } \\ & \text { PP } \\ & \text { BP }\end{array}$

Negative association with sperm motility

Slightly infertile men had higher BPA levels in plasma and seminal plasma as compared with healthy men. Negative association between seminal BPA level (but not plasma BPA) and sperm concentration and TSC Plasma BPA: NS

Seminal plasma BPA: negative association with sperm concentration, TSC and normal sperm morphology.

Men with detectable vs nondetectable BPS levels had lower semen volume, sperm concentrations, TSC and \% morphologically normal sperm

Spain NS

Poland Positive association with \% sperm with abnormal morphology Negative association with \% motility

USA

NS

$\begin{array}{ll}\text { USA } & \text { Negative association between } \\ \text { EP, BP levels and sperm count } \\ \text { Negative association between } \\ \text { EP, MP levels and \% sperm }\end{array}$

(Continued) 
TABLE 5 | Continued

\begin{tabular}{|c|c|c|c|c|c|c|c|}
\hline EDC class & Reference & matrix & $\begin{array}{l}\text { Study } \\
\text { design }\end{array}$ & $\begin{array}{l}\text { Chemicals/ } \\
\text { congeners } \\
\text { reported }\end{array}$ & $\mathrm{n}$ of subjects & Country & $\begin{array}{l}\text { Association between chemical } \\
\text { levels and semen quality }\end{array}$ \\
\hline & & & & $\begin{array}{l}\text { BzP } \\
\text { HP } \\
4-H B \\
\text { 3,4 DHB } \\
\text { OH-MeP } \\
\text { OH-EtP }\end{array}$ & $\begin{array}{l}\text { pregnant } \\
\text { Mean age }=31.8 \mathrm{y}\end{array}$ & & $\begin{array}{l}\text { motility } \\
\text { Negative association between } \\
\text { BP level and CASA sperm } \\
\text { motility parameters (average } \\
\text { path velocity, straight-line } \\
\text { velocity, curvilinear velocity, } \\
\text { beat cross frequency, \% } \\
\text { straightness and \%linearity) } \\
\text { Positive association between } \\
\text { OH-MeP level and \%normal } \\
\text { sperm (by WHO criteria) } \\
\text { Positive association between } \\
\text { OHEtP level and \%normal } \\
\text { sperm (by Strict and WHO } \\
\text { criteria) }\end{array}$ \\
\hline Axelsson 2015 & (185) & Urine & $\begin{array}{l}\text { Cross- } \\
\text { sectional }\end{array}$ & $\begin{array}{l}10 \text { phthalate } \\
\text { metabolites }\end{array}$ & $\begin{array}{l}314 \text { men from } \\
\text { general } \\
\text { population, aged } \\
17-20 \text { y }\end{array}$ & Sweden & $\begin{array}{l}\text { Negative association between } \\
\text { all the DEHP metabolites } \\
\text { (MEHP, MECPP, MEOHP, } \\
\text { MEHHP, MBP) and progressive } \\
\text { sperm motility } \\
\text { Positive association of MCiOP, } \\
\% \text { MEHP with semen volume }\end{array}$ \\
\hline Chang 2017 & (186) & $\begin{array}{l}\text { Urine and seminal } \\
\text { fluid }\end{array}$ & $\begin{array}{l}\text { Cross- } \\
\text { sectional }\end{array}$ & Phthalate metabolites & $\begin{array}{l}253 \text { male } \\
\text { partners of } \\
\text { subfertile couples } \\
37 \text { male partners } \\
\text { of fertile couples } \\
\text { Mean age: } \\
33 \text { y }\end{array}$ & Taiwan & $\begin{array}{l}\text { Urinary phthalate metabolites } \\
\text { Negative associations between: } \\
\text { - MBzP, MEHP, MEHPX and } \\
\text { sperm concentration } \\
\text { - MBzP, MEHP and sperm } \\
\text { motility } \\
\text { Seminal phthalate metabolites }\end{array}$ \\
\hline \multirow[t]{2}{*}{ Chen 2017} & (187) & Urine & Cohort & Phthalate metabolites & $\begin{array}{l}796 \text { male } \\
\text { students who } \\
\text { moved to a } \\
\text { different university } \\
\text { campuses } \\
\text { (median age: } 20 \\
\text { y) }\end{array}$ & China & $\begin{array}{l}\text { Negative associations between } \\
\text { - mEP and sperm concentration } \\
\text { - mEP, MnBP, MCPP, ¿LMWP } \\
\text { and sperm motility } \\
\text { - MnOP, MEHP, ¿HMWP and } \\
\text { morphologically normal sperm } \\
\text { Positive associations between }\end{array}$ \\
\hline & & & & & & & $\begin{array}{l}\text { - miBP, MEHP and semen } \\
\text { volume } \\
\text { - MnOP and progressive } \\
\text { motility } \\
\text { - MBzP and sperm with normal } \\
\text { morphology } \\
\text { Levels of the phthalate } \\
\text { metabolites, except MEHP, } \\
\text { decreased, while semen volume } \\
\text { and morphologically normal } \\
\text { sperm increased after } \\
\text { relocation. }\end{array}$ \\
\hline
\end{tabular}


TABLE 5 | Continued

\begin{tabular}{|c|c|c|c|c|c|c|c|}
\hline EDC class & Reference & matrix & $\begin{array}{l}\text { Study } \\
\text { design }\end{array}$ & $\begin{array}{l}\text { Chemicals/ } \\
\text { congeners } \\
\text { reported }\end{array}$ & $\mathrm{n}$ of subjects & Country & $\begin{array}{l}\text { Association between chemical } \\
\text { levels and semen quality }\end{array}$ \\
\hline Joensen 2012 & $(188)$ & $\begin{array}{l}\text { Urinary phthalate } \\
\text { metabolites }\end{array}$ & $\begin{array}{l}\text { Cross- } \\
\text { sectional }\end{array}$ & $\begin{array}{l}14 \text { phthalate } \\
\text { metabolites }\end{array}$ & $\begin{array}{l}881 \text { men } \\
\text { Median age } 19.1 \text { y }\end{array}$ & Denmark & $\begin{array}{l}\text { Men with the highest quartile of } \\
\% \text { MiNP had higher semen } \\
\text { volume and \% progressive } \\
\text { motility vs lowest quartile }\end{array}$ \\
\hline Jurewicz 2013 & $(189)$ & $\begin{array}{l}\text { Urinary phthalate } \\
\text { metabolites }\end{array}$ & $\begin{array}{l}\text { Cross- } \\
\text { sectional }\end{array}$ & $\begin{array}{l}\text { mono(2-ethyl-5OH- } \\
\text { MEHP), MEHP, DEP, } \\
\text { MEP, BBzP, MBzP, } \\
\text { DINP, MINP, DBP, } \\
\text { MBP } \\
\text { Men's serum FSH, TT } \\
\text { and E2 }\end{array}$ & $\begin{array}{l}269 \text { men } \\
\text { attending infertility } \\
\text { clinic (sperm } \\
\text { concentration } \geq \\
15 \mathrm{M} / \mathrm{mL} \text { ) }\end{array}$ & Poland & $\begin{array}{l}\text { 5OHMEHP, MEHP and MINP: } \\
\text { Negative association with } \\
\text { sperm motility }\end{array}$ \\
\hline Kranvogl 2014 & $(167)$ & Urinary phthalates & & $\begin{array}{l}9 \text { urinary phthalate } \\
\text { monoesters }\end{array}$ & $\begin{array}{l}136 \text { male } \\
\text { partners of } \\
\text { infertile couples } \\
\text { (mean age, } 36.2 \mathrm{y} \text { ) }\end{array}$ & Slovenia & $\begin{array}{l}\text { MEHP, DMP, DBP, DEHP, } \\
\text { MEOHP and sum DEHP levels } \\
\text { were negatively associated with } \\
\text { sperm concentrations. } \\
\text { MEHP, DBP, MEOHP, sum } \\
\text { DEHP levels were negatively } \\
\text { associated with sperm motility. }\end{array}$ \\
\hline Han 2014 & $(190)$ & $\begin{array}{l}\text { Urinary phthalate } \\
\text { metabolites }\end{array}$ & $\begin{array}{l}\text { Cross- } \\
\text { sectional }\end{array}$ & $\begin{array}{l}\text { Urinary levels of MBP } \\
\text { MEP } \\
\text { MEHP } \\
\text { MBzP } \\
\text { PA } \\
\text { Total PA } \\
\text { Semen analysis }\end{array}$ & $\begin{array}{l}232 \text { men from } 1 \\
\text { reproductive } \\
\text { center } \\
\text { Mean age, } \\
32 \text { y }\end{array}$ & China & $\begin{array}{l}\text { Weak association between } \\
\text { urinary MBP levels and sperm } \\
\text { concentration; men with MBP } \\
\text { levels above median were } 1.97 \\
\text { times more likely to have sperm } \\
\text { concentration below the } \\
\text { reference value. }\end{array}$ \\
\hline Pant 2008 & $(191)$ & $\begin{array}{l}\text { Seminal phthalate } \\
\text { metabolites }\end{array}$ & $\begin{array}{l}\text { Cross- } \\
\text { sectional }\end{array}$ & $\begin{array}{l}\text { Seminal levels of } \\
\text { DEP, DEHP, DBP, } \\
\text { DMP and DOP }\end{array}$ & $\begin{array}{l}300 \text { healthy men, } \\
\text { aged } 21-40 \text { y }\end{array}$ & India & $\begin{array}{l}\text { Negative association between } \\
\text { DEP, DBP, DEHP levels and } \\
\text { sperm concentration } \\
\text { Negative association between } \\
\text { DBP, DEHP and sperm motility } \\
\text { Positive association between } \\
\text { DEHP level and \% abnormal } \\
\text { sperm morphology }\end{array}$ \\
\hline Pant 2011 & (192) & Seminal fluid & $\begin{array}{l}\text { Cross- } \\
\text { sectional }\end{array}$ & DEHP and DBP & $\begin{array}{l}180 \text { healthy men, } \\
\text { aged } 21-40 \text { y }\end{array}$ & India & $\begin{array}{l}\text { Negative association between } \\
\text { DBP, DEHP levels and sperm } \\
\text { motility }\end{array}$ \\
\hline Pant 2014 & (193) & Seminal fluid & $\begin{array}{l}\text { Cross- } \\
\text { sectional }\end{array}$ & $\begin{array}{l}\text { DBP } \\
\text { DEP }\end{array}$ & $\begin{array}{l}60 \text { male partners } \\
\text { of couples } \\
\text { attending the } \\
\text { andrology } \\
\text { laboratory } \\
\text { Age } 21-40 \text { y }\end{array}$ & India & $\begin{array}{l}\text { Negative associations between } \\
\text { DEHP and sperm motility, } \\
\text { sperm concentration and } \\
\text { normal morphology }\end{array}$ \\
\hline Liu 2012 & (194) & Urine & $\begin{array}{l}\text { Cross- } \\
\text { sectional }\end{array}$ & $\begin{array}{l}6 \text { urinary phthalate } \\
\text { metabolites } \\
\text { (MMP, MEP, MBP, } \\
\text { MBzP, MEHP and } \\
\text { MEOHP) }\end{array}$ & $\begin{array}{l}97 \text { men attended } \\
\text { fertility clinic } \\
\text { (median age, } 31.5 \\
\text { y) }\end{array}$ & China & NS \\
\hline Pan 2015 & (195) & Urine & $\begin{array}{l}\text { Cross- } \\
\text { sectional }\end{array}$ & $\begin{array}{l}14 \text { phthalate } \\
\text { metabolites }\end{array}$ & $\begin{array}{l}1066 \text { men } \\
\text { (median age, } 29 \\
\text { y) }\end{array}$ & China & $\begin{array}{l}\text { Negative association between } \\
\text { MBP, MiBP and \% } \\
\text { morphologically normal sperm } \\
\text { Negative association between } \\
\% \text { MEHP and \%progressive } \\
\text { sperm motility }\end{array}$ \\
\hline Smarr 2018 & $(196)$ & Seminal fluid & $\begin{array}{l}\text { Cross- } \\
\text { sectional }\end{array}$ & phthalate metabolites & $\begin{array}{l}339 \text { male } \\
\text { partners of } \\
\text { couples }\end{array}$ & USA & $\begin{array}{l}\text { Negative associations between } \\
\mathrm{mEP}, \mathrm{mBP}, \mathrm{miBP}, \mathrm{mBz} \text { and } \\
\text { semen volume }\end{array}$ \\
\hline
\end{tabular}


TABLE 5 | Continued

\begin{tabular}{|c|c|c|c|c|c|c|c|}
\hline EDC class & Reference & matrix & $\begin{array}{l}\text { Study } \\
\text { design }\end{array}$ & $\begin{array}{l}\text { Chemicals/ } \\
\text { congeners } \\
\text { reported }\end{array}$ & $\mathrm{n}$ of subjects & Country & $\begin{array}{l}\text { Association between chemical } \\
\text { levels and semen quality }\end{array}$ \\
\hline & & & & & $\begin{array}{l}\text { discontinuing } \\
\text { contraception to } \\
\text { become } \\
\text { pregnant, mean } \\
\text { age } 31.8 \text { years }\end{array}$ & & \\
\hline Thurston 2016 & $(197)$ & Urine & $\begin{array}{l}\text { Cross- } \\
\text { sectional } \\
\text { study }\end{array}$ & $\begin{array}{l}9 \text { phthalate } \\
\text { metabolites }\end{array}$ & $\begin{array}{l}420 \text { partners of } \\
\text { pregnant women } \\
\text { Mean age, } 32 \text { y }\end{array}$ & USA & $\begin{array}{l}\text { No association between DEHP, } \\
\text { DBP, DEP, DOP levels and } \\
\text { semen quality. } \\
\text { Negative association between } \\
\text { MBzP level and sperm motility }\end{array}$ \\
\hline Wang 2016 & (198) & Seminal fluid & $\begin{array}{l}\text { Cross- } \\
\text { sectional }\end{array}$ & $\begin{array}{l}8 \text { phthalate } \\
\text { metabolites }\end{array}$ & $\begin{array}{l}\text { Male partners of } \\
\text { subfertile couples }\end{array}$ & China & $\begin{array}{l}\text { Negative associations between } \\
\text { MBP, MEHP, MEHHP, MEOHP } \\
\text { and semen volume }\end{array}$ \\
\hline & & & & & $\begin{array}{l}\text { Semen samples } \\
(n=687) \text { Blood } \\
\text { samples }(n=342)\end{array}$ & & $\begin{array}{l}\text { Positive associations between } \\
\text { MBzP and abnormal sperm } \\
\text { heads and tails. }\end{array}$ \\
\hline Specht 2014 & $(199)$ & $\begin{array}{l}\text { Urinary Secondary } \\
\text { oxidized metabolites } \\
\text { of DEHP and DiNP }\end{array}$ & $\begin{array}{l}\text { Cross- } \\
\text { sectional }\end{array}$ & $\begin{array}{l}\text { 5OH-MEHP } \\
\text { OXO-MEHP 5cx- } \\
\text { MEPP } \\
\text { 7OH-MMeOP } \\
\text { 70XO-MMeOP } \\
\text { 7cx-MMeOP }\end{array}$ & $\begin{array}{l}589 \text { male } \\
\text { partners of } \\
\text { pregnant women }\end{array}$ & $\begin{array}{l}\text { Greenland } \\
\text { Poland } \\
\text { Ukraine }\end{array}$ & $\begin{array}{l}\text { Negative associations between } \\
\text { semen volume and proxy- } \\
\text { MEHP, } 5 \mathrm{OH}-\mathrm{MEHP} \text { and } 7 \mathrm{OH}- \\
\text { MMeOP } \\
\text { Negative associations between } \\
\text { TSC and proxy-MEHP and } \\
\text { 5OH-MEHP }\end{array}$ \\
\hline \multicolumn{8}{|l|}{ Pesticides: } \\
\hline \multicolumn{8}{|l|}{ Organophosphates } \\
\hline $\begin{array}{l}\text { Miranda-Cantreras } \\
2013\end{array}$ & $(200)$ & $\begin{array}{l}\text { Erythrocyte } \\
\text { acetylcholinesterase } \\
\text { (AChE) and plasma } \\
\text { butyrylcholinesterase } \\
\text { activity }\end{array}$ & $\begin{array}{l}\text { Cross- } \\
\text { sectional }\end{array}$ & $\begin{array}{l}\text { Erythrocyte } \\
\text { acetylcholinesterase } \\
\text { (AChE) and plasma } \\
\text { butyrylcholinesterase } \\
\text { activity }\end{array}$ & $\begin{array}{l}35 \text { healthy farm } \\
\text { male workers } \\
\text { (unexpected } \\
\text { group) and } 64 \\
\text { male agricultural } \\
\text { workers (exposed } \\
\text { group) }\end{array}$ & Venezuela & $\begin{array}{l}\text { No association between } \\
\text { erythrocyte acetylcholinesterase } \\
\text { (AChE) and plasma } \\
\text { butyrylcholinesterase and } \\
\text { semen quality }\end{array}$ \\
\hline Melgarejo 2015 & $(201)$ & $\begin{array}{l}\text { Urinary levels of } 6 \\
\text { DAP metabolites }\end{array}$ & $\begin{array}{l}\text { Cross- } \\
\text { sectional }\end{array}$ & $\begin{array}{l}6 \text { urinary DAP } \\
\text { metabolites } \\
\text { (organophosphate } \\
\text { metabolites) }\end{array}$ & $\begin{array}{l}116 \text { men, } 25-38 \\
\text { years old }\end{array}$ & Spain & $\begin{array}{l}\text { Negative correlation between } \\
\text { urinary DMP levels and \% } \\
\text { sperm motility and } \\
\text { morphologically normal sperm } \\
\text { Negative association between } \\
\text { urinary levels of DMP, DMTP, } \\
\text { DMDTP, DAPs and sperm } \\
\text { concentration and TSC }\end{array}$ \\
\hline Perry 2011 & $(202)$ & Urine & Case control & 6 DAPs & $\begin{array}{l}94 \text { cases and } 95 \\
\text { controls } \\
\text { Cases had higher } \\
\text { sperm } \\
\text { concentration and } \\
\text { motility } \\
\text { Mean age, } \\
26 \text { y }\end{array}$ & China & $\begin{array}{l}\text { Cases had higher urinary DMP } \\
\text { levels vs controls }\end{array}$ \\
\hline \multicolumn{8}{|l|}{ Pesticides: } \\
\hline \multicolumn{8}{|l|}{ Pyrethroids } \\
\hline Meeker 2008 & $(203)$ & Urine & $\begin{array}{l}\text { Cross- } \\
\text { sectional }\end{array}$ & $\begin{array}{l}\text { Pyrethroid } \\
\text { metabolites: 3-PBA } \\
\text { CDCCA } \\
\text { TDCCA }\end{array}$ & $\begin{array}{l}207 \text { men } \\
\text { Mean age, } \\
36 \text { y }\end{array}$ & USA & $\begin{array}{l}\text { Men in the highest 3-PBA } \\
\text { quartile had lower sperm } \\
\text { concentration than men with } \\
\text { 3PBA of less than median. }\end{array}$ \\
\hline Ji 2011 & $(204)$ & Urine & $\begin{array}{l}\text { Cross- } \\
\text { sectional }\end{array}$ & 3-PBA & $\begin{array}{l}240 \text { men from } \\
\text { infertility clinic }\end{array}$ & China & $\begin{array}{l}\text { Negative association between } \\
\text { 3-PBA level and sperm } \\
\text { concentration }\end{array}$ \\
\hline Imai 2014 & $(205)$ & Urine & $\begin{array}{l}\text { Cross- } \\
\text { sectional }\end{array}$ & 3-PBA & $\begin{array}{l}323 \text { university } \\
\text { students }\end{array}$ & Japan & NS \\
\hline
\end{tabular}


TABLE 5 | Continued

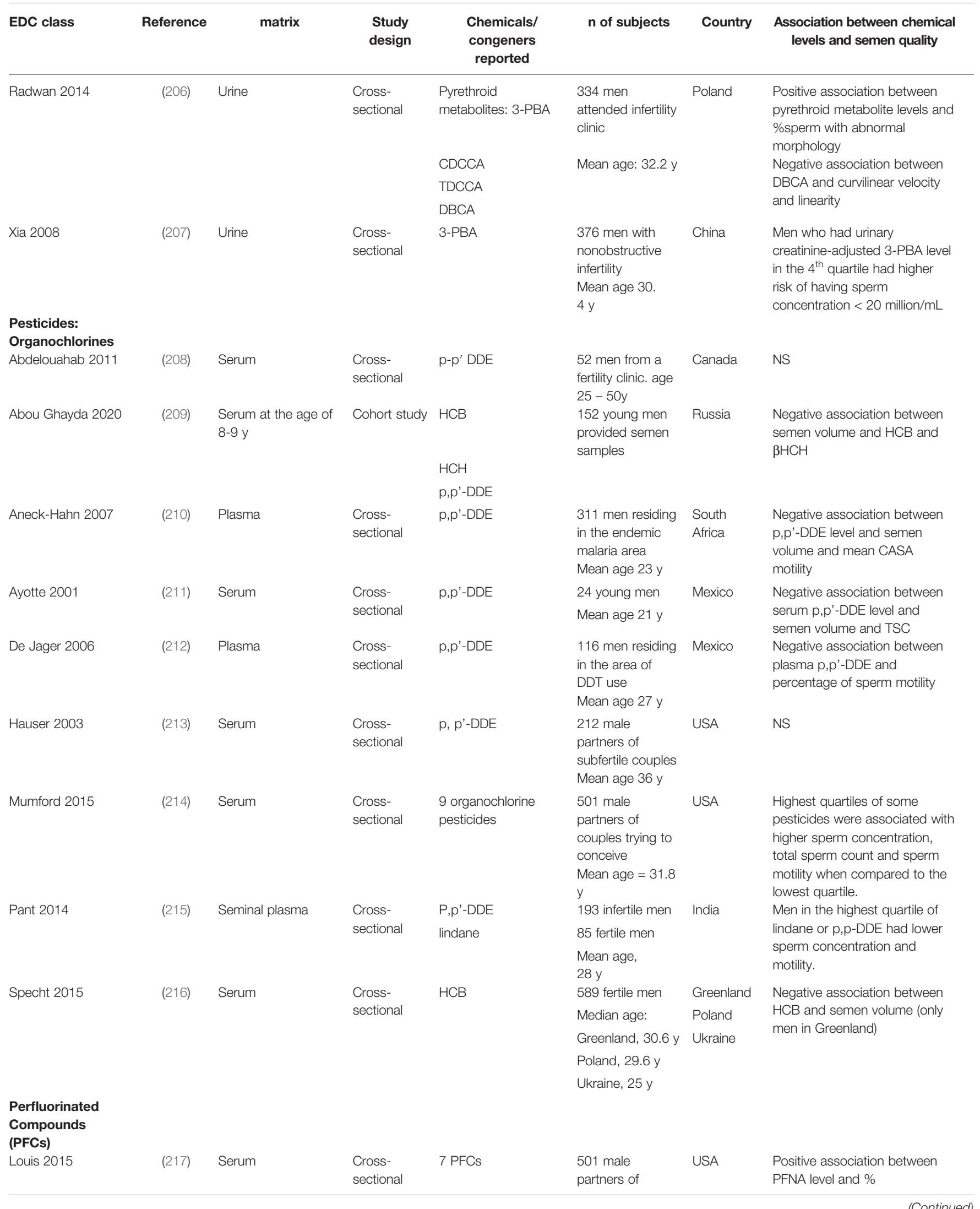


TABLE 5 | Continued

\begin{tabular}{|c|c|c|c|c|c|c|c|}
\hline EDC class & Reference & matrix & $\begin{array}{l}\text { Study } \\
\text { design }\end{array}$ & $\begin{array}{l}\text { Chemicals/ } \\
\text { congeners } \\
\text { reported }\end{array}$ & $\mathrm{n}$ of subjects & Country & $\begin{array}{l}\text { Association between chemical } \\
\text { levels and semen quality }\end{array}$ \\
\hline & & & & & \multicolumn{2}{|l|}{$\begin{array}{l}\text { couples planning } \\
\text { pregnancy } \\
\text { Mean age } \pm \mathrm{SD} \text {, } \\
31.8 \pm 4.9 \mathrm{y}\end{array}$} & $\begin{array}{l}\text { NS (semen volume, sperm } \\
\text { concentration, TSC, \%motility) }\end{array}$ \\
\hline Lewis 2015 & (219) & Serum & $\begin{array}{l}\text { Cross- } \\
\text { sectional }\end{array}$ & 4 PFASs & $\begin{array}{l}857 \text { men from } \\
\text { general } \\
\text { population } \\
\text { Age } 12-80 \text { y }\end{array}$ & USA & NS with $T$ \\
\hline Joensen 2013 & (221) & Serum PFCs & $\begin{array}{l}\text { Cross- } \\
\text { sectional }\end{array}$ & 14 PFCs & $\begin{array}{l}247 \text { healthy men } \\
\text { from general } \\
\text { population } \\
\text { Median age }=19 y\end{array}$ & Denmark & $\begin{array}{l}\text { PFHpS had negative } \\
\text { association with progressive } \\
\text { motility }\end{array}$ \\
\hline Raymer 2012 & (222) & Plasma, seminal fluid & $\begin{array}{l}\text { Cross- } \\
\text { sectional }\end{array}$ & PFOS, PFOA & $\begin{array}{l}256 \text { men came } \\
\text { for fertility } \\
\text { assessment } \\
\text { Median age }=41 \mathrm{y}\end{array}$ & USA & NS \\
\hline Toft 2012 & (223) & Serum & $\begin{array}{l}\text { Cross- } \\
\text { sectional }\end{array}$ & 4 PFCs & $\begin{array}{l}\text { Greenland, } 31.3 \text { y } \\
\text { Poland, } 29.6 \text { y } \\
\text { Ukraine, } 26.2 \text { y }\end{array}$ & $\begin{array}{l}\text { Greenland } \\
\text { Poland } \\
\text { Ukraine }\end{array}$ & $\begin{array}{l}\text { Combined } 3 \text { countries: } \\
\text { - Men who had PFOS or } \\
\text { PFHxS level in the } 3^{\text {rd }} \text { tertile had } \\
\text { lower } \% \text { morphologically normal } \\
\text { sperm than men in the } 1^{\text {st }} \text { tertile } \\
\text { - Men who had PFOA level in } \\
\text { the } 3^{\text {rd }} \text { tertile had higher } \% \\
\text { sperm motility }\end{array}$ \\
\hline \multirow[t]{2}{*}{ Dallinga 2002} & \multirow[t]{2}{*}{ (224) } & \multirow[t]{2}{*}{ Serum and semen } & \multirow[t]{2}{*}{$\begin{array}{l}\text { Cross- } \\
\text { sectional }\end{array}$} & \multirow[t]{2}{*}{$\begin{array}{l}\text { PCB 118, 138, 153, } \\
180\end{array}$} & $\begin{array}{l}65 \text { men from } \\
\text { infertility clinic } \\
\text { Mean age: }\end{array}$ & $\begin{array}{l}\text { The } \\
\text { Netherlands }\end{array}$ & \multirow{2}{*}{$\begin{array}{l}\text { Among men with good semen } \\
\text { quality: } \\
\text { Negative association between } \\
\text { serum } \Sigma \text { PCB and TSC and } \\
\text { progressive motile sperm }\end{array}$} \\
\hline & & & & & $\begin{array}{l}\text { Male factor } \\
\text { subfertility group: } \\
34.5 \text { y } \\
\text { Female factor } \\
\text { subfertility group: } \\
36.7 \text { y }\end{array}$ & & \\
\hline Hauser 2003 & (213) & Serum & $\begin{array}{l}\text { Cross- } \\
\text { sectional }\end{array}$ & 57 PCB congeners & $\begin{array}{l}212 \text { male } \\
\text { partners of } \\
\text { subfertile couples } \\
\text { Mean age } 36 \text { y }\end{array}$ & USA & $\begin{array}{l}\text { Negative association between } \\
\text { PCB-138 level and \% sperm } \\
\text { motility and \% morphologically } \\
\text { normal sperm }\end{array}$ \\
\hline $\begin{array}{l}\text { Minguez-Alarcon } \\
2017\end{array}$ & (225) & Serum & $\begin{array}{l}\text { Cohort } \\
\text { (peripubertal } \\
\text { exposure) }\end{array}$ & $\begin{array}{l}\text { Serum PCBs dioxins, } \\
\text { furans, PCBs, (age 8- } \\
9 \text { y) Semen samples } \\
\text { (age 18-19 y) }\end{array}$ & $\begin{array}{l}\text { Healthy boys, } \\
\text { aged } 8-9 \text { y } \\
(n=516) \text { and } 18- \\
19 \text { y }(n=133)\end{array}$ & Russia & $\begin{array}{l}\text { Serum TCDD and PCDD TEQs: } \\
\text { Negative association with } \\
\text { sperm concentration, TSC, total } \\
\text { motile sperm count } \\
\text { Serum PCBs, furans and total } \\
\text { TEQs: no association }\end{array}$ \\
\hline Mumford 2015 & (214) & Serum & $\begin{array}{l}\text { Cross- } \\
\text { sectional }\end{array}$ & 36 PCB congeners & $\begin{array}{l}501 \text { male } \\
\text { partners of }\end{array}$ & USA & $\begin{array}{l}\text { Highest quartiles of some } \\
\text { congeners were associated } \\
\text { with higher volume, total sperm }\end{array}$ \\
\hline
\end{tabular}


TABLE 5 | Continued

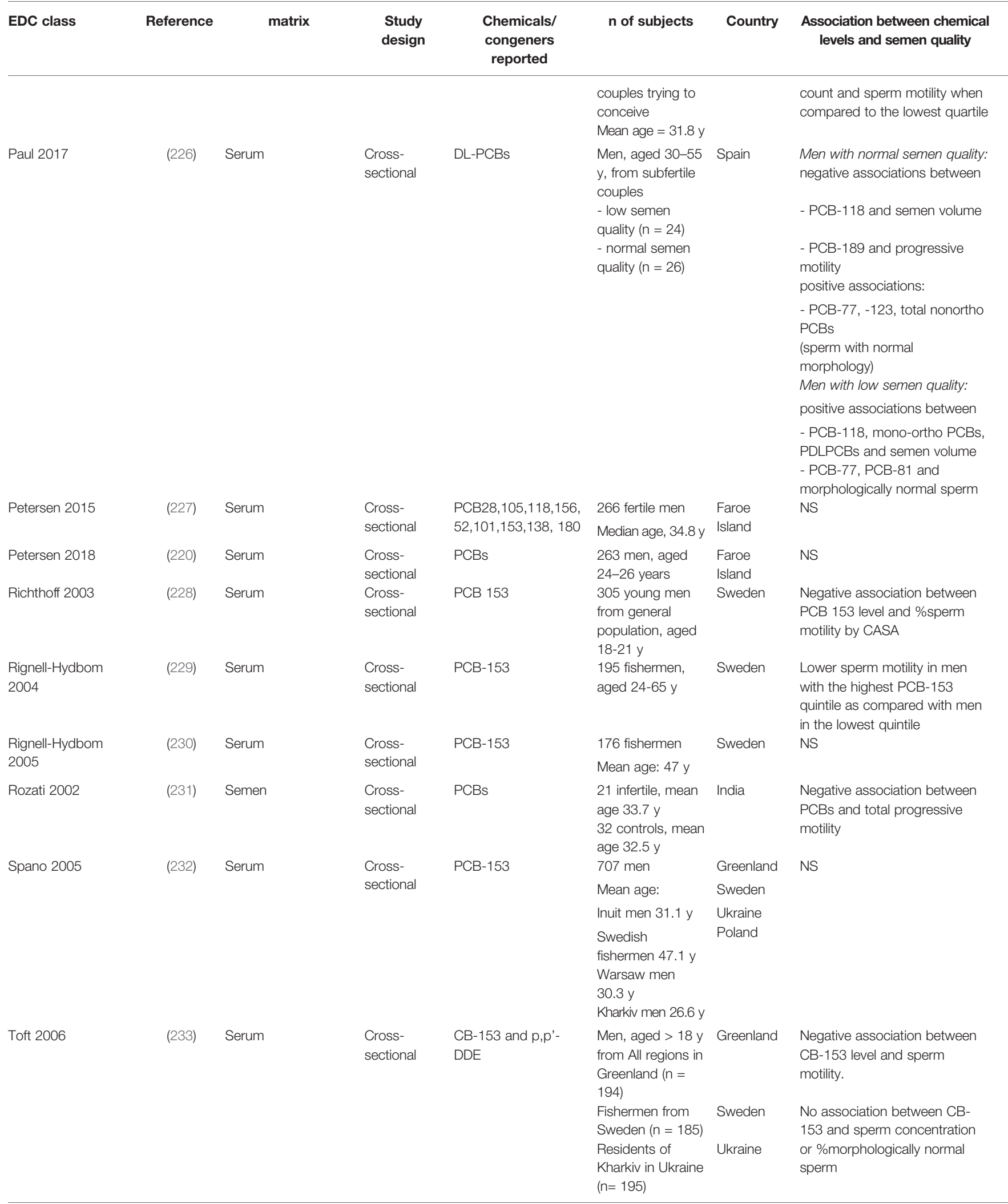


TABLE 5 | Continued

\begin{tabular}{|c|c|c|c|c|c|c|c|}
\hline EDC class & Reference & matrix & $\begin{array}{l}\text { Study } \\
\text { design }\end{array}$ & $\begin{array}{l}\text { Chemicals/ } \\
\text { congeners } \\
\text { reported }\end{array}$ & $\mathrm{n}$ of subjects & Country & $\begin{array}{l}\text { Association between chemical } \\
\text { levels and semen quality }\end{array}$ \\
\hline & & & & & $\begin{array}{l}\text { Residents of } \\
\text { Warsaw in Poland } \\
(n=189)\end{array}$ & Poland & \\
\hline Vitku 2016 & $(179)$ & $\begin{array}{l}\text { Plasma and Seminal } \\
\text { plasma }\end{array}$ & $\begin{array}{l}\text { Cross- } \\
\text { sectional }\end{array}$ & $\begin{array}{l}6 \text { PCB congeners } \\
\text { (PCB 28, 101, 118, } \\
138,153,180)\end{array}$ & $\begin{array}{l}191 \text { men } \\
\text { attended infertility } \\
\text { clinic } \\
\text { Mean age } 35 \text { y }\end{array}$ & Czech & $\begin{array}{l}\text { ¿PCBs (PCB 180, }-153,-118 \\
\text { and -138) had positive } \\
\text { association with sperm } \\
\text { concentration and TSC }\end{array}$ \\
\hline \multicolumn{8}{|l|}{ Flame retardants } \\
\hline Albert 2018 & $(184)$ & Hair & $\begin{array}{l}\text { Cross- } \\
\text { sectional }\end{array}$ & 8 PBDE congeners & $\begin{array}{l}153 \text { healthy men, } \\
\text { aged } 18-41 \text { y }\end{array}$ & Canada & $\begin{array}{l}\text { NS (tendency to negative } \\
\text { association with sperm } \\
\text { concentration and sperm } \\
\text { motility) }\end{array}$ \\
\hline \multirow[t]{2}{*}{ Yu 2018} & (234) & Seminal fluid & $\begin{array}{l}\text { Cross- } \\
\text { sectional }\end{array}$ & PBDEs & $\begin{array}{l}\text { Cases: men aged } \\
20-50 \text { y residing } \\
\text { at an e-waste } \\
\text { dismantling } \\
\text { workshop }(n=32)\end{array}$ & China & $\begin{array}{l}\text { TSC, progressive motility, and } \\
\text { total motile sperm were lower in } \\
\text { cases than in controls. }\end{array}$ \\
\hline & & & & & $\begin{array}{l}\text { Controls: men } \\
\text { aged } 24-46 \text { y } \\
(n=25)\end{array}$ & & $\begin{array}{l}\text { Negative associations between } \\
\text { seminal BDE-47 and sperm } \\
\text { concentration and TSC }\end{array}$ \\
\hline Abdelouahab 2011 & $(208)$ & Serum & $\begin{array}{l}\text { Cross- } \\
\text { sectional }\end{array}$ & $\begin{array}{l}\text { BDE-47, BDE-99, } \\
\text { BDE-100, BDE-153 }\end{array}$ & $\begin{array}{l}52 \text { men from a } \\
\text { fertility clinic. Age } \\
25-50 y\end{array}$ & Canada & $\begin{array}{l}\text { Negative association with } \\
\text { sperm motility }\end{array}$ \\
\hline Akutsu 2008 & (235) & Serum & $\begin{array}{l}\text { Cross- } \\
\text { sectional }\end{array}$ & 29 PBDE congeners & $\begin{array}{l}10 \text { men, aged } 18 \\
-21 y\end{array}$ & Japan & $\begin{array}{l}\text { HxBDE-153 showed significant } \\
\text { negative association with sperm } \\
\text { concentration }\end{array}$ \\
\hline Mumford 2015 & $(214)$ & Serum & $\begin{array}{l}\text { Cross- } \\
\text { sectional }\end{array}$ & $\begin{array}{l}10 \text { PBDE congeners } \\
\text { and PBB-153 }\end{array}$ & $\begin{array}{l}501 \text { male } \\
\text { partners of } \\
\text { couples trying to } \\
\text { conceive } \\
\text { Mean age = } 31.8 \mathrm{y}\end{array}$ & USA & $\begin{array}{l}\text { Highest quartiles of some } \\
\text { congeners were associated } \\
\text { with lower sperm motility and } \\
\text { higher sperm concentration and } \\
\% \text { of abnormal morphology } \\
\text { when compared to the lowest } \\
\text { quartile }\end{array}$ \\
\hline \multirow[t]{4}{*}{ Toft 2014} & $(236)$ & Serum & $\begin{array}{l}\text { Cross- } \\
\text { sectional }\end{array}$ & $\begin{array}{l}\text { BDE-28, 47, 99,100, } \\
\text { 153, } 154 \text { and 183, } \\
\text { and } B B-153\end{array}$ & $\begin{array}{l}299 \text { partners of } \\
\text { pregnant women } \\
\text { Median age: }\end{array}$ & $\begin{array}{l}\text { Greenland, } \\
\text { Poland and } \\
\text { Ukraine }\end{array}$ & $\begin{array}{l}\text { BDE-47 and BDE 153: NS (no } \\
\text { consistent associations across } \\
\text { countries) }\end{array}$ \\
\hline & & & & & Greenland, 32.1 y & & \\
\hline & & & & & Poland, 29.6 y & & \\
\hline & & & & & Ukraine, 26.1 y & & \\
\hline
\end{tabular}

Only statistically significant findings have been shown.

Only studies reporting standard semen quality parameters are included.

NS, no statistically significant association.

exposure and low semen quality has been shown (200-202, 241), however the number of studies are limited. Three studies showed a negative association between the level of 3-phenoxybenzoic acid (3PBA), which is a metabolite of pyrethroids, and sperm concentration $(203,204,207)$. However, one study did not report such a finding (205). One study showed that higher pyrethroid metabolite levels were associated with higher percentage of sperm with abnormal morphology, lower sperm concentration, and increasing rate of abnormal computer-assisted semen analysis (CASA) parameters, including lower curvilinear velocity and linearity (206).

\subsubsection{Parabens}

Four cross-sectional studies investigated relationship between urinary paraben levels and semen quality and showed mixed results $(56,181-183)$. One study showed a significant positive association between urinary level of butylparaben (BP) and percentage of morphologically abnormal sperm and a negative association with percentage of sperm motility (56). Another study showed that urinary ethyl paraben (EP) and BP levels were negatively associated with sperm concentrations and urinary BP, EP and methyl paraben (MP) levels were negatively associated with percentage of sperm motility parameters by CASA. Levels of hydroxylated metabolites methyl-protocatechuic acid $(\mathrm{OH}-\mathrm{Me}) \mathrm{P}$ and ethylprotocatechuic acid (OH-EtP) were positively associated with percentage of morphologically normal sperm (183). However, two studies did not show any significant associations between paraben level and semen quality (181, 
182). To summarize, there is limited amount of evidence suggesting a link between paraben exposure and semen quality.

\subsubsection{Perfluorinated Compounds}

To date, four cross-sectional studies - two from Denmark, one from Faroe Island, and one from the USA - have examined the relationship between PFC exposure in adulthood and semen quality. Three studies did not find any significant associations between serum PFC levels and semen quality (220-222). Only one study from Denmark showed lower percentage of morphologically normal sperm in men who had high combined PFOA and PFOS levels as compared with those who had low levels (218).

\subsubsection{Polychlorinated Biphenyls}

Several cross-sectional studies have demonstrated a link between PCB exposure, particularly PCB-153, in adulthood, and low semen quality $(213,224,226,228,229,231,233,242,243)$, particularly low sperm motility $(213,224,226,228,229,231,233)$. In contrast, one Chinese study showed an association with higher progressive sperm motility (238). In addition, this study also showed a positive association between sum of seminal dioxin-like PCB levels and semen volume, a negative association between seminal PCB-66, PCB-105 and sperm concentration, and a positive association between seminal PCB-44 and sperm concentration (238). A study on male partners of couples trying to conceive also reported positive associations between semen quality and serum levels of some PCB congeners (214). Whereas a study on men from a fertility clinic found no significant association between semen quality and serum PCB levels (208).

\subsection{Reproductive Hormone Levels 2.5.1 Early Life Exposure}

A limited number of studies have investigated the association between prenatal exposure to EDCs and reproductive hormone levels in adult men. These studies are summarized in Table 6.

\subsubsection{Phenols: Bisphenol A}

To date, there is no evidence supporting the relationship between maternal BPA exposure and reproductive hormone levels of the sons at the adult age. The pregnancy cohort in Western Australia 'Raine study' found no association of maternal serum BPA with hypothalamic-pituitary-gonadal (HPG) hormone levels of the sons (149).

\subsubsection{Phthalates}

The Australian Raine study found that serum total testosterone levels of the sons at a young adult age were positively associated with maternal serum levels of serum phthalate metabolites during pregnancy, including MEHP, MiNP, the sum of DEHP and DiNP metabolites, and the sum of high molecular weight phthalates after adjustment for BMI (153). In addition, there was a positive association between maternal serum MiNP levels and FSH levels of the men and between maternal serum DEHP levels and serum LH levels of the men. A negative association between maternal MEHP level and serum LH to testosterone ratio in adult men was also observed. No association between maternal levels of phthalate metabolites during pregnancy and serum inhibin B or estradiol levels in adult men was found (153).
A study in 112 males, aged 17.5-20.5 years, and paired maternal serum samples collected at a mean of 12 weeks of gestation in Sweden demonstrated positive associations between maternal serum levels of MCiOP and mono-(oxo-iso-nonyl) phthalate (MOiNP) and FSH levels of the sons, and between maternal serum levels of two DiNP metabolites [mono-hydroxy-iso-nonyl phthalate (MHiNP) and MOiNP] and LH levels of the sons (154). DEHP metabolite levels in maternal serum were positively associated with total and free testosterone levels of the sons (154).

Results from these two studies suggested the potential longterm effects of prenatal phthalate exposure on the hypothalamicpituitary-gonadal axis. However, more studies are needed to corroborate or refute these findings.

\subsubsection{Dioxins}

Mocarelli et al. studied reproductive hormone levels of sons born to mothers who were exposed to dioxins during pregnancy due to an accident in Seveso, Italy, and compared them with hormone levels of sons born to mothers who had background exposure. Among breastfed group, 21 sons with maternal dioxin exposure had higher FSH and lower inhibin B levels than 36 sons with maternal background exposure (150). Among the maternal dioxin exposure group, breastfed sons $(n=21)$ had higher FSH and lower inhibin B levels than formula-fed sons $(\mathrm{n}=18)$ (150). Among breastfed group, sons born to the exposed mothers had lower semen quality than sons born to the non-exposed mothers. These results suggest that in-utero and/or neonatal exposure to dioxins have a role in germ cell defects.

\subsubsection{PCBs, Pesticides ( $\left.p, p^{\prime}-D D E\right)$, and Perfluorinated Compounds}

A birth-cohort study in Denmark showed that maternal serum PFOA level at $30^{\text {th }}$ week of pregnancy was positively associated with serum FSH and LH level of the sons at the age of 19-21 years (162). There was no significant association between maternal serum PFOS, PCBs, p, p'DDE levels and serum levels of FSH, LH, testosterone, inhibin B, estradiol or SHBG in the adult sons $(152,162)$.

\subsubsection{Postnatal Exposure}

Several studies have investigated the HPG axis hormone levels in adult men in relation to EDC exposure. Many studies examined the association of EDC exposure with testosterone levels. Some studies also evaluated pituitary FSH and LH levels. Only a small number of studies evaluated levels of inhibin B, which is Sertoli cell and germ cell biomarker. Results of the studies are summarized in Table 7.

\subsubsection{Phenols: Bisphenol A}

Associations between BPA levels and reproductive hormone levels were examined in 14 cross-sectional studies (Table 7), and they showed variable results. Eleven studies analyzed BPA level in urine samples, two studies analyzed BPA level in serum $(252,253)$, and one study measured BPA level in plasma and seminal plasma (179). An association between BPA level and serum testosterone level was not significant in most studies (164, $169,179,247-253)$. Two studies have demonstrated a positive association between BPA level and serum total testosterone level $(172,244)$ and only one study showed a negative association (246). Some studies did not show significant association between 
TABLE 6 | Summary of studies that evaluated early life EDC exposure and adult reproductive hormone levels.

\begin{tabular}{|c|c|c|c|c|c|c|c|}
\hline EDC class & Reference & Matrix & $\begin{array}{l}\text { Study } \\
\text { design }\end{array}$ & $\begin{array}{l}\text { Chemicals/congeners } \\
\text { reported }\end{array}$ & $\mathrm{N}$ of subjects & Country & $\begin{array}{l}\text { Association between chemical levels } \\
\text { and reproductive hormone levels }\end{array}$ \\
\hline \multicolumn{8}{|l|}{ Phenols: BPA } \\
\hline \multicolumn{8}{|l|}{ Phthalates } \\
\hline Axelsson 2015 & (154) & $\begin{array}{l}\text { Maternal } \\
\text { serum }\end{array}$ & $\begin{array}{l}\text { Cross- } \\
\text { sectional }\end{array}$ & $\begin{array}{l}\text { Maternal serum (mean } 12 \\
\text { weeks of gestation) for } \\
\text { metabolites of DEHP and } \\
\text { DiNP }\end{array}$ & $\begin{array}{l}112 \text { adolescent males, } \\
\text { aged } 17.5-20.5 \text { y }\end{array}$ & Sweden & $\begin{array}{l}\text { Highest tertile of MCiOP had higher } \\
\text { FSH vs lowest tertile } \\
\text { MCiOP and MOiNP: positively } \\
\text { associated with FSH } \\
\text { MHiNP and MOiNP: positively } \\
\text { associated with LH }\end{array}$ \\
\hline Hart 2018 & (153) & $\begin{array}{l}\text { Maternal } \\
\text { serum }\end{array}$ & Cohort & $\begin{array}{l}\text { Maternal serum (pooled at } \\
18 \text { and } 34 \text { GW) for } 32 \\
\text { phthalate metabolites } \\
\text { Serum for hormones of } \\
\text { sons }\end{array}$ & $\begin{array}{l}\text { Men in the birth cohort } \\
\text { study (185 men had serum } \\
\text { hormone measured and } \\
\text { had maternal phthalate } \\
\text { results), aged } 20-22 \text { y }\end{array}$ & Australia & $\begin{array}{l}T \text { at the age of } 20-22 \text { y: positively } \\
\text { associated with MEHP, MiNP, } \\
\Sigma D E H P m, \Sigma D i N P m, \Sigma H M W \text { phth.m and } \\
\sum D E H P m+\text { DiNPm (adjusted for BMI) } \\
\text { NS (when adjusted for multiple } \\
\text { comparisons) } \\
\text { Positive association between MiNP level } \\
\text { and FSH (adjusted for BMI) } \\
\text { Negative association between MEHP } \\
\text { level and LH:T ratio (adjusted for BMI) } \\
\text { Positive association between } \Sigma \text { DEHPm } \\
\text { and LH levels } \\
\text { No association between prenatal } \\
\text { phthalate metabolite levels and adult } \\
\text { male serum inhibin B, E1 or E2 levels }\end{array}$ \\
\hline \multicolumn{8}{|r|}{ the } \\
\hline Mocarelli 2011 & (150) & $\begin{array}{l}\text { Maternal } \\
\text { serum }\end{array}$ & Cohort & Maternal serum TCDD & $\begin{array}{l}39 \text { men born to mothers } \\
\text { who exposed to dioxin } \\
\text { following the accident in } \\
\text { Seveso, Italy (mean age, } \\
22.5 \text { y) vs } 58 \text { comparisons } \\
\text { (mean age }=24.6 \text { y) }\end{array}$ & Italy & $\begin{array}{l}\text { Higher FSH and lower inhibin B in the } \\
\text { breast-fed exposed group vs breast-fed } \\
\text { comparisons } \\
\text { Higher FSH and lower inhibin B in the } \\
\text { breast-fed exposed group vs formula- } \\
\text { fed exposed group }\end{array}$ \\
\hline \multicolumn{8}{|l|}{$\begin{array}{l}\text { Perfluorinated } \\
\text { compounds }\end{array}$} \\
\hline \multicolumn{8}{|l|}{$\begin{array}{l}\text { PCBs and } p \text {, } \\
\text { p'-DDE }\end{array}$} \\
\hline Vested 2014 & (152) & $\begin{array}{l}\text { Maternal } \\
\text { serum }\end{array}$ & $\begin{array}{l}\text { Birth } \\
\text { cohort }\end{array}$ & $\begin{array}{l}\text { Maternal serum for } 6 \\
\text { PCBs and p,p'-DDE (at } \\
\text { pregnancy week 30) }\end{array}$ & $\begin{array}{l}176 \text { men at the age of } 19- \\
21 \mathrm{y}\end{array}$ & Denmark & NS \\
\hline
\end{tabular}

NS, no statistically significant association.

Only statistically significant findings are shown.

BPA and LH levels $(169,245,250,251)$, whereas some showed a significant positive association $(164,172,248)$. Studies on the relationship between BPA and FSH levels have also shown mixed results - most studies did not show any significant correlation $(164,169,172,247,250,252)$, while two studies showed a positive association $(248,251)$. Some studies also evaluated inhibin B level, which showed no significant association with BPA level $(164,169,172,252,253)$.

\subsubsection{Flame Retardants}

Several studies have evaluated associations between flame retardant levels in serum or hair and reproductive hormone levels in adult men. Two studies suggested a positive association with testosterone levels $(254,256)$. One small study suggested a negative association with inhibin B levels (255). In contrast, two large studies found no consistent or significant association between reproductive hormone levels and flame retardant levels $(184,236)$.

\subsubsection{Phthalates}

Experimental studies showed that phthalates had a variety of effects on the HPG axis function in male rats, including low FSH and $\mathrm{LH}$ levels as well as high or low $\mathrm{GnRH}$ and testosterone levels [reviewed in Hlisníková 2020 (281)]. Phthalates can also disturb testicular hormone production by altering steroidogenic enzyme activity, including decreased or increased levels of CYP11a1, Hsd3b, Hsd17b enzymes and decreased levels of CYP17a1 enzyme, changes in steroidogenic acute regulatory protein (StAR) amount (281). 
TABLE 7 | Summary of studies that evaluated postnatal EDC exposure and adult reproductive hormone levels.

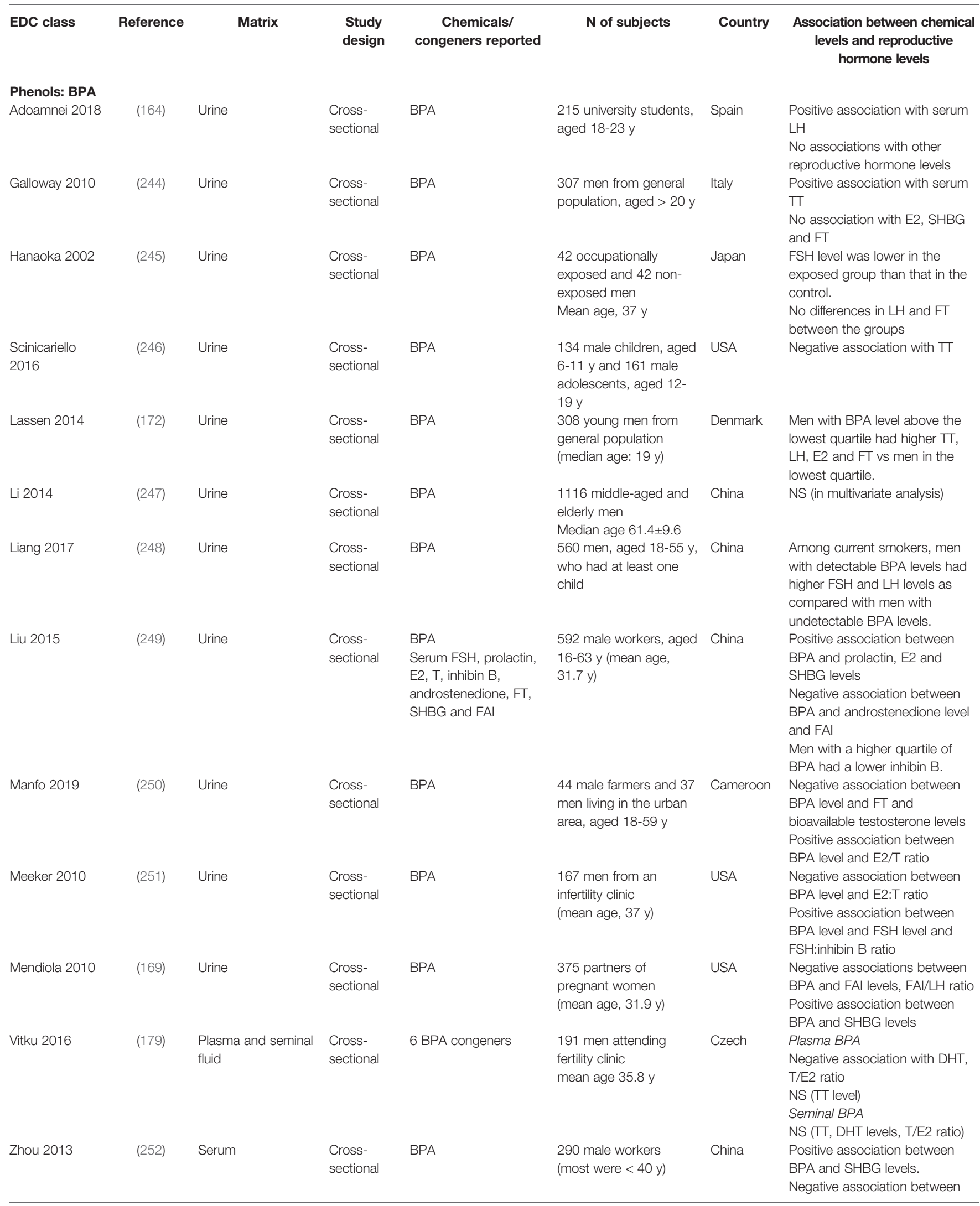


TABLE 7 | Continued

\begin{tabular}{|c|c|c|c|c|c|c|c|}
\hline EDC class & Reference & Matrix & $\begin{array}{l}\text { Study } \\
\text { design }\end{array}$ & $\begin{array}{l}\text { Chemicals/ } \\
\text { congeners reported }\end{array}$ & $\mathrm{N}$ of subjects & Country & $\begin{array}{c}\text { Association between chemical } \\
\text { levels and reproductive } \\
\text { hormone levels }\end{array}$ \\
\hline Zhuang 2015 & (253) & Serum & $\begin{array}{l}\text { Cross- } \\
\text { sectional }\end{array}$ & $\begin{array}{l}\text { Serum BPA } \\
\text { Serum SHBG, T, } \\
\text { inhibin B, } \\
\text { androstenedione }\end{array}$ & $\begin{array}{l}281 \text { male workers } \\
\text { exposed to BPA (mean } \\
\text { age } 34.1 \text { y) } \\
278 \text { males not exposed } \\
\text { to BPA (mean age } 32.8 \mathrm{y} \text { ) }\end{array}$ & China & $\begin{array}{l}\text { Men exposed vs not exposed to } \\
\text { BPA: no difference in SHBG, } \Pi \text {, } \\
\text { inhibin B and androstenedione } \\
\text { Men exposed to BPA of }>5 y \\
\text { compared to exposure }<5 y \text { : } \\
\text { higher serum BPA and SHBG } \\
\text { but lower serum } \\
\text { androstenedione. } \\
\text { BPA level of }>18.75 \mathrm{ng} / \mathrm{mL} \text { was } \\
\text { associated with lower } \\
\text { androstenedione level and higher } \\
\text { SHBG level compared with } \\
\text { groups having lower BPA level. }\end{array}$ \\
\hline Albert 2018 & (184) & Hair & $\begin{array}{l}\text { Cross- } \\
\text { sectional }\end{array}$ & 8 PBDE congeners & $\begin{array}{l}153 \text { healthy men, aged } \\
18-41 \text { y) }\end{array}$ & Canada & NS \\
\hline Guo 2018 & (254) & Serum & $\begin{array}{l}\text { Cross- } \\
\text { sectional }\end{array}$ & $\begin{array}{l}\text { sum of } 13 \text { PBDE } \\
\text { congeners } \\
\text { Sum of } 8 \text { new flame } \\
\text { retardants }\end{array}$ & $\begin{array}{l}26 \text { exposed men } \\
\text { (residents from an e- } \\
\text { waste dismantling } \\
\text { region) and } 25 \text { non- } \\
\text { exposed men } \\
\text { Age } 46-65 \text { y }\end{array}$ & China & $\begin{array}{l}\text { Sums of flame retardants } \\
\text { showed positive association with } \\
\text { T levels and negative association } \\
\text { with FSH levels (the latter finding } \\
\text { only with the sum of new flame } \\
\text { retardants). } \\
\text { No significant association with } \\
\text { LH levels. }\end{array}$ \\
\hline Makey 2016 & (255) & Serum & $\begin{array}{l}\text { Cross- } \\
\text { sectional } \\
\text { and } \\
\text { longitudinal }\end{array}$ & 11 PBDE congeners & $\begin{array}{l}27 \text { healthy adult men } \\
\text { Mean age }= \\
41 \mathrm{y}\end{array}$ & USA & $\begin{array}{l}\text { Negative association with inhibin } \\
\text { B, positive association with FSH } \\
\text { (in men aged } 40 \text { years or above). } \\
\text { NS (with T,, Free T, prolactin, } \\
\text { LH, FAl and SHBG) }\end{array}$ \\
\hline \multicolumn{8}{|l|}{ PCBs } \\
\hline Vitku 2016 & (179) & Plasma & $\begin{array}{l}\text { Cross- } \\
\text { sectional }\end{array}$ & $\begin{array}{l}6 \text { PCB } \\
\text { congeners }\end{array}$ & $\begin{array}{l}191 \text { men attending } \\
\text { fertility clinic } \\
\text { mean age }(S D)=35.8 \pm \\
5.6 \text { y }\end{array}$ & Czech & $\begin{array}{l}\text { Sum of PCB congeners: } \\
\text { negative association with plasma } \\
\Pi, F, \text { FAl, DHT levels }\end{array}$ \\
\hline $\begin{array}{l}\text { Giwercman } \\
2006\end{array}$ & (257) & Serum & $\begin{array}{l}\text { Cross- } \\
\text { sectional }\end{array}$ & CB-153 & $\begin{array}{l}\text { Swedish fishermen } \\
\text { ( } \mathrm{n}=184 \text {, mean age } 47 \mathrm{y}) \\
\text { Greenland } \\
(\mathrm{n}=258 \text {, mean age } 31 \mathrm{y}) \\
\text { Poland } \\
(\mathrm{n}=113 \text {, mean age } 31 \mathrm{y}) \\
\text { Kharkiv, Ukraine } \\
(\mathrm{n}=194, \text { mean age } 27 \mathrm{y})\end{array}$ & $\begin{array}{l}\text { Sweden } \\
\text { Greenland } \\
\text { Poland } \\
\text { Ukraine }\end{array}$ & $\begin{array}{l}\text { Swedish fishermen: NS } \\
\text { Greenland: positive association } \\
\text { between CB-153 and LH levels } \\
\text { Poland: lower FI in the third } \\
\text { highest CB-153 group as } \\
\text { compared with the lowest group } \\
\text { Ukraine: positive association } \\
\text { between CB-153 and SHBG } \\
\text { and LH levels } \\
\text { Pooled data set from all } 4 \\
\text { centers: NS }\end{array}$ \\
\hline Guo 2018 & (254) & Serum & $\begin{array}{l}\text { Cross- } \\
\text { sectional }\end{array}$ & $\begin{array}{l}\text { sum of } 7 \text { PCB } \\
\text { congeners }\end{array}$ & $\begin{array}{l}26 \text { exposed men } \\
\text { (residents from an e- }\end{array}$ & China & $\begin{array}{l}\text { sum of PCBs: NS (with LH, FSH } \\
\text { or } T \text { ) }\end{array}$ \\
\hline
\end{tabular}


TABLE 7 | Continued

\begin{tabular}{|c|c|c|c|c|c|c|c|}
\hline EDC class & Reference & Matrix & $\begin{array}{l}\text { Study } \\
\text { design }\end{array}$ & $\begin{array}{l}\text { Chemicals/ } \\
\text { congeners reported }\end{array}$ & $\mathrm{N}$ of subjects & Country & $\begin{array}{c}\text { Association between chemical } \\
\text { levels and reproductive } \\
\text { hormone levels }\end{array}$ \\
\hline Petersen 2015 & (227) & Serum & $\begin{array}{l}\text { Cross- } \\
\text { sectional }\end{array}$ & $\begin{array}{l}\text { PCB28,105,118,156, } \\
52,101,153,138,180\end{array}$ & $\begin{array}{l}266 \text { fertile men } \\
\text { Median age, } 34.8 \text { y }\end{array}$ & $\begin{array}{l}\text { Faroe } \\
\text { Island }\end{array}$ & $\begin{array}{l}\text { Positive association between } \\
\text { PCB and T/E2 ratio, SHBG and } \\
\text { FSH levels }\end{array}$ \\
\hline Petersen 2018 & (220) & Serum & $\begin{array}{l}\text { Cross- } \\
\text { sectional }\end{array}$ & 9 PCB congeners & $\begin{array}{l}263 \text { Faroese men } \\
(24-26 y)\end{array}$ & $\begin{array}{l}\text { Faroe } \\
\text { island }\end{array}$ & $\begin{array}{l}\text { Positive association between } \\
\text { ¿PCBs and SHBG, LH, } T \text { and } \\
\text { T/E2 ratio }\end{array}$ \\
\hline Richthoff 2003 & (228) & Serum & $\begin{array}{l}\text { Cross- } \\
\text { sectional }\end{array}$ & CB-153 & $\begin{array}{l}305 \text { men from general } \\
\text { population, aged } 18-21 \text { y }\end{array}$ & Sweden & $\begin{array}{l}\text { Negative associations between } \\
\text { CB-153 levels and testosterone: } \\
\text { SHBG ratio }\end{array}$ \\
\hline Axelsson 2015 & (185) & Urine & $\begin{array}{l}\text { Cross- } \\
\text { sectional }\end{array}$ & $\begin{array}{l}10 \text { phthalate } \\
\text { metabolites }\end{array}$ & $\begin{array}{l}314 \text { men from general } \\
\text { population, aged } 17-20 \text { y }\end{array}$ & Sweden & $\begin{array}{l}\text { In adjusted models, } \\
\text { Negative associations between } \\
\% \text { MEHP and T and FT } \\
\text { No association between other } \\
\text { metabolites and TT, FT, LH, } \\
\text { FSH, E2 or SHBG }\end{array}$ \\
\hline Chang 2015 & (259) & Urine & $\begin{array}{l}\text { Case- } \\
\text { control } \\
\text { study }\end{array}$ & $\begin{array}{l}\text { Urinary concentrations } \\
\text { of } 11 \text { phthalate } \\
\text { metabolites }\end{array}$ & $\begin{array}{l}176 \\
\text { Infertile men from } \\
\text { infertility clinic } \\
\text { and fertile men } \\
\text { (mean age, } 34.2 \mathrm{y})\end{array}$ & Taiwan & $\begin{array}{l}\text { Urinary MnBP, MEHP and } \\
\text { mono-2-ethyl-5-carboxy pentyl } \\
\text { phthalate: infertile > fertile men } \\
\text { Negative association between } \\
\text { urinary MMP, MiBP, MEHP, } \\
\text { MEHP\% and serum TT } \\
\text { Negative association between } \\
\text { urinary MiBP, MBzP, MEHP, } \\
\text { MEHP\% and serum FT } \\
\text { Negative association between } \\
\text { urinary MMP, MEHP, MEHP\% } \\
\text { and TT:LH ratio } \\
\text { Negative association between } \\
\text { urinary MMP, MiBP, MnBP, } \\
\text { MBzP, MEHP and FAl }\end{array}$ \\
\hline Joensen 2012 & (188) & Urine & $\begin{array}{l}\text { Cross- } \\
\text { sectional }\end{array}$ & $\begin{array}{l}14 \text { urinary phthalate } \\
\text { metabolites }\end{array}$ & $\begin{array}{l}881 \text { men from general } \\
\text { population (median age, } \\
19.1 \mathrm{y} \text { ) }\end{array}$ & Denmark & $\begin{array}{l}\text { FAl: } 15 \% \text { lower for men in the } \\
\text { highest \%MiNP quartile vs } \\
\text { lowest quartile } \\
\text { FAl: } 9 \% \text { lower in the highest \% } \\
\text { MEHP quartile } \\
\text { T/LH, T/FSH: negative } \\
\text { association with \%MEHP, \% } \\
\text { MiNP } \\
\% M E H P \text { had negative } \\
\text { association with TT, FT, T/E2 }\end{array}$ \\
\hline Henrotin 2020 & (260) & Urine & $\begin{array}{l}\text { Short } \\
\text { longitudinal }\end{array}$ & $\begin{array}{l}\text { Urinary OXO-MINP, } \\
\text { CX-MINP, OH-MINP }\end{array}$ & $\begin{array}{l}97 \text { male workers } \\
\text { (mean age, } 44.5 \mathrm{y})\end{array}$ & France & $\begin{array}{l}\text { Urinary OXO-MINP had negative } \\
\text { association with } \Pi \pi\end{array}$ \\
\hline Chen 2017 & (261) & Urine & $\begin{array}{l}\text { Cross- } \\
\text { sectional }\end{array}$ & $\begin{array}{l}7 \text { urine phthalate } \\
\text { metabolites }\end{array}$ & $\begin{array}{l}786 \text { subjects, aged } 12- \\
30 \text { y, from general } \\
\text { population }\end{array}$ & Taiwan & $\begin{array}{l}\text { Negative association between } \\
\text { urinary MEHP and T in men } \\
\text { aged } 20-30 \text { y }\end{array}$ \\
\hline
\end{tabular}


TABLE 7 | Continued



(Continued) 
TABLE 7 | Continued

\begin{tabular}{|c|c|c|c|c|c|c|c|}
\hline EDC class & Reference & Matrix & $\begin{array}{l}\text { Study } \\
\text { design }\end{array}$ & $\begin{array}{l}\text { Chemicals/ } \\
\text { congeners reported }\end{array}$ & $\mathrm{N}$ of subjects & Country & $\begin{array}{c}\text { Association between chemical } \\
\text { levels and reproductive } \\
\text { hormone levels }\end{array}$ \\
\hline Wang 2016 & $(198)$ & Seminal fluid & $\begin{array}{l}\text { Cross- } \\
\text { sectional }\end{array}$ & 8 phthalate metabolites & $\begin{array}{l}\text { Male partners of } \\
\text { subfertile couples } \\
\text { Semen samples }(n= \\
687) \text { Blood samples ( } n \\
=342 \text { ) }\end{array}$ & China & NS \\
\hline Wang 2016 & (267) & Urine & $\begin{array}{l}\text { Cross- } \\
\text { sectional }\end{array}$ & 8 phthalate metabolites & $\begin{array}{l}483 \text { male partners of } \\
\text { couples attending } \\
\text { fertility clinic } \\
\text { Who had serum } \\
\text { reproductive hormone } \\
\text { measurement } \\
\text { Mean age, } 32.1 \mathrm{y}\end{array}$ & China & $\begin{array}{l}\text { Negative association between } \\
\text { MEHP, DEHP and E2, TT and } \\
\text { FT levels }\end{array}$ \\
\hline & & & & & & & $\begin{array}{l}\text { - Negative association between } \\
\Sigma \mathrm{LMW} \text { phthalates and } \mathrm{FT} \\
\text { Age } 40-59 \mathrm{y} \\
\text { - Positive association between } \\
\Sigma \mathrm{LMW} \text { phthalates and } \mathrm{FT} \\
\text { - Negative association between } \\
\sum \mathrm{DINCH} \text { and } T \\
\text { Age } \geq 60 \mathrm{y} \\
\text { - Negative association between } \\
\sum \mathrm{DEHP}, \Sigma \mathrm{DINCH} \text { and } T \text {, } \\
\text { between } \Sigma \mathrm{DEHP}, \Sigma \mathrm{DINP} \text { and } \\
\mathrm{E} 2 \text { and between } \Sigma \mathrm{HMW}, \\
\sum \mathrm{DEHP} \text { and } \mathrm{FT}\end{array}$ \\
\hline Lewis 2015 & (219) & Serum & $\begin{array}{l}\text { Cross- } \\
\text { sectional }\end{array}$ & $\begin{array}{l}\text { PFASs } \\
\text { Serum T }\end{array}$ & $\begin{array}{l}857 \text { males from general } \\
\text { population } \\
\text { Age } 12-80 \text { y }\end{array}$ & USA & NS with $T$ \\
\hline Petersen 2018 & (220) & Serum & $\begin{array}{l}\text { Cross- } \\
\text { sectional }\end{array}$ & Blood for PFASs & $\begin{array}{l}263 \text { Faroese men (24- } \\
26 \text { y) }\end{array}$ & $\begin{array}{l}\text { Faroe } \\
\text { island }\end{array}$ & $\begin{array}{l}\text { Positive association between } \\
\text { PFOS and SHBG and LH }\end{array}$ \\
\hline Joensen 2009 & (218) & Serum & $\begin{array}{l}\text { Cross- } \\
\text { sectional }\end{array}$ & $\begin{array}{l}\text { PFHxS, PFHpA, PFOA, } \\
\text { PFOS, PFOSA, PFNA, } \\
\text { PFDA, PFUnA, } \\
\text { PFDoA, PFTrA }\end{array}$ & $\begin{array}{l}105 \text { men } \\
(53 \text { men with the } \\
\text { highest T level and } 52 \\
\text { men with the lowest T } \\
\text { level) } \\
\text { Median age, } 19 \text { y }\end{array}$ & Denmark & $\begin{array}{l}\text { NS } \\
\text { (T, E2, SHBG, FSH, LH, inhibin } \\
\text { B, FAl, T/LH, FAI/LH, E2/T and } \\
\text { inhibin/FSH) }\end{array}$ \\
\hline Joensen 2013 & (221) & Serum & $\begin{array}{l}\text { Cross- } \\
\text { sectional }\end{array}$ & 14 PFASs & $\begin{array}{l}247 \text { men from general } \\
\text { population } \\
\text { Mean age } 19.6 \text { y }\end{array}$ & Denmark & $\begin{array}{l}\text { Negative association between } \\
\text { PFOS and TT, FT, FAl, FT/LH, } \\
\text { FAl/LH, T/LH ratios } \\
\text { Negative association between } \\
\text { PFNA and E2 }\end{array}$ \\
\hline
\end{tabular}


TABLE 7 | Continued

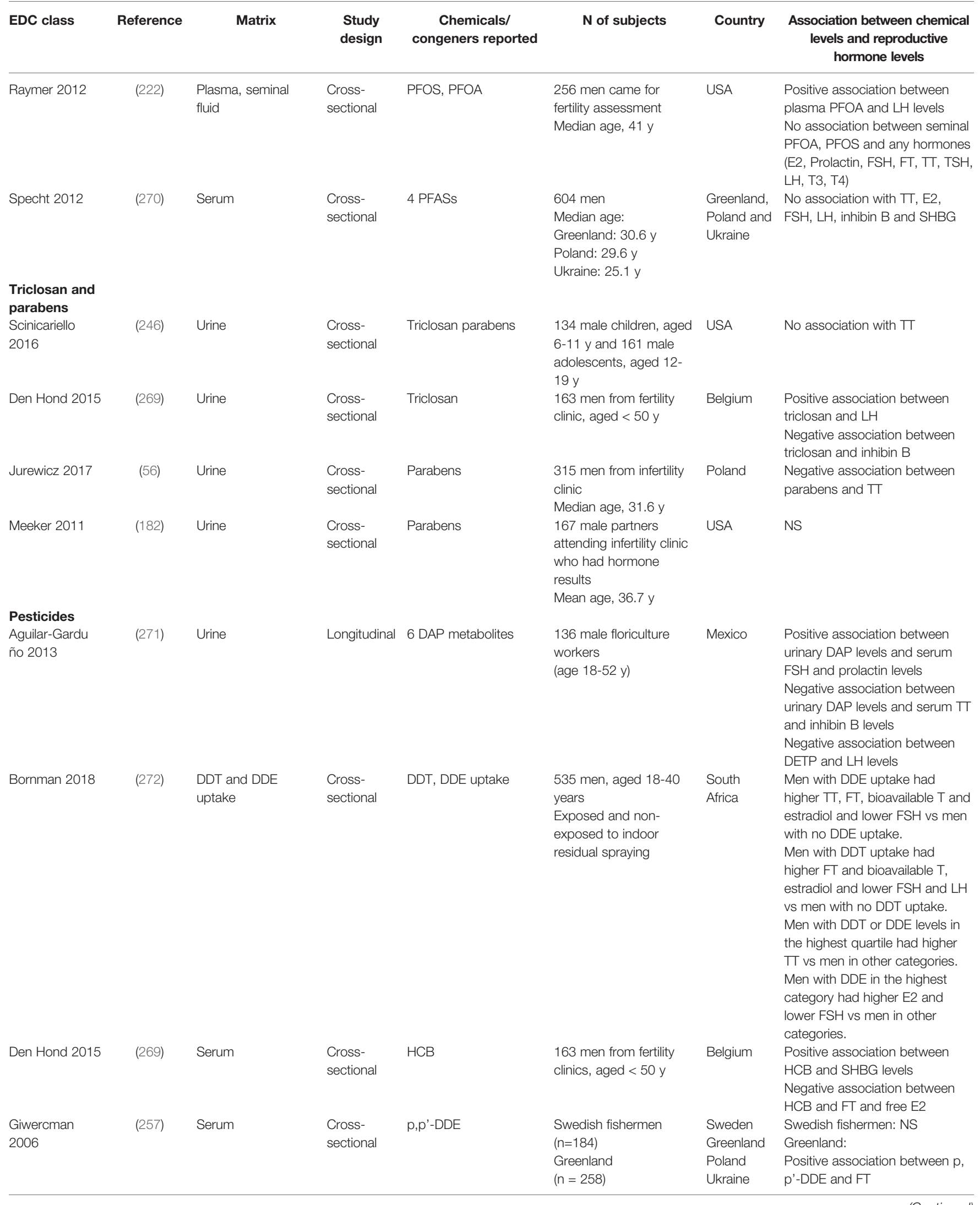


TABLE 7 | Continued

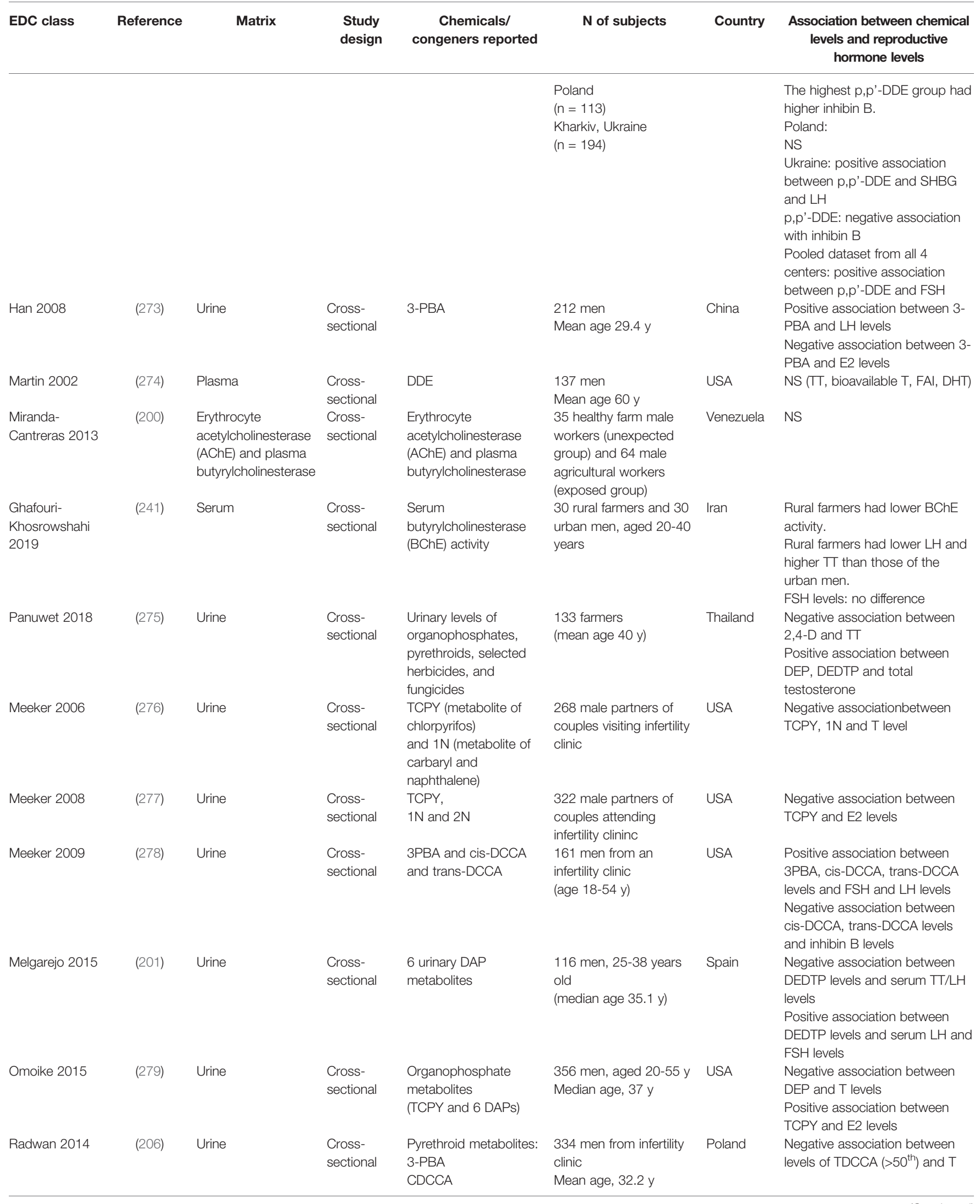


TABLE 7 | Continued

\begin{tabular}{|c|c|c|c|c|c|c|c|}
\hline EDC class & Reference & Matrix & $\begin{array}{l}\text { Study } \\
\text { design }\end{array}$ & $\begin{array}{c}\text { Chemicals/ } \\
\text { congeners reported }\end{array}$ & $\mathrm{N}$ of subjects & Country & $\begin{array}{c}\text { Association between chemical } \\
\text { levels and reproductive } \\
\text { hormone levels }\end{array}$ \\
\hline & & & & $\begin{array}{l}\text { TDCCA } \\
\text { DBCA }\end{array}$ & & & \\
\hline Specht 2015 & (216) & Serum & $\begin{array}{l}\text { Cross- } \\
\text { sectional }\end{array}$ & $\mathrm{HCB}$ & $\begin{array}{l}589 \text { fertile men } \\
\text { Median age: } \\
\text {-Greenland } 30.6 \text { y } \\
\text { - Poland } 29.6 \text { y } \\
\text { - Ukraine } 25 \text { y }\end{array}$ & $\begin{array}{l}\text { Greenland } \\
\text { Poland } \\
\text { Ukraine }\end{array}$ & $\begin{array}{l}\text { Positive association between } \\
\text { HCB and SHBG } \\
\text { Negative association between } \\
\text { HCB and FAI }\end{array}$ \\
\hline Yoshinaga 2014 & $(280)$ & Urine & $\begin{array}{l}\text { Cross- } \\
\text { sectional }\end{array}$ & 3-PBA & $\begin{array}{l}322 \text { male university } \\
\text { students, aged 18-24 y }\end{array}$ & Japan & NS \\
\hline
\end{tabular}

NS, no statistically significant association.

Only statistically significant findings are shown.

Epidemiological studies, most of which were cross-sectional, have shown inconsistent results on the association between phthalate and reproductive hormone levels. Phthalates or phthalate metabolites were measured in urine in most studies $(184,260-262,264,265,267,282)$, in serum in three studies (199, 263) and in seminal fluid in three studies $(193,198,215)$. Numerous studies showed an association between levels of phthalates or phthalate metabolites and low serum total or free testosterone levels $(189,195,258,260,261,264,265,267,268$, 282,283 ), and one study also found a concurrent low LH level (195), suggesting an impaired LH secretion as a cause of low testosterone level. Some studies assessed levels of serum inhibin $B$, which reflects Sertoli and germ cell function and/or number, and they showed that there was no association between phthalate and inhibin B levels $(188,199,263,266,284,285)$, except for a negative association between urinary MiBP levels and serum inhibin B levels which was found in a Chinese study (259).

\subsubsection{Polychlorinated Biphenyls}

Some studies have demonstrated a negative association between PCB exposure and serum total testosterone levels $(179,286)$. Some studies have shown an association with low free testosterone level $(179,228,257,287)$, which might be due to an associated increased SHBG level in some studies $(228,257)$. Most studies did not show any significant associations with FSH and $\mathrm{LH}$, except for two studies. Lin et al. found a negative association between CB52, CB209 and LH level and a positive association between CB44 and LH level (288), while CB170 level was positively associated with total testosterone levels (288). Petersen et al. reported a positive association between PCB level and serum FSH level (227). Giwercman et al. found no association between PCB level and serum FSH and inhibin B levels in Sweden, Greenland, Poland, and Ukraine, suggesting no disturbance in the hypothalamic-pituitarySertoli cell axis (257). A study from China found either no significant association between serum PCB levels and reproductive hormone levels (254). Overall, evidence suggests a link between PCB exposure and disturbed hypothalamic-pituitarygonadal axis in men, particularly low serum testosterone level.

\subsubsection{Perfluorinated Compounds}

Cross-sectional studies on the link between perfluorinated compound and reproductive hormone levels in adult men have shown inconsistent results. Four studies did not show any significant association $(218,219,269,270)$. Only one study by Joensen et al. showed negative associations with total and free testosterone levels, free androgen index, free testosterone/LH, total testosterone/LH and free androgen index/LH (289). Positive association between serum PFOS and LH was shown in one study (220) and between plasma PFOA and LH in another study (222).

\subsubsection{Pesticides}

Several studies have examined the association between different pesticide exposure and reproductive hormone levels in adult (200, 201, 206, 216, 241, 257, 269, 271-280). The studies have shown mixed results, which are summarized in Table 7.

\subsection{Testicular Cancer}

Testicular germ cell tumors (TGCTs) are relatively rare - accounting for about $1 \%$ of cancers in men. However, they are the most common cancer in young adult men $(290,291)$. Their prevalence has been increasing in many Western countries (292). The main cause of this adverse trend is still unclear, but it has been proposed that EDCs might have a role (11). Testicular cancer appears to have a fetal origin, although it usually manifests after puberty when gonadotropin stimulation has started (293). Testicular cancer, cryptorchidism and hypospadias have similar prenatal risk factors and men with a history of cryptorchidism or hypospadias have an increased risk of testicular cancer (11).

Most of the studies that investigated the relationship between EDC exposure and testicular cancer used data on self-reported exposures or the occupational history or a history of chemical use without showing the chemical levels. Studies which reported EDC concentrations are scarce. Many studies are case-control studies. In addition, cohort studies evaluating the association between prenatal exposure levels and testicular cancer occurrence are lacking. Therefore, the cause-and-effect relationship is inconclusive.

\subsubsection{Early Life EDC Exposure}

Even though TGCTs are most commonly diagnosed between the ages of 15-40 years, there is evidence supporting the hypothesis that prenatal exposure to EDCs has a role in the development of testicular cancer. 
A Swedish study of 44 TGCT case mothers and 45 control mothers found that the concentrations of the sum of PCBs, sum of PBDEs, hexachlorobenzene (HCB), cis- and transnonachlordane and sum of chlordanes were higher in case mothers than in control mothers $(294,295)$, suggesting a link between prenatal exposure to these chemicals and the development of TGCTs. The chemical levels of maternal blood samples were analyzed when the sons were diagnosed with testicular cancer. Chemical measurements were not performed in the blood taken during pregnancy; therefore, the timing of chemical exposure was unclear. However, these findings suggest a link between testicular cancer and chemical exposures, since these organochlorines have very long half-life and can stay in human body for several years.

\subsubsection{Concurrent EDC exposure}

\subsubsection{Pesticides}

A nested case-control study of 49 TGCT cases and 51 controls in Norway used pre-diagnostic serum samples, and no significant difference in the levels of oxychlordane, trans-nonachlor, and total chlordanes between the cases and controls was reported (296).

To date, five case-control studies have examined relationship between pre-diagnostic serum levels of p,p'-DDE and TGCTs. Two studies found higher levels of p, p'-DDE in TGCT group than those in the controls. A study among US servicemen (297) and a hospital-based study in Italy showed that the TGCT cases had significantly higher p,p'-DDE levels than those of the controls (298). A Swedish study and a Norwegian study found a tendency to higher serum p,p'-DDE levels among the TGCT cases as compared with controls; however, the difference was not statistically significant $(295,296)$. Another US study did not show an association between TGCT and serum DDE (299).

\subsubsection{Polychlorinated Biphenyls}

Three studies have investigated the associations between PCB exposure and the occurrence of TGCTs. A study in Norway found that the levels of some PCB congeners (PCB-99, -138, $-153,-167,-183$ and -195) were significantly higher in seminoma cases and the levels of some PCB congeners (PCB$44,-49,-52)$ were significantly lower in seminoma cases than in the controls (296). A case-control study in Sweden found no difference between the levels of PCBs between TGCT cases and controls (300). An Italian study found that men with detectable levels of total polychlorinated organic compounds (PCB congeners (PCB-31, -28, -52, -77, -153, -126, -180, -169, -170) and hexachlorobenzene) had increased risk of TGCTs as compared with men with undetectable levels (301). In contrast, a US study found that PCB-118, PCB-138, PCB-153, PCB-156, PCB-163, PCB-170, PCB-180, PCB-187 levels were associated with a decreased risk of TGCT and PCB-99, PCB101 , PCB-183 were not associated with the occurrence of TGCT (302).

In summary, studies on the role of prenatal EDC exposure on TGCTs are scarce. Studies evaluating the role of concurrent EDC exposure on TGCTs have shown mixed results. However, significant associations between EDC exposure and testicular cancer have been shown at least in some studies. More studies are needed to further assess these connections.

\section{DISCUSSION}

There has been a growing research interest in the potential health risk of EDCs during recent years. Experimental studies support the role of EDC exposure in the occurrence of male reproductive health problems. Results from epidemiological studies are mixed, however, evidence suggests a link between some EDC exposures and adverse male reproductive health. Maternal exposure to some EDCs during pregnancy has, at least in part of the studies, been associated with congenital urogenital anomalies, i.e., cryptorchidism and hypospadias, and low semen quality, altered HPG hormone levels and testicular cancer in adult men. The evidence for the link to the adverse adult male reproductive health is derived from a small number of studies. The association of concurrent exposure to some EDCs in adulthood with low semen quality, low serum testosterone levels and testicular cancer has been reported, although the results are not consistent.

Human studies on the association between exposure to environmental EDCs and male reproductive health are challenging because of a number of factors. First, we are continuously exposed to a mixture of different chemicals, which is different from many experimental studies that evaluated the effect of one chemical at a time. In addition, the level of exposure in animal models can be higher than human exposure in real life. Results from experimental studies are not always repeatable in human studies. Second, the exposure starts already at the embryonic period or even before that, since paternal exposure to environmental and lifestyle factors may change sperm epigenome and recent studies suggest that such changes may be the link between paternal exposures and offspring health $(303,304)$. Furthermore, the critical period for exposure may vary for different reproductive outcomes, since for instance hypospadias is caused by a defect in fetal development of penile urethra, but sperm production capacity is determined by the number of Sertoli cells and these cells divide fast during fetal development but also postnatally and at the beginning of puberty $(133,305)$. Therefore, the timing of exposure measurement may affect the results on the association between EDC exposure and male reproductive health. Third, participant settings - men from general population, men who had occupational exposure to EDCs, or men who lived in the areas of accidental chemical leakage - also influence the results. Studies on the effects of accidental chemical leakage have usually shown a negative impact on semen quality or male reproductive hormone levels, while studies in men from general population are more likely to show mixed results. Men recruited from an infertility clinic, men from general population and men at a different age possibly show dissimilar association to chemical exposures. In addition, differences in exposure levels between 
study population may influence the observed associations. Fourth, a cross-sectional study examines the relationship between chemical exposure and semen quality or reproductive hormones at one point of time. For a chemical with a short halflife, chemical measurement at a single point might not reflect the real level of exposure in long-term. In addition, a significant correlation observed in cross-sectional study does not indicate a cause-and-effect relationship. Lastly, studies on the association between prenatal EDC exposures and adult male reproductive outcomes, including semen quality, serum reproductive hormone levels and testicular cancer need long period of follow-up, and are therefore difficult to conduct. In addition, prenatal EDC exposure is also followed by postnatal exposure from birth to adulthood.

More studies on the effects of maternal EDC exposures on the sons' semen quality and reproductive hormone levels, and more results from birth cohort studies would be beneficial. Role of paternal EDC exposure during pre-conception,

\section{REFERENCES}

1. Levine H, Jørgensen N, Martino-Andrade A, Mendiola J, Weksler-Derri D, Mindlis I, et al. Temporal Trends in Sperm Count: A Systematic Review and Meta-Regression Analysis. Hum Reprod Update (2017) 23(6):646-59. doi: 10.1093/humupd/dmx022

2. Perheentupa A, Mäkinen J, Laatikainen T, Vierula M, Skakkebaek NE, Andersson AM, et al. A Cohort Effect on Serum Testosterone Levels in Finnish Men. Eur J Endocrinol (2013) 168(2):227-33. doi: 10.1530/EJE-120288

3. Lokeshwar SD, Patel P, Fantus RJ, Halpern J, Chang C, Kargi AY, et al. Decline in Serum Testosterone Levels Among Adolescent and Young Adult Men in the USA. Eur Urol Focus (2020) 1-4. doi: 10.1016/j.euf.2020.02.006

4. Virtanen HE, Toppari J. Epidemiology and Pathogenesis of Cryptorchidism. Hum Reprod Update (2008) 14(1):49-58. doi: 10.1093/humupd/dmm027

5. Znaor A, Lortet-Tieulent J, Jemal A, Bray F. International Variations and Trends in Testicular Cancer Incidence and Mortality. Eur Urol (2014) 65:1095-106. doi: 10.1016/j.eururo.2013.11.004

6. Bergman Å, Heindel J, Jobling S, Kidd K, Zoeller R. State of the Science of Endocrine Disrupting Chemicals 2012. United Nations Environment Programme and the World Health Organization (2013). WHO Press, World Health Organization, 20 Avenue Appia, 1211 Geneva 27, Switzerland.

7. Gore AC, Chappell VA, Fenton SE, Flaws JA, Nadal A, Prins GS, et al. EDC2: The Endocrine Society's Second Scientific Statement on EndocrineDisrupting Chemicals. Endocr Rev (2015) 36:1-150. doi: 10.1210/er.20151010

8. Rider CV, Furr JR, Wilson VS, Gray LE. Cumulative Effects of In Utero Administration of Mixtures of Reproductive Toxicants That Disrupt Common Target Tissues via Diverse Mechanisms of Toxicity. In: International Journal of Andrology. Int J Androl (2010) 33:443-62. doi: 10.1111/j.1365-2605.2009.01049.x

9. Beausoleil C, Ormsby J, Gies A, Hass U, Heindel J, Holmer M, et al. Low Dose Effects and Non-Monotonic Dose Responses for Endocrine Active Chemicals: Science to Practice Workshop: Workshop Summary. Chemosphere (2013) 93(6):847-56. doi: 10.1016/j.chemosphere.2013.06.043

10. Vandenberg LN, Colborn T, Hayes TB, Heindel JJ, Jacobs DR, Lee DH, et al. Hormones and Endocrine-Disrupting Chemicals: Low-Dose Effects and Nonmonotonic Dose Responses. Endocr Rev (2012) 33p:378-455. doi: 10.1210/er.2011-1050

11. Skakkebaek NE, Rajpert-De Meyts E, Buck Louis GM, Toppari J, Andersson A-M, Eisenberg ML, et al. Male Reproductive Disorders and Fertility Trends: particularly epigenetic studies, is a topic that needs to be studied further.

\section{AUTHOR CONTRIBUTIONS}

All authors listed have made a substantial, direct, and intellectual contribution to the work and approved it for publication.

\section{FUNDING}

This work was supported by the Academy of Finland (308065), Sigrid Juselius Foundation, Novo Nordisk Foundation, Special governmental funds for Turku University Hospital, Finnish Cultural Foundation, Jalmari and Rauha Ahokas Foundation, Kirsten and Freddy Johansen's Fund, Juho Vainio Foundation, Foundation for Pediatric Research and Danish Innovation Funds.
Influences of Environment and Genetic Susceptibility. Physiol Rev (2016) 96 (1):55-97. doi: 10.1152/physrev.00017.2015

12. Skakkebaek NE, Rajpert-De Meyts E, Main KM. Testicular Dysgenesis Syndrome: An Increasingly Common Developmental Disorder With Environmental Aspects. Hum Reprod (2001) 16(5):972-8. doi: 10.1093/ humrep/16.5.972

13. Kilcoyne KR, Mitchell RT. Effect of Environmental and Pharmaceutical Exposures on Fetal Testis Development and Function: A Systematic Review of Human Experimental Data. Hum Reprod Update (2019) 25(4):397-421. doi: 10.1093/humupd/dmz004

14. Wirth JJ, Mijal RS. Adverse Effects of Low Level Heavy Metal Exposure on Male Reproductive Function. Syst Biol Reprod Med (2010) 56:147-67. doi: $10.3109 / 19396360903582216$

15. de Angelis C, Galdiero M, Pivonello C, Salzano C, Gianfrilli D, Piscitelli P, et al. The Environment and Male Reproduction: The Effect of Cadmium Exposure on Reproductive Functions and Its Implication in Fertility. Reprod Toxicol (2017) 73:105-27. doi: 10.1016/j.reprotox.2017.07.021

16. De Coster S, Van Larebeke N. Endocrine-Disrupting Chemicals: Associated Disorders and Mechanisms of Action. J Environ Public Health (2012) 2012:1-52. doi: 10.1155/2012/713696

17. Kavlock R, Boekelheide K, Chapin R, Cunningham M, Faustman E, Foster P et al. NTP Center for the Evaluation of Risks to Human Reproduction: Phthalates Expert Panel Report on the Reproductive and Developmental Toxicity of Di-Isononyl Phthalate. Reprod Toxicol (2002) 16:679-708. doi: 10.1016/S0890-6238(02)00034-5

18. Kavlock R, Boekelheide K, Chapin R, Cunningham M, Faustman E, Foster P, et al. NTP Center for the Evaluation of Risks to Human Reproduction: Phthalates Expert Panel Report on the Reproductive and Developmental Toxicity of Di-N-Butyl Phthalate. Reprod Toxicol (2002) 16:489-527. doi: 10.1016/S0890-6238(02)00033-3

19. Ulbrich B, Stahlmann R. Developmental Toxicity of Polychlorinated Biphenyls (PCBs): A Systematic Review of Experimental Data. Arch Toxicol (2004) 78:252-68. doi: 10.1007/s00204-003-0519-y

20. Bonefeld-Jorgensen EC, Andersen HR, Rasmussen TH, Vinggaard AM. Effect of Highly Bioaccumulated Polychlorinated Biphenyl Congeners on Estrogen and Androgen Receptor Activity. Toxicology (2001) 158(3):141-53. doi: 10.1016/S0300-483X(00)00368-1

21. Sikka SC, Wang R. Endocrine Disruptors and Estrogenic Effects on Male Reproductive Axis. Asian J Androl (2008) 10:134-45. doi: 10.1111/j.17457262.2008.00370.x

22. Ralph JL, Orgebin-Crist MC, Lareyre JJ, Nelson CC. Disruption of Androgen Regulation in the Prostate by the Environmental Contaminant 
Hexachlorobenzene. Environ Health Perspect (2003) 111:461-6. doi: 10.1289/ehp.5919

23. Lemaire G, Terouanne B, Mauvais P, Michel S, Rahmani R. Effect of Organochlorine Pesticides on Human Androgen Receptor Activation In Vitro. Toxicol Appl Pharmacol (2004) 196(2):235-46. doi: 10.1016/ j.taap.2003.12.011

24. Giwercman A, Rylander L, Giwercman YL. Influence of Endocrine Disruptors on Human Male Fertility. Reprod BioMed Online (2007) 15:633-42. doi: 10.1016/S1472-6483(10)60530-5

25. Jayaraj R, Megha P, Sreedev P. Review Article. Organochlorine Pesticides, Their Toxic Effects on Living Organisms and Their Fate in the Environment. Interdiscip Toxicol (2016) 9:90-100. doi: 10.1515/intox-2016-0012

26. Hunter DJ, Hankinson SE, Laden F, Colditz GA, Manson JE, Willett WC, et al. Plasma Organochlorine Levels and the Risk of Breast Cancer. N Engl J Med (1997) 337(18):1253-8. doi: 10.1056/NEJM199710303371801

27. Cook MB, Trabert B, Mcglynn KA. Organochlorine Compounds and Testicular Dysgenesis Syndrome: Human Data. Int J Androl (2011) 34: e68-e85. doi: 10.1111/j.1365-2605.2011.01171.x

28. Wolff MS. Half-Lives of Organochlorines (OCs) in Humans. Arch Environ Contam Toxicol (1999) 36:504. doi: 10.1007/PL00006624

29. Meeker JD, Hauser R. Exposure to Polychlorinated Biphenyls (PCBs) and Male Reproduction. Syst Biol Reprod Med (2010) 56(2):122-31. doi: 10.3109/ 19396360903443658

30. Djien Liem AK, Furst P, Rappe C. Exposure of Populations to Dioxins and Related Compounds. Food Addit Contam (2000) 17(4):241-59. doi: 10.1080/ 026520300283324

31. Schmitt L, Hinxlage I, Cea PA, Gohlke H, Wesselborg S. 40 Years of Research on Polybrominated Diphenyl Ethers (PBDEs)-A Historical Overview and Newest Data of a Promising Anticancer Drug. Molecules (2021) 26(4):1-32. doi: 10.3390/molecules26040995

32. Hoang AQ, Tran TM, Tu MB, Takahashi S. Polybrominated Diphenyl Ethers in Indoor and Outdoor Dust From Southeast Asia: An Updated Review on Contamination Status, Human Exposure, and Future Perspectives. Environ Pollut (2021) 272:1-17. doi: 10.1016/j.envpol. 2020.116012

33. Sato T, Miyagawa S, Iguchi T. Polybrominated Diphenyl Ether. In: Handbook of Hormones. Elsevier (2016) 589-90. doi: 10.1016/B978-0-12801028-0.00248-8

34. Jensen AA, Leffers H. Emerging Endocrine Disrupters: Perfluoroalkylated Substances. Int J Androl (2008) 31:161-9. doi: 10.1111/j.13652605.2008.00870.x

35. Wang M, Park JS, Petreas M. Temporal Changes in the Levels of Perfluorinated Compounds in California Women's Serum Over the Past 50 Years. Environ Sci Technol (2011) 45(17):7510-6. doi: 10.1021/es2012275

36. Steenland K, Fletcher T, Savitz DA. Epidemiologic Evidence on the Health Effects of Perfluorooctanoic Acid (PFOA). Environ Health Perspect (2010) 118:1100-8. doi: 10.1289/ehp.0901827

37. Post GB, Cohn PD, Cooper KR. Perfluorooctanoic Acid (PFOA), an Emerging Drinking Water Contaminant: A Critical Review of Recent Literature. Environ Res (2012) 116:93-117. doi: 10.1016/j.envres.2012.03.007

38. Genuis SJ, Birkholz D, Ralitsch M, Thibault N. Human Detoxification of Perfluorinated Compounds. Public Health (2010) 124(7):367-75. doi: 10.1016/j.puhe.2010.03.002

39. de Araújo JFP, Podratz PL, Merlo E, Sarmento IV, da Costa CS, Niño OMS, et al. Organotin Exposure and Vertebrate Reproduction: A Review. Front Endocrinol (2018) 9:64. doi: 10.3389/fendo.2018.00064

40. Dziewirska E, Hanke W, Jurewicz J. Environmental Non-Persistent Endocrine-Disrupting Chemicals Exposure and Reproductive Hormones Levels in Adult Men. Int J Occup Med Environ Health (2018) 31:551-73. doi: 10.13075/ijomeh.1896.01183

41. Vandenberg LN, Hauser R, Marcus M, Olea N, Welshons WV. Human Exposure to Bisphenol A (BPA). Reprod Toxicol (2007) 24:139-77. doi: 10.1016/j.reprotox.2007.07.010

42. Michałowicz J. Bisphenol A - Sources, Toxicity and Biotransformation. Environ Toxicol Pharmacol (2014) 37:738-58. doi: 10.1016/ j.etap. 2014.02 .003

43. Gould JC, Leonard LS, Maness SC, Wagner BL, Conner K, Zacharewski T, et al. Bisphenol A Interacts With the Estrogen Receptor $\alpha$ in a Distinct
Manner From Estradiol. Mol Cell Endocrinol (1998) 142(1-2):203-14. doi: 10.1016/S0303-7207(98)00084-7

44. Tomza-Marciniak A, Stępkowska P, Kuba J, Pilarczyk B. Effect of Bisphenol A on Reproductive Processes: A Review of In Vitro, In Vivo and Epidemiological Studies. J Appl Toxicol (2018) 38(1):51-80. doi: 10.1002/ jat.3480

45. Hart RJ. The Impact of Prenatal Exposure to Bisphenol A on Male Reproductive Function. Front Endocrinol (2020) 11:1-6. doi: 10.3389/ fendo. 2020.00320

46. Matuszczak E, Komarowska MD, Debek W, Hermanowicz A. The Impact of Bisphenol A on Fertility, Reproductive System, and Development: A Review of the Literature. Int J Endocrinol (2019) 2019. doi: 10.1155/2019/4068717

47. Wisniewski P, Romano RM, Kizys MML, Oliveira KC, Kasamatsu T, Giannocco G, et al. Adult Exposure to Bisphenol A (BPA) in Wistar Rats Reduces Sperm Quality With Disruption of the Hypothalamic-PituitaryTesticular Axis. Toxicology (2015) 329:1-9. doi: 10.1016/j.tox.2015.01.002

48. Lukasiewicz M, Czerniecki J, Ponikwicka-Tyszko D, Sztachelska M, Hryniewicka M, Nalewajko-Sieliwoniuk E, et al. Placenta is Capable of Protecting the Male Fetus From Exposure to Environmental Bisphenol a. Expo Heal (2021) 13(1):1-14. doi: 10.1007/s12403-020-00358-5

49. Dekant W, Völkel W. Human Exposure to Bisphenol A by Biomonitoring: Methods, Results and Assessment of Environmental Exposures. Toxicol Appl Pharmacol (2008) 228:114-34. doi: 10.1016/j.taap.2007.12.008

50. Rochester JR, Bolden AL. Bisphenol S and F: A Systematic Review and Comparison of the Hormonal Activity of Bisphenol a Substitutes. Environ Health Perspect (2015) 123:643-50. doi: 10.1289/ehp.1408989

51. Radke EG, Braun JM, Meeker JD, Cooper GS, Agency USEP, States U. Phthalate Exposure and Male Reproductive Outcomes : A Systematic Review of the Human Epidemiological Evidence. Environ Int (2018) 121 (October):764-93. doi: 10.1016/j.envint.2018.07.029

52. Mitchell RT, Childs AJ, Anderson RA, Van Den Driesche S, Saunders PTK, McKinnell C, et al. Do Phthalates Affect Steroidogenesis by the Human Fetal Testis? Exposure of Human Fetal Testis Xenografts to Di-N-Butyl Phthalate. J Clin Endocrinol Metab (2012) 97(3):E341-8. doi: 10.1210/jc.2011-2411

53. Hoppin JA, Brock JW, Davis BJ, Baird DD. Reproducibility of Urinary Phthalate Metabolites in First Morning Urine Samples. Environ Health Perspect (2002) 110(5):515-8. doi: 10.1289/ehp.02110515

54. Johns LE, Cooper GS, Galizia A, Meeker JD. Exposure Assessment Issues in Epidemiology Studies of Phthalates. Environ Int (2015) 85:27-39. doi: 10.1016/j.envint.2015.08.005

55. Petric Z, Ruzić J, Zuntar I. The Controversies of Parabens - an Overview Nowadays. Acta Pharma Sciendo (2021) 71:17-32. doi: 10.2478/acph-20210001

56. Jurewicz J, Radwan M, Wielgomas B, Dziewirska E, Karwacka A, Klimowska A, et al. Human Semen Quality, Sperm DNA Damage, and the Level of Reproductive Hormones in Relation to Urinary Concentrations of Parabens. J Occup Environ Med (2017) 59(11):1034-40. doi: 10.1097/JOM. 0000000000001106

57. Witorsch RJ, Thomas JA. Personal Care Products and Endocrine Disruption: A Critical Review of the Literature. Crit Rev Toxicol (2010) 40:1-30. doi: 10.3109/10408444.2010.515563

58. Sengupta P, Banerjee R. Environmental Toxins: Alarming Impacts of Pesticides on Male Fertility. Hum Exp Toxicol (2014) 33(10):1017-39. doi: 10.1177/0960327113515504

59. Mehrpour O, Karrari P, Zamani N, Tsatsakis AM, Abdollahi M. Occupational Exposure to Pesticides and Consequences on Male Semen and Fertility: A Review. Toxicol Lett (2014) 230(2):146-56. doi: 10.1016/ j.toxlet.2014.01.029

60. Tirado OM, Selva DM, Toràn N, Suárez-Quian CA, Jansen M, McDonnell DP, et al. Increased Expression of Estrogen Receptor $\beta$ in Pachytene Spermatocytes After Short-Term Methoxyacetic Acid Administration. J Androl (2004) 25(1):84-94. doi: 10.1002/j.1939-4640.2004.tb02762.x

61. Tirado OM, Martínez ED, Rodriguéz OC, Danielsen M, Selva DM, Reventós J, et al. Methoxyacetic Acid Disregulation of Androgen Receptor and Androgen-Binding Protein Expression in Adult Rat Testis. Biol Reprod (2003) 68(4):1437-46. doi: 10.1095/biolreprod.102.004937

62. Loreto-Gómez C, Farías P, Moreno-Macías H, Guzmán C, Riojas-Rodríguez H. Prenatal Exposure to Persistent Organic Compounds and Their 
Association With Anogenital Distance in Infants. Reprod BioMed Online (2018) 37(6):732-40. doi: 10.1016/j.rbmo.2018.09.008

63. Welsh M, Saunders PTK, Fisken M, Scott HM, Hutchison GR, Smith LB, et al. Identification in Rats of a Programming Window for Reproductive Tract Masculinization, Disruption of Which Leads to Hypospadias and Cryptorchidism. J Clin Invest (2008) 118(4):1479-90. doi: 10.1172/JCI34241

64. Dean A, Sharpe RM. Anogenital Distance or Digit Length Ratio as Measures of Fetal Androgen Exposure: Relationship to Male Reproductive Development and Its Disorders. J Clin Endocrinol Metab (2013) 98:22308. doi: 10.1210/jc.2012-4057

65. Schwartz CL, Christiansen S, Vinggaard AM, Axelstad M, Hass U, Svingen T. Anogenital Distance as a Toxicological or Clinical Marker for Fetal Androgen Action and Risk for Reproductive Disorders. Arch Toxicol (2019) 93:253-72. doi: 10.1007/s00204-018-2350-5

66. Vafeiadi M, Agramunt S, Papadopoulou E, Besselink H, Mathianaki K, Karakosta P, et al. In Utero Exposure to Dioxins and Dioxin-Like Compounds and Anogenital Distance in Newborns and Infants. Environ Health Perspect (2013) 121(1):126-30. doi: 10.1289/ehp.1205221

67. García-Villarino M, Riaño-Galán I, Rodríguez-Dehli AC, Freire C, Vizcaíno E, Grimalt JO, et al. Association Between Pre/Perinatal Exposure to POPs and Children's Anogenital Distance at Age 4 Years: A Study From the INMA-Asturias Cohort. Int J Hyg Environ Health (2020) 229:1-11. doi: 10.1016/j.ijheh.2020.113563

68. Luan M, Liang H, Yang F, Yuan W, Chen A, Liu X, et al. Prenatal Polybrominated Diphenyl Ethers Exposure and Anogenital Distance in Boys From a Shanghai Birth Cohort. Int J Hyg Environ Health (2019) 222 (3):513-23. doi: 10.1016/j.ijheh.2019.01.008

69. García-Villarino M, Riaño-Galán I, Rodriguez-Dehli AC, Vizcaíno E, Grimalt JO, Tardón A, et al. Prenatal Exposure to Persistent Organic Pollutants and Anogenital Distance in Children at 18 Months. Horm Res Paediatr (2018) 90(2):116-22. doi: 10.1159/000492236

70. Fisher BG, Thankamony A, Mendiola J, Petry CJ, Frederiksen H, Andersson AM, et al. Maternal Serum Concentrations of Bisphenol A and Propyl Paraben in Early Pregnancy Are Associated With Male Infant Genital Development. Hum Reprod (2020) 35(4):913-28. doi: 10.1093/humrep/ deaa 045

71. Arbuckle TE, MacPherson S, Foster WG, Sathyanarayana S, Fisher M, Monnier P, et al. Prenatal Perfluoroalkyl Substances and Newborn Anogenital Distance in a Canadian Cohort. Reprod Toxicol (2020) 94:319. doi: 10.1016/j.reprotox.2020.03.011

72. Lind DV, Priskorn L, Lassen TH, Nielsen F, Kyhl HB, Kristensen DM, et al. Prenatal Exposure to Perfluoroalkyl Substances and Anogenital Distance at 3 Months of Age in a Danish Mother-Child Cohort. Reprod Toxicol (2017) 68:200-6. doi: 10.1016/j.reprotox.2016.08.019

73. Tian Y, Liang H, Miao M, Yang F, Ji H, Cao W, et al. Maternal Plasma Concentrations of Perfluoroalkyl and Polyfluoroalkyl Substances During Pregnancy and Anogenital Distance in Male Infants. Hum Reprod (2019) 34 (7):1356-68. doi: 10.1093/humrep/dez058

74. Bornman MS, Chevrier J, Rauch S, Crause M, Obida M, Sathyanarayana S, et al. Dichlorodiphenyltrichloroethane Exposure and Anogenital Distance in the Venda Health Examination of Mothers, Babies and Their Environment (VHEMBE) Birth Cohort Study, South Africa. Andrology (2016) 4(4):60815. doi: 10.1111/andr.12235

75. Longnecker MP, Gladen BC, Cupul-Uicab LA, Romano-Riquer SP, Weber JP, Chapin RE, et al. In Utero Exposure to the Antiandrogen 1,1-Dichloro2,2-Bis(P-Chlorophenyl) Ethylene (DDE) in Relation to Anogenital Distance in Male Newborns From Chiapas, México. Am J Epidemiol (2007) 165(9):1015-22. doi: 10.1093/aje/kwk109

76. Torres-Sanchez L, Zepeda M, Cebrián ME, Belkind-Gerson J, Garcia-Hernandez RM, Belkind-Valdovinos U, et al. Dichlorodiphenyldichloroethylene Exposure During the First Trimester of Pregnancy Alters the Anal Position in Male Infants. Ann New York Acad Sci (2008) 1140:155-62. doi: 10.1196/annals.1454.004

77. Dalsager L, Christensen LE, Kongsholm MG, Kyhl HB, Nielsen F, Schoeters G, et al. Associations of Maternal Exposure to Organophosphate and Pyrethroid Insecticides and the Herbicide 2,4-D With Birth Outcomes and Anogenital Distance at 3 Months in the Odense Child Cohort. Reprod Toxicol (2018) 76:53-62. doi: 10.1016/j.reprotox.2017.12.008
78. Mammadov E, Uncu M, Dalkan C. High Prenatal Exposure to Bisphenol a Reduces Anogenital Distance in Healthy Male Newborns. J Clin Res Pediatr Endocrinol (2018) 10(1):25-9. doi: 10.4274/jcrpe.4817

79. Sunman B, Yurdakök K, Kocer-Gumusel B, Özyüncü Ö, Akbıyık F, Balcı A, et al. Prenatal Bisphenol a and Phthalate Exposure Are Risk Factors for Male Reproductive System Development and Cord Blood Sex Hormone Levels. Reprod Toxicol (2019) 87:146-55. doi: 10.1016/j.reprotox.2019.05.065

80. Arbuckle TE, Agarwal A, MacPherson SH, Fraser WD, Sathyanarayana S, Ramsay T, et al. Prenatal Exposure to Phthalates and Phenols and Infant Endocrine-Sensitive Outcomes: The MIREC Study. Environ Int (2018) 120:572-83. doi: 10.1016/j.envint.2018.08.034

81. Huang YF, Wang PW, Huang LW, Lin MH, Yang W, Chen HC, et al. Interactive Effects of Nonylphenol and Bisphenol A Exposure With Oxidative Stress on Fetal Reproductive Indices. Environ Res (2018) 167:567-74. doi: 10.1016/j.envres.2018.08.007

82. Lassen TH, Frederiksen H, Kyhl HB, Swan SH, Main KM, Andersson AM, et al. Prenatal Triclosan Exposure and Anthropometric Measures Including Anogenital Distance in Danish Infants. Environ Health Perspect (2016) 124 (8):1261-8. doi: 10.1289/ehp.1409637

83. Liu C, Xu X, Zhang Y, Li W, Huo X. Associations Between Maternal Phenolic Exposure and Cord Sex Hormones in Male Newborns. Hum Reprod (2016) 31(3):648-56. doi: 10.1093/humrep/dev327

84. Sun X, Li D, Liang H, Miao M, Song X, Wang Z, et al. Maternal Exposure to Bisphenol A and Anogenital Distance Throughout Infancy: A Longitudinal Study From Shanghai, China. Environ Int (2018) 121(Pt 1):269-75. doi: 10.1016/j.envint.2018.08.055

85. Huang PC, Kuo PL, Chou YY, Lin SJ, Lee CC. Association Between Prenatal Exposure to Phthalates and the Health of Newborns. Environ Int (2009) 35 (1):14-20. doi: 10.1016/j.envint.2008.05.012

86. Adibi JJ, Lee MK, Naimi AI, Barrett E, Nguyen RH, Sathyanarayana S, et al. Human Chorionic Gonadotropin Partially Mediates Phthalate Association With Male and Female Anogenital Distance. J Clin Endocrinol Metab (2015) 100(9):E1216-24. doi: 10.1210/jc.2015-2370

87. Barrett ES, Parlett LE, Sathyanarayana S, Redmon JB, Nguyen RHN, Swan SH. Prenatal Stress as a Modifier of Associations Between Phthalate Exposure and Reproductive Development: Results From a Multicentre Pregnancy Cohort Study. Paediatr Perinat Epidemiol (2016) 30(2):105-14. doi: 10.1111/ppe.12264

88. Bornehag CG, Carlstedt F, Jönsson BA, Lindh CH, Jensen TK, Bodin A, et al. Prenatal Phthalate Exposures and Anogenital Distance in Swedish Boys. Environ Health Perspect (2015) 123(1):101-7. doi: 10.1289/ehp.1408163

89. Bustamante-Montes LP, Hernández-Valero MA, Flores-Pimentel D, GarcíaFábila M, Amaya-Chávez A, Barr DB, et al. Prenatal Exposure to Phthalates Is Associated With Decreased Anogenital Distance and Penile Size in Male Newborns. J Dev Orig Health Dis (2013) 4(4):300-6. doi: 10.1017/ S2040174413000172

90. Jensen TK, Frederiksen H, Kyhl HB, Lassen TH, Swan SH, Bornehag CG, et al. Prenatal Exposure to Phthalates and Anogenital Distance in Male Infants From a Low-Exposed Danish Cohort (2010-2012). Environ Health Perspect (2016) 124(7):1107-13. doi: 10.1289/ehp.1509870

91. Martino-Andrade AJ, Liu F, Sathyanarayana S, Barrett ES, Redmon JB, Nguyen RHN, et al. Timing of Prenatal Phthalate Exposure in Relation to Genital Endpoints in Male Newborns. Andrology (2016) 4(4):585-93. doi: 10.1111/andr.12180

92. Suzuki Y, Yoshinaga J, Mizumoto Y, Serizawa S, Shiraishi H. Foetal Exposure to Phthalate Esters and Anogenital Distance in Male Newborns. Int J Androl (2012) 35(3):236-44. doi: 10.1111/j.1365-2605.2011.01190.x

93. Swan SH, Main KM, Liu F, Stewart SL, Kruse RL, Calafat AM, et al. Decrease in Anogenital Distance Among Male Infants With Prenatal Phthalate Exposure. Environ Health Perspect (2005) 113(8):1056-61. doi: 10.1289/ ehp. 8100

94. Swan SH. Environmental Phthalate Exposure in Relation to Reproductive Outcomes and Other Health Endpoints in Humans. Environ Res (2008) 108 (2):177-84. doi: 10.1016/j.envres.2008.08.007

95. Swan SH, Sathyanarayana S, Barrett ES, Janssen S, Liu F, Nguyen RHN, et al. First Trimester Phthalate Exposure and Anogenital Distance in Newborns. Hum Reprod (2015) 30(4):963-72. doi: 10.1093/humrep/deu363 
96. Wenzel AG, Bloom MS, Butts CD, Wineland RJ, Brock JW, Cruze L, et al. Influence of Race on Prenatal Phthalate Exposure and Anogenital Measurements Among Boys and Girls. Environ Int (2018) 110:61-70. doi: 10.1016/j.envint.2017.10.007

97. Zarean M, Keikha M, Feizi A, Kazemitabaee M, Kelishadi R. The Role of Exposure to Phthalates in Variations of Anogenital Distance: A Systematic Review and Meta-Analysis. Environ Pollut (2019) 247:172-9. doi: 10.1016/ j.envpol.2019.01.026

98. Sharpe RM. Androgens and the Masculinization Programming Window: Human-Rodent Differences. Biochem Soc Trans (2020) 48:1725-35. doi: 10.1042/BST20200200

99. Mäkelä JA, Koskenniemi JJ, Virtanen HE, Toppari J. Testis Development. Endocr Rev (2019) 40:857-905. doi: 10.1210/er.2018-00140

100. Hutson JM, Li R, Southwell BR, Newgreen D, Cousinery M. Regulation of Testicular Descent. Pediatr Surg Int (2015) 31:317-25. doi: 10.1007/s00383015-3673-4

101. Nef S, Shipman T, Parada LF. A Molecular Basis for Estrogen-Induced Cryptorchidism. Dev Biol (2000) 224(2):354-61. doi: 10.1006/ dbio.2000.9785

102. Koskenniemi JJ, Virtanen HE, Kiviranta H, Damgaard IN, Matomäki J, Thorup JM, et al. Association Between Levels of Persistent Organic Pollutants in Adipose Tissue and Cryptorchidism in Early Childhood: A Case-Control Study. Environ Health (2015) 14(1):1-10. doi: 10.1186/s12940015-0065-0

103. Virtanen HE, Koskenniemi JJ, Sundqvist E, Main KM, Kiviranta H, Tuomisto JT, et al. Associations Between Congenital Cryptorchidism in Newborn Boys and Levels of Dioxins and PCBs in Placenta. Int J Androl (2012) 35(3):283-93. doi: 10.1111/j.1365-2605.2011.01233.x

104. Goodyer CG, Poon S, Aleksa K, Hou L, Atehortua V, Carnevale A, et al. A Case-Control Study of Maternal Polybrominated Diphenyl Ether (PBDE) Exposure and Cryptorchidism in Canadian Populations. Environ Health Perspect (2017) 125(5):057004-1-057004-9. doi: 10.1289/EHP522

105. Small CM, DeCaro JJ, Terrell ML, Dominguez C, Cameron LL, Wirth J, et al. Maternal Exposure to a Brominated Flame Retardant and Genitourinary Conditions in Male Offspring. Environ Health Perspect (2009) 117(7):11759. doi: $10.1289 /$ ehp. 0800058

106. Main KM, Kiviranta H, Virtanen HE, Sundqvist E, Tuomisto JT, Tuomisto J, et al. Flame Retardants in Placenta and Breast Milk and Cryptorchildism in Newborn Boys. Environ Health Perspect (2007) 115(10):1519-26. doi: 10.1289/ehp. 9924

107. Rantakokko P, Main KM, Wohlfart-Veje C, Kiviranta H, Airaksinen R, Vartiainen T, et al. Association of Placenta Organotin Concentrations With Congenital Cryptorchidism and Reproductive Hormone Levels in 280 Newborn Boys From Denmark and Finland. Hum Reprod (2013) 28 (6):1647-60. doi: 10.1093/humrep/det040

108. Hosie S, Loff S, Witt K, Niessen K, Waag KL. Is There a Correlation Between Organochlorine Compounds and Undescended Testes? Eur J Pediatr Surg (2000) 10:304-9. doi: 10.1055/s-2008-1072381

109. Brucker-Davis F, Wagner-Mahler K, Delattre I, Ducot B, Ferrari P, Bongain A, et al. Cryptorchidism at Birth in Nice Area (France) Is Associated With Higher Prenatal Exposure to PCBs and DDE, as Assessed by Colostrum Concentrations. Hum Reprod (2008) 23(8):1708-18. doi: 10.1093/humrep/ den186

110. Chevalier N, Brucker-Davis F, Lahlou N, Coquillard P, Pugeat M, Pacini P, et al. A Negative Correlation Between Insulin-Like Peptide 3 and Bisphenol A in Human Cord Blood Suggests an Effect of Endocrine Disruptors on Testicular Descent During Fetal Development. Hum Reprod (2015) 30 (2):447-53. doi: 10.1093/humrep/deu340

111. Axelsson J, Scott K, Dillner J, Lind $\mathrm{CH}$, Zhang $\mathrm{H}$, Rylander L, et al. Exposure to Polychlorinated Compounds and Cryptorchidism; A Nested Case-Control Study. PloS One (2020) 15 (7 July):1-9. doi: 10.1371/ journal.pone.0236394

112. McGlynn KA, Guo X, Graubard BI, Brock JW, Klebanoff MA, Longnecker MP. Maternal Pregnancy Levels of Polychlorinated Biphenyls and Risk of Hypospadias and Cryptorchidism in Male Offspring. Environ Health Perspect (2009) 117(9):1472-6. doi: 10.1289/ehp.0800389

113. Mol NM, Sørensen N, Weihe P, Andersson AM, Jørgensen N, Skakkebæk NE, et al. Spermaturia and Serum Hormone Concentrations at the Age of
Puberty in Boys Prenatally Exposed to Polychlorinated Biphenyls. Eur J Endocrinol (2002) 146(3):357-63. doi: 10.1530/eje.0.1460357

114. Toft G, Jönsson BAG, Bonde JP, Nørgaard-Pedersen B, Hougaard DM, Cohen A, et al. Perfluorooctane Sulfonate Concentrations in Amniotic Fluid, Biomarkers of Fetal Leydig Cell Function, and Cryptorchidism and Hypospadias in Danish Boys (1980-1996). Environ Health Perspect (2016) 124(1):151-6. doi: 10.1289/ehp.1409288

115. Anand-Ivell R, Cohen A, Nørgaard-Pedersen B, Jönsson BAG, Bonde JP, Hougaard DM, et al. Amniotic Fluid INSL3 Measured During the Critical Time Window in Human Pregnancy Relates to Cryptorchidism, Hypospadias, and Phthalate Load: A Large Case-Control Study. Front Physiol (2018) 9(APR):1-12. doi: 10.3389/fphys.2018.00406

116. Vesterholm Jensen D, Christensen J, Virtanen HE, Skakkebæk NE, Main KM, Toppari J, et al. No Association Between Exposure to Perfluorinated Compounds and Congenital Cryptorchidism: A Nested Case-Control Study Among 215 Boys From Denmark and Finland. Reprod (2014) 147:411-7. doi: 10.1530/REP-13-0444

117. Rouget F, Kadhel P, Monfort C, Viel JF, Thome JP, Cordier S, et al. Chlordecone Exposure and Risk of Congenital Anomalies: The Timoun Mother-Child Cohort Study in Guadeloupe (French West Indies). Environ Sci Pollut Res (2020) 27(33):40992-8. doi: 10.1007/s11356-019-06031-y

118. Damgaard IN, Skakkebæk NE, Toppari J, Virtanen HE, Shen H, Schramm KW, et al. Persistent Pesticides in Human Breast Milk and Cryptorchidism. Environ Health Perspect (2006) 114(7):1133-8. doi: 10.1289/ehp.8741

119. Bhatia R, Shiau R, Petreas M, Weintraub JM, Farhang L, Eskenazi B. Organochlorine Pesticides and Male Genital Anomalies in the Child Health and Development Studies. Environ Health Perspect (2005) 113 (2):220-4. doi: 10.1289/ehp.7382

120. Longnecker MP, Klebanoff MA, Brock JW, Zhou H, Gray KA, Needham LL, et al. Maternal Serum Level of 1,1-Dichloro-2,2-Bis(P-Chlorophenyl) Ethylene and Risk of Cryptorchidism, Hypospadias, and Polythelia Among Male Offspring. Am J Epidemiol (2002) 155(4):313-22. doi: 10.1093/aje/ 155.4.313

121. Pierik FH, Klebanoff MA, Brock JW, Longnecker MP. Maternal Pregnancy Serum Level of Heptachlor Epoxide, Hexachlorobenzene, and $\beta$ Hexachlorocyclohexane and Risk of Cryptorchidism in Offspring. Environ Res (2007) 105(3):364-9. doi: 10.1016/j.envres.2007.04.005

122. Trabert B, Longnecker MP, Brock JW, Klebanoff MA, McGlynn KA. Maternal Pregnancy Levels of Trans-Nonachlor and Oxychlordane and Prevalence of Cryptorchidism and Hypospadias in Boys. Environ Health Perspect (2012) 120(3):478-82. doi: 10.1289/ehp.1103936

123. Waliszewski SM, Infanzon RM, Gomez Arroyo S, Villalobos Pietrini R, Carvajal O, Trujillo P, et al. Persistent Organochlorine Pesticides Levels in Blood Serum Lipids in Women Bearing Babies With Undescended Testis. Bull Environ Contam Toxicol (2005) 75(5):952-9. doi: 10.1007/s00128-0050842-5

124. Fratrić I, Varga J, Vukmirović S, Sudji J, Živković D. Cryptorchidism and Pesticides: Is There a Connection? J Pediatr Surg (2017) 52(7):1166-8. doi: 10.1016/j.jpedsurg.2016.11.048

125. Komarowska MD, Hermanowicz A, Czyzewska U, Milewski R, Matuszczak E, Miltyk W, et al. Serum Bisphenol A Level in Boys With Cryptorchidism: A Step to Male Infertility? Int J Endocrinol (2015) 2015:1-8. doi: 10.1155/2015/ 973154

126. Fénichel P, Déchaux $\mathrm{H}$, Harthe $\mathrm{C}$, Gal J, Ferrari P, Pacini $\mathrm{P}$, et al. Unconjugated Bisphenol A Cord Blood Levels in Boys With Descended or Undescended Testes. Hum Reprod (2012) 27(4):983-90. doi: 10.1093/ humrep/der451

127. Chevrier C, Petit C, Philippat C, Mortamais M, Slama R, Rouget F, et al. Maternal Urinary Phthalates and Phenols and Male Genital Anomalies. Epidemiology (2012) 23:353-6. doi: 10.1097/EDE.0b013e318246073e

128. Jensen MS, Anand-Ivell R, Nørgaard-Pedersen B, Jönsson BAG, Bonde JP, Hougaard DM, et al. Amniotic Fluid Phthalate Levels and Male Fetal Gonad Function. Epidemiology (2015) 26(1):91-9. doi: 10.1097/EDE.0000000000000198

129. Main KM, Mortensen GK, Kaleva MM, Boisen KA, Damgaard IN, Chellakooty M, et al. Human Breast Milk Contamination With Phthalates and Alterations of Endogenous Reproductive Hormones in Infants Three Months of Age. Environ Health Perspect (2006) 114(2):270-6. doi: 10.1289/ ehp. 8075 
130. Warembourg C, Botton J, Lelong N, Rouget F, Khoshnood B, Le Gléau F, et al. Prenatal Exposure to Glycol Ethers and Cryptorchidism and Hypospadias: A Nested Case-Control Study. Occup Environ Med (2018) 75 (1):59-65. doi: 10.1136/oemed-2017-104391

131. Krysiak-Baltyn K, Toppari J, Skakkebaek NE, Jensen TS, Virtanen HE, Schramm KW, et al. Association Between Chemical Pattern in Breast Milk and Congenital Cryptorchidism: Modelling of Complex Human Exposures. Int J Androl (2012) 35(3):294-302. doi: 10.1111/j.1365-2605.2012.01268.x

132. Bonde JP, Flachs EM, Rimborg S, Glazer CH, Giwercman A, Ramlau-Hansen $\mathrm{CH}$, et al. The Epidemiologic Evidence Linking Prenatal and Postnatal Exposure to Endocrine Disrupting Chemicals With Male Reproductive Disorders: A Systematic Review and Meta-Analysis. Hum Reprod Update (2016) 23(1):104-25. doi: 10.1093/humupd/dmw036

133. van der Zanden LFM, van Rooij IALM, Feitz WFJ, Franke B, Knoers NVAM, Roeleveld N. Aetiology of Hypospadias: A Systematic Review of Genes and Environment. Hum Reprod Update (2012) 18:260-83. doi: 10.1093/humupd/ dms002

134. Baskin L, Shen J, Sinclair A, Cao M, Liu X, Liu G, et al. Development of the Human Penis and Clitoris. Differentiation (2018) 103:74-85. doi: 10.1016/ j.diff.2018.08.001

135. Blaschko SD, Cunha GR, Baskin LS. Molecular Mechanisms of External Genitalia Development. Differentiation (2012) 84:261-8. doi: 10.1016/ j.diff.2012.06.003

136. Thorup J, Nordenskjöld A, Hutson JM. Genetic and Environmental Origins of Hypospadias. Curr Opin Endocrinol Diabetes Obes (2014) 21:227-32. doi: 10.1097/MED.0000000000000063

137. Poon S, Koren G, Carnevale A, Aleksa K, Ling J, Ozsarfati J, et al. Association of In Utero Exposure to Polybrominated Diphenyl Ethers With the Risk of Hypospadias. JAMA Pediatr (2018) 172(9):851-6. doi: 10.1001/ jamapediatrics.2018.1492

138. Koren G, Carnevale A, Ling J, Ozsarfati J, Kapur B, Bagli D. Fetal Exposure to Polybrominated Diphenyl Ethers and the Risk of Hypospadias: Focus on the Congeners Involved. J Pediatr Urol (2019) 15(4):405.e1-6. doi: 10.1016/ j.jpurol.2019.05.023

139. Carmichael SL, Herring AH, Sjödin A, Jones R, Needham L, Ma C, et al. Hypospadias and Halogenated Organic Pollutant Levels in Maternal MidPregnancy Serum Samples. Chemosphere (2010) 80(6):641-6. doi: 10.1016/ j.chemosphere.2010.04.055

140. Giordano F, Abballe A, De Felip E, Di Domenico A, Ferro F, Grammatico P, et al. Maternal Exposures to Endocrine Disrupting Chemicals and Hypospadias in Offspring. Birth Defects Res Part A - Clin Mol Teratol (2010) 88(4):241-50. doi: 10.1002/bdra.20657

141. Rignell-Hydbom A, Lindh CH, Dillner J, Jönsson BAG, Rylander L. A Nested Case-Control Study of Intrauterine Exposure to Persistent Organochlorine Pollutants and the Risk of Hypospadias. PloS One (2012) 7(9). doi: 10.1371/ journal.pone.0044767

142. Shekharyadav C, Bajpai M, Kumar V, Ahmed RS, Gupta P, Banerjee BD. Polymorphism in CYP1A1, GSTMI,GSTT1 Genes and Organochlorine Pesticides in the Etiology of Hypospadias. Hum Exp Toxicol (2011) 30 (10):1464-74. doi: 10.1177/0960327110392402

143. Haraux E, Tourneux P, Kouakam C, Stephan-Blanchard E, Boudailliez B, Leke A, et al. Isolated Hypospadias: The Impact of Prenatal Exposure to Pesticides, as Determined by Meconium Analysis. Environ Int (2018) 119:20-5. doi: 10.1016/j.envint.2018.06.002

144. Arrebola JP, Molina-Molina JM, Fernández MF, Sáenz JM, Amaya E, Indiveri P, et al. A Novel Biomarker for Anti-Androgenic Activity in Placenta Reveals Risks of Urogenital Malformations. Reproduction (2015) 149(6):605-13. doi: 10.1530/REP-14-0525

145. Fernandez MF, Olmos B, Granada A, López-Espinosa MJ, Molina-Molina JM, Fernandez JM, et al. Human Exposure to Endocrine-Disrupting Chemicals and Prenatal Risk Factors for Cryptorchidism and Hypospadias: A Nested Case-Control Study. Environ Health Perspect (2007) 115 (SUPPL1):8-14. doi: 10.1289/ehp.9351

146. Fernández MF, Arrebola JP, Jiménez-Díaz I, Sáenz JM, Molina-Molina JM, Ballesteros O, et al. Bisphenol A and Other Phenols in Human Placenta From Children With Cryptorchidism or Hypospadias. Reprod Toxicol (2016) 59:89-95. doi: 10.1016/j.reprotox.2015.11.002
147. Sathyanarayana S, Grady R, Barrett ES, Redmon B, Nguyen RHN, Barthold JS, et al. First Trimester Phthalate Exposure and Male Newborn Genital Anomalies. Environ Res (2016) 151:777-82. doi: 10.1016/j.envres.2016.07.043

148. Carlsen E, Giwercman A, Keiding N, Skakkebaek NE. Evidence for Decreasing Quality of Semen During Past 50 Years. Bmj (1992) 305:60913. doi: 10.1136/bmj.305.6854.609

149. Hart RJ, Doherty DA, Keelan JA, Minaee NS, Thorstensen EB, Dickinson JE, et al. The Impact of Antenatal Bisphenol A Exposure on Male Reproductive Function at 20-22 Years of Age. Reprod BioMed Online (2018) 36(3):340-7. doi: 10.1016/j.rbmo.2017.11.009

150. Mocarelli P, Gerthoux PM, Needham LL, Patterson DG, Limonta G, Falbo R, et al. Perinatal Exposure to Low Doses of Dioxin can Permanently Impair Human Semen Quality. Environ Health Perspect (2011) 119(5):713-8. doi: 10.1289/ehp.1002134

151. Guo YL, Hsu PC, Hsu CC, Lambert GH. Semen Quality After Prenatal Exposure to Polychlorinated Biphenyls and Dibenzofurans. Lancet (2000) 356(9237):1240-1. doi: 10.1016/S0140-6736(00)02792-6

152. Vested A, Ramlau-Hansen CH, Olsen SF, Bonde JP, Støvring H, Kristensen SL, et al. In Utero Exposure to Persistent Organochlorine Pollutants and Reproductive Health in the Human Male. Reproduction (2014) 148(6):63546. doi: 10.1530/REP-13-0488

153. Hart RJ, Frederiksen H, Doherty DA, Keelan JA, Skakkebaek NE, Minaee NS, et al. The Possible Impact of Antenatal Exposure to Ubiquitous Phthalates Upon Male Reproductive Function at 20 Years of Age. Front Endocrinol (Lausanne) (2018) 9(JUN):1-11. doi: 10.3389/fendo.2018.00288

154. Axelsson J, Rylander L, Rignell-Hydbom A, Lindh CH, Jönsson BAG, Giwercman A. Prenatal Phthalate Exposure and Reproductive Function in Young Men. Environ Res (2015) 138:264-70. doi: 10.1016/j.envres.2015.02.024

155. Habert R, Livera G, Rouiller-Fabre V. Man is Not a Big Rat: Concerns With Traditional Human Risk Assessment of Phthalates Based on Their AntiAndrogenic Effects Observed in the Rat Foetus. Basic Clin Androl (2014) 24 (1):1-13. doi: 10.1186/2051-4190-24-14

156. Mylchreest E, Sar M, Wallace DG, Foster PMD. Fetal Testosterone Insufficiency and Abnormal Proliferation of Leydig Cells and Gonocytes in Rats Exposed to Di(N-Butyl) Phthalate. Reprod Toxicol (2002) 16(1):1928. doi: 10.1016/S0890-6238(01)00201-5

157. Parks LG, Ostby JS, Lambright CR, Abbott BD, Klinefelter GR, Barlow NJ, et al. The Plasticizer Diethylhexyl Phthalate Induces Malformations by Decreasing Fetal Testosterone Synthesis During Sexual Differentiation in the Male Rat. Toxicol Sci (2000) 58(2):339-49. doi: 10.1093/toxsci/58.2.339

158. van den Driesche S, McKinnell C, Calarrão A, Kennedy L, Hutchison GR, Hrabalkova L, et al. Comparative Effects of Di(N-Butyl) Phthalate Exposure on Fetal Germ Cell Development in the Rat and in Human Fetal Testis Xenografts. Environ Health Perspect (2015) 123(3):223-30. doi: 10.1289/ ehp. 1408248

159. Kilcoyne KR, Smith LB, Atanassova N, Macpherson S, McKinnell C, Van Den Driesche S, et al. Fetal Programming of Adult Leydig Cell Function by Androgenic Effects on Stem/Progenitor Cells. Proc Natl Acad Sci U S A (2014) 111(18):E1924-32. doi: 10.1073/pnas.1320735111

160. Engel A, Buhrke T, Imber F, Jessel S, Seidel A, Völkel W, et al. Agonistic and Antagonistic Effects of Phthalates and Their Urinary Metabolites on the Steroid Hormone Receptors Ero, Er $\beta$, and AR. Toxicol Lett (2017) 277:5463. doi: 10.1016/j.toxlet.2017.05.028

161. Charlier CJ, Foidart JM. Comparative Study of Dichlorodiphenyldichloroethylene in Blood and Semen of Two Young Male Populations: Lack of Relationship to Infertility, But Evidence of High Exposure of the Mothers. Reprod Toxicol (2005) 20(2):215-20. doi: 10.1016/j.reprotox.2005.03.007

162. Vested A, Ramlau-Hansen CH, Olsen SF, Bonde JP, Kristensen SL, Halldorsson TI, et al. Associations of in Utero Exposure to Perfluorinated Alkyl Acids With Human Semen Quality and Reproductive Hormones in Adult Men. Environ Health Perspect (2013) 121(4):453-8. doi: 10.1289/ ehp. 1205118

163. Juul A, Almstrup K, Andersson AM, Jensen TK, Jørgensen N, Main KM, et al. Possible Fetal Determinants of Male Infertility. Nat Rev Endocrinol (2014) 10(9):553-62. doi: 10.1038/nrendo.2014.97

164. Adoamnei E, Mendiola J, Vela-Soria F, Fernández MF, Olea N, Jørgensen N, et al. Urinary Bisphenol A Concentrations Are Associated With 
Reproductive Parameters in Young Men. Environ Res (2018) 161:122-8. doi: 10.1016/j.envres.2017.11.002

165. Caporossi L, Alteri A, Campo G, Paci E, Tranfo G, Capanna S, et al. Cross Sectional Study on Exposure to BPA and Phthalates and Semen Parameters in Men Attending a Fertility Center. Int J Environ Res Public Health (2020) 17(2):489. doi: 10.3390/ijerph17020489

166. Ji H, Miao M, Liang H, Shi H, Ruan D, Li Y, et al. Exposure of Environmental Bisphenol A in Relation to Routine Sperm Parameters and Sperm Movement Characteristics Among Fertile Men. Sci Rep (2018) 8(1):1-9. doi: 10.1038/ s41598-018-35787-5

167. Kranvogl R, Knez J, Miuc A, Vončina E, Vončina DB, Vlaisavljević V. Simultaneous Determination of Phthalates, Their Metabolites, Alkylphenols and Bisphenol a Using GC-MS in Urine of Men With Fertility Problems. Acta Chim Slov (2014) 61(1):110-20.

168. Meeker JD, Ehrlich S, Toth TL, Wright DL, Calafat AM, Trisini AT, et al. Semen Quality and Sperm DNA Damage in Relation to Urinary Bisphenol A Among Men From an Infertility Clinic. Reprod Toxicol (2010) 30(4):532-9. doi: 10.1016/j.reprotox.2010.07.005

169. Mendiola J, Jørgensen N, Andersson AM, Calafat AM, Ye X, Redmon JB, et al. Are Environmental Levels of Bisphenol A Associated With Reproductive Function in Fertile Men? Environ Health Perspect (2010) 118 (9):1286-91. doi: 10.1289/ehp.1002037

170. Li DK, Zhou Z, Miao M, He Y, Wang J, Ferber J, et al. Urine Bisphenol-A (BPA) Level in Relation to Semen Quality. Fertil Steril (2011) 95(2):625630.e4. doi: 10.1016/j.fertnstert.2010.09.026

171. Knez J, Kranvogl R, Breznik BP, Vončina E, Vlaisavljević V. Are Urinary Bisphenol A Levels in Men Related to Semen Quality and Embryo Development after Medically Assisted Reproduction? Fertil Steril (2014) 101(1):215-21.e5. doi: 10.1016/j.fertnstert.2013.09.030

172. Lassen TH, Frederiksen H, Jensen TK, Petersen JH, Joensen UN, Main KM, et al. Urinary Bisphenol A Levels in Young Men: Association With Reproductive Hormones and Semen Quality. Environ Health Perspect (2014) 122(5):478-84. doi: 10.1289/ehp.1307309

173. Goldstone AE, Chen Z, Perry MJ, Kannan K, Louis GMB. Urinary Bisphenol A and Semen Quality, the LIFE Study. Reprod Toxicol (2015) 51:7-13. doi: 10.1016/j.reprotox.2014.11.003

174. Hu W, Dong T, Wang L, Guan Q, Song L, Chen D, et al. Obesity Aggravates Toxic Effect of BPA on Spermatogenesis. Environ Int (2017) 105:56-65. doi: 10.1016/j.envint.2017.04.014

175. Omran GA, Gaber HD, Mostafa NAM, Abdel-Gaber RM, Salah EA. Potential Hazards of Bisphenol A Exposure to Semen Quality and Sperm DNA Integrity Among Infertile Men. Reprod Toxicol (2018) 81:188-95. doi: 10.1016/j.reprotox.2018.08.010

176. Pollard SH, Cox KJ, Blackburn BE, Wilkins DG, Carrell DT, Stanford JB, et al. Male Exposure to Bisphenol A (BPA) and Semen Quality in the Home Observation of Periconceptional Exposures (HOPE) Cohort. Reprod Toxicol (2019) 90:82-7. doi: 10.1016/j.reprotox.2019.08.014

177. Radwan M, Wielgomas B, Dziewirska E, Radwan P, Kałużny P, Klimowska A, et al. Urinary Bisphenol A Levels and Male Fertility. Am J Mens Health (2018) 12(6):2144-51. doi: 10.1177/1557988318799163

178. Vitku J, Sosvorova L, Chlupacova T, Hampl R, Hill M, Sobotka V, et al. Differences in Bisphenol A and Estrogen Levels in the Plasma and Seminal Plasma of Men With Different Degrees of Infertility. Physiol Res (2015) 64 (Suppl 2):S303-11. doi: 10.33549/physiolres.933090

179. Vitku J, Heracek J, Sosvorova L, Hampl R, Chlupacova T, Hill M, et al. Associations of Bisphenol A and Polychlorinated Biphenyls With Spermatogenesis and Steroidogenesis in Two Biological Fluids From Men Attending an Infertility Clinic. Environ Int (2016) 89-90:166-73. doi: 10.1016/j.envint.2016.01.021

180. Ghayda RA, Williams PL, Chavarro JE, Ford JB, Souter I, Calafat AM, et al. Urinary Bisphenol S Concentrations: Potential Predictors of and Associations With Semen Quality Parameters Among Men Attending a Fertility Center. Environ Int (2019) 131:1-8. doi: 10.1016/j.envint. 2019.105050

181. Adoamnei E, Mendiola J, Moñino-García M, Vela-Soria F, Iribarne-Durán LM, Fernández MF, et al. Urinary Concentrations of Parabens and Reproductive Parameters in Young Men. Sci Total Environ (2018) 621:201-9. doi: 10.1016/j.scitotenv.2017.11.256
182. Meeker JD, Yang T, Ye X, Calafat AM, Hauser R. Urinary Concentrations of Parabens and Serum Hormone Levels, Semen Quality Parameters, and Sperm DNA Damage. Environ Health Perspect (2011) 119(2):252-7. doi: $10.1289 /$ ehp. 1002238

183. Smarr MM, Honda M, Kannan K, Chen Z, Kim S, Louis GMB. Male Urinary Biomarkers of Antimicrobial Exposure and Bi-Directional Associations With Semen Quality Parameters. Reprod Toxicol (2018) 77:103-8. doi: 10.1016/ j.reprotox.2018.02.008

184. Albert O, Huang JY, Aleksa K, Hales BF, Goodyer CG, Robaire B, et al. Exposure to Polybrominated Diphenyl Ethers and Phthalates in Healthy Men Living in the Greater Montreal Area: A Study of Hormonal Balance and Semen Quality. Environ Int (2018) 116(January):165-75. doi: 10.1016/ j.envint.2018.04.012

185. Axelsson J, Rylander L, Rignell-Hydbom A, Jönsson BAG, Lindh CH, Giwercman A. Phthalate Exposure and Reproductive Parameters in Young Men From the General Swedish Population. Environ Int (2015) 85:54-60. doi: 10.1016/j.envint.2015.07.005

186. Chang WH, Wu MH, Pan HA, Guo PL, Lee CC. Semen Quality and InsulinLike Factor 3: Associations With Urinary and Seminal Levels of Phthalate Metabolites in Adult Males. Chemosphere (2017) 173:594-602. doi: 10.1016/ j.chemosphere.2017.01.056

187. Chen Q, Yang H, Zhou N, Sun L, Bao H, Tan L, et al. Phthalate Exposure, Even Below US EPA Reference Doses, was Associated With Semen Quality and Reproductive Hormones: Prospective MARHCS Study in General Population. Environ Int (2017) 104:58-68. doi: 10.1016/j.envint.2017.04.005

188. Joensen UN, Frederiksen H, Jensen MB, Lauritsen MP, Olesen IA, Lassen TH, et al. Phthalate Excretion Pattern and Testicular Function: A Study of 881 Healthy Danish Men. Environ Health Perspect (2012) 120(10):1397-403. doi: 10.1289/ehp.1205113

189. Jurewicz J, Radwan M, Sobala W, Ligocka D, Radwan P, Bochenek M, et al. Human Urinary Phthalate Metabolites Level and Main Semen Parameters, Sperm Chromatin Structure, Sperm Aneuploidy and Reproductive Hormones. Reprod Toxicol (2013) 42:232-41. doi: 10.1016/j.reprotox.2013.10.001

190. Han X, Cui Z, Zhou N, Ma M, Li L, Li Y, et al. Urinary Phthalate Metabolites and Male Reproductive Function Parameters in Chongqing General Population, China. Int J Hyg Environ Health (2014) 217(2-3):271-8. doi: 10.1016/j.ijheh.2013.06.006

191. Pant N, Shukla M, Kumar Patel D, Shukla Y, Mathur N, Kumar Gupta Y, et al. Correlation of Phthalate Exposures With Semen Quality. Toxicol Appl Pharmacol (2008) 231(1):112-6. doi: 10.1016/j.taap.2008.04.001

192. Pant N, Pant AB, Shukla M, Mathur N, Gupta YK, Saxena DK. Environmental and Experimental Exposure of Phthalate Esters: The Toxicological Consequence on Human Sperm. Hum Exp Toxicol (2011) 30(6):507-14. doi: 10.1177/0960327110374205

193. Pant N, Kumar G, Upadhyay AD, Patel DK, Gupta YK, Chaturvedi PK. Reproductive Toxicity of Lead, Cadmium, and Phthalate Exposure in Men. Environ Sci Pollut Res (2014) 21(18):11066-74. doi: 10.1007/s11356-0142986-5

194. Liu L, Bao H, Liu F, Zhang J, Shen H. Phthalates Exposure of Chinese Reproductive Age Couples and Its Effect on Male Semen Quality, a Primary Study. Environ Int (2012) 42(1):78-83. doi: 10.1016/ j.envint.2011.04.005

195. Pan Y, Jing J, Dong F, Yao Q, Zhang W, Zhang H, et al. Association Between Phthalate Metabolites and Biomarkers of Reproductive Function in 1066 Chinese Men of Reproductive Age. J Hazard Mater (2015) 300:729-36. doi: 10.1016/j.jhazmat.2015.08.011

196. Smarr MM, Kannan K, Sun L, Honda M, Wang W, Karthikraj R, et al. Preconception Seminal Plasma Concentrations of Endocrine Disrupting Chemicals in Relation to Semen Quality Parameters Among Male Partners Planning for Pregnancy. Environ Res (2018) 167:78-86. doi: 10.1016/ j.envres.2018.07.004

197. Thurston SW, Mendiola J, Bellamy AR, Levine H, Wang C, Sparks A, et al. Phthalate Exposure and Semen Quality in Fertile US Men. Andrology (2016) 4(4):632-8. doi: 10.1111/andr.12124

198. Wang YX, Zeng Q, Sun Y, Yang P, Wang P, Li J, et al. Semen Phthalate Metabolites, Semen Quality Parameters and Serum Reproductive Hormones: A Cross-Sectional Study in China. Environ Pollut (2016) 211:173-82. doi: 10.1016/j.envpol.2015.12.052 
199. Specht IO, Toft G, Hougaard KS, Lindh CH, Lenters V, Jönsson BAG, et al. Associations Between Serum Phthalates and Biomarkers of Reproductive Function in 589 Adult Men. Environ Int (2014) 66:146-56. doi: 10.1016/ j.envint.2014.02.002

200. Miranda-Contreras L, Gómez-Pérez R, Rojas G, Cruz I, Berrueta L, Salmen S, et al. Occupational Exposure to Organophosphate and Carbamate Pesticides Affects Sperm Chromatin Integrity and Reproductive Hormone Levels Among Venezuelan Farm Workers. J Occup Health (2013) 55(3):195-203. doi: 10.1539/joh.12-0144-FS

201. Melgarejo M, Mendiola J, Koch HM, Moñino-García M, Noguera-Velasco JA, Torres-Cantero AM. Associations Between Urinary Organophosphate Pesticide Metabolite Levels and Reproductive Parameters in Men From an Infertility Clinic. Environ Res (2015) 137:292-8. doi: 10.1016/j.envres.2015.01.004

202. Perry MJ, Venners SA, Chen X, Liu X, Tang G, Xing H, et al. Organophosphorous Pesticide Exposures and Sperm Quality. Reprod Toxicol (2011) 31(1):75-9. doi: 10.1016/j.reprotox.2010.08.006

203. Meeker JD, Barr DB, Hauser R. Human Semen Quality and Sperm DNA Damage in Relation to Urinary Metabolites of Pyrethroid Insecticides. Hum Reprod (2008) 23(8):1932-40. doi: 10.1093/humrep/den242

204. Ji G, Xia Y, Gu A, Shi X, Long Y, Song L, et al. Effects of Non-Occupational Environmental Exposure to Pyrethroids on Semen Quality and Sperm DNA Integrity in Chinese Men. Reprod Toxicol (2011) 31(2):171-6. doi: 10.1016/ j.reprotox.2010.10.005

205. Imai K, Yoshinaga J, Yoshikane M, Shiraishi H, Mieno MN, Yoshiike M, et al. Pyrethroid Insecticide Exposure and Semen Quality of Young Japanese Men. Reprod Toxicol (2014) 43:38-44. doi: 10.1016/j.reprotox.2013.10.010

206. Radwan M, Jurewicz J, Wielgomas B, Sobala W, Piskunowicz M, Radwan P, et al. Semen Quality and the Level of Reproductive Hormones After Environmental Exposure to Pyrethroids. J Occup Environ Med (2014) 56 (11):1113-9. doi: 10.1097/JOM.0000000000000297

207. Xia Y, Han Y, Wu B, Wang S, Gu A, Lu N, et al. The Relation Between Urinary Metabolite of Pyrethroid Insecticides and Semen Quality in Humans. Fertil Steril (2008) 89(6):1743-50. doi: 10.1016/j.fertnstert.2007.05.049

208. Abdelouahab N, AinMelk Y, Takser L. Polybrominated Diphenyl Ethers and Sperm Quality. Reprod Toxicol (2011) 31(4):546-50. doi: 10.1016/ j.reprotox.2011.02.005

209. Abou Ghayda R, Sergeyev O, Burns IS, Williams PL, Lee MM, Korrick SA, et al. Peripubertal Serum Concentrations of Organochlorine Pesticides and Semen Parameters in Russian Young Men. Environ Int (2020) 144:1-7. doi: 10.1016/j.envint.2020.106085

210. Aneck-Hahn NH, Schulenburg GW, Bornman MS, Farias P, De Jager C. Impaired Semen Quality Associated With Environmental DDT Exposure in Young Men Living in a Malaria Area in the Province, South Africa. J Androl (2007) 28(3):423-34. doi: 10.2164/jandrol.106.001701

211. Ayotte P, Giroux S, Dewailly E, Hernández Avila M, Farias P, Danis R, et al. DDT Spraying for Malaria Control and Reproductive Function in Mexican Men. Epidemiology (2001) 12:366-7. doi: 10.1097/00001648-20010500000022

212. De Jager C, Farias P, Barraza-Villarreal A, Avila MH, Ayotte P, Dewailly E, et al. Reduced Seminal Parameters Associated With Environmental DDT Exposure and $\mathrm{P}, \mathrm{P}^{\prime}-\mathrm{DDE}$ Concentrations in Men in Chiapas, Mexico: A Cross-Sectional Study. J Androl (2006) 27(1):16-27. doi: 10.2164/ jandrol.05121

213. Hauser R, Chen Z, Pothier L, Ryan L, Altshul L. The Relationship Between Human Semen Parameters and Environmental Exposure to Polychlorinated Biphenyls and P,P'-DDE. Environ Health Perspect (2003) 111(12):1505-11. doi: 10.1289/ehp.6175

214. Mumford SL, Kim S, Chen Z, Gore-Langton RE, Boyd Barr D, Buck Louis GM. Persistent Organic Pollutants and Semen Quality: The LIFE Study. Chemosphere (2015) 135:427-35. doi: 10.1016/j.chemosphere.2014.11.015

215. Pant N, Shukla M, Upadhyay AD, Chaturvedi PK, Saxena DK, Gupta YK. Association Between Environmental Exposure to P, P'-DDE and Lindane and Semen Quality. Environ Sci Pollut Res (2014) 21(18):11009-16. doi: 10.1007/s11356-014-2965-x

216. Specht IO, Bonde JPE, Toft G, Giwercman A, Spanò M, Bizzaro D, et al. Environmental Hexachlorobenzene Exposure and Human Male Reproductive Function. Reprod Toxicol (2015) 58:8-14. doi: 10.1016/ j.reprotox.2015.07.074
217. Louis GM, Chen Z, Schisterman EF, Kim S, Sweeney AM, Sundaram R, et al. Perfluorochemicals and Human Semen Quality: The LIFE Study. Environ Health Perspect (2015) 123(1):57-63. doi: 10.1289/ehp.1307621

218. Joensen UN, Bossi R, Leffers H, Jensen AA, Skakkebæk NE, Jørgensen N. Do Perfluoroalkyl Compounds Impair Human Semen Quality? Environ Health Perspect (2009) 117(6):923-7. doi: 10.1289/ehp.0800517

219. Lewis RC, Johns LE, Meeker JD. Serum Biomarkers of Exposure to Perfluoroalkyl Substances in Relation to Serum Testosterone and Measures of Thyroid Function Among Adults and Adolescents From NHANES 20112012. Int J Environ Res Public Health (2015) 12(6):6098-114. doi: 10.3390/ ijerph120606098

220. Petersen MS, Halling J, Jørgensen N, Nielsen F, Grandjean P, Jensen TK, et al. Reproductive Function in a Population of Young Faroese Men With Elevated Exposure to Polychlorinated Biphenyls (PCBs) and Perfluorinated Alkylate Substances (PFAS). Int J Environ Res Public Health (2018) 15(9):114. doi: 10.3390/ijerph15091880

221. Joensen UN, Veyrand B, Antignac JP, Blomberg Jensen M, Petersen JH, Marchand P, et al. PFOS (Perfluorooctanesulfonate) in Serum is Negatively Associated With Testosterone Levels, But Not With Semen Quality, in Healthy Men. Hum Reprod (2013) 28(3):599-608. doi: 10.1093/humrep/des425

222. Raymer JH, Michael LC, Studabaker WB, Olsen GW, Sloan CS, Wilcosky T, et al. Concentrations of Perfluorooctane Sulfonate (PFOS) and Perfluorooctanoate (PFOA) and Their Associations With Human Semen Quality Measurements. Reprod Toxicol (2012) 33(4):419-27. doi: 10.1016/ j.reprotox.2011.05.024

223. Toft G, Jönsson BAG, Lindh CH, Giwercman A, Spano M, Heederik D, et al. Exposure to Perfluorinated Compounds and Human Semen Quality in Arctic and European Populations. Hum Reprod (2012) 27(8):2532-40. doi: 10.1093/humrep/des185

224. Dallinga JW, Moonen EJC, Dumoulin JCM, Evers JLH, Geraedts JPM, Kleinjans JCS. Decreased Human Semen Quality and Organochlorine Compounds in Blood. Hum Reprod (2002) 17(8):1973-9. doi: 10.1093/ humrep/17.8.1973

225. Mínguez-Alarcón L, Sergeyev O, Burns JS, Williams PL, Lee MM, Korrick SA, et al. A Longitudinal Study of Peripubertal Serum Organochlorine Concentrations and Semen Parameters in Young Men: The Russian Children's Study. Environ Health Perspect (2017) 125(3):460-6. doi: 10.1289/EHP25

226. Paul R, Moltó J, Ortuño N, Romero A, Bezos C, Aizpurua J, et al. Relationship Between Serum Dioxin-Like Polychlorinated Biphenyls and Post-Testicular Maturation in Human Sperm. Reprod Toxicol (2017) 73:31221. doi: 10.1016/j.reprotox.2017.07.004

227. Petersen MS, Halling J, Weihe P, Jensen TK, Grandjean P, Nielsen F, et al. Spermatogenic Capacity in Fertile Men With Elevated Exposure to Polychlorinated Biphenyls. Environ Res (2015) 138:345-51. doi: 10.1016/ j.envres.2015.02.030

228. Richthoff J, Rylander L, Jönsson BAG, Åkesson H, Hagmar L, Nilsson-Ehle P, et al. Serum Levels of $2,2^{\prime}, 4,4^{\prime}, 5,5^{\prime}$-Hexaclorobiphenyl (CB-153) in Relation to Markers of Reproductive Function in Young Males From the General Swedish Population. Environ Health Perspect (2003) 111(4):409-13. doi: 10.1289/ehp.5767

229. Rignell-Hydbom A, Rylander L, Giwercman A, Jönsson BAG, Nilsson-Ehle P, Hagmar L. Exposure to CB-153 and P,P'-DDE and Male Reproductive Function. Hum Reprod (2004) 19(9):2066-75. doi: 10.1093/humrep/deh362

230. Rignell-Hydbom A, Rylander L, Giwercman A, Jönsson BAG, Lindh C, Eleuteri $\mathrm{P}$, et al. Exposure to $\mathrm{PCBs}$ and $\mathrm{P}, \mathrm{P}^{\prime}-\mathrm{DDE}$ and Human Sperm Chromatin Integrity. Environ Health Perspect (2005) 113(2):175-9. doi: 10.1289/ehp.7252

231. Rozati R, Reddy PP, Reddanna P, Mujtaba R. Role of Environmental Estrogens in the Deterioration of Male Factor Fertility. Fertil Steril (2002) 78(6):1187-94. doi: 10.1016/S0015-0282(02)04389-3

232. Spanò M, Toft G, Hagmar L, Eleuteri $\mathrm{P}$, Rescia M, Rignell-Hydbom A, et al. Exposure to $\mathrm{PCB}$ and $\mathrm{P}, \mathrm{P}^{\prime}-\mathrm{DDE}$ in European and Inuit Populations: Impact on Human Sperm Chromatin Integrity. Hum Reprod (2005) 20(12):3488-99. doi: 10.1093/humrep/dei297

233. Toft G, Rignell-Hydbom A, Tyrkiel E, Shvets M, Giwercman A, Lindh CH, et al. Semen Quality and Exposure to Persistent Organochlorine Pollutants. Epidemiology (2006) 17(4):450-8. doi: 10.1097/01.ede.0000221769.41028.d2 
234. Yu Yj, Lin Bg, Liang W, Li Lz, Hong Y, Chen Xc, et al. Associations Between PBDEs Exposure From House Dust and Human Semen Quality at an EWaste Areas in South China-A Pilot Study. Chemosphere (2018) 198:266-73. doi: 10.1016/j.chemosphere.2018.01.150

235. Akutsu K, Takatori S, Nozawa S, Yoshiike M, Nakazawa H, Hayakawa K, et al. Polybrominated Diphenyl Ethers in Human Serum and Sperm Quality. Bull Environ Contam Toxicol (2008) 80(4):345-50. doi: 10.1007/s00128-0089370-4

236. Toft G, Lenters V, Vermeulen R, Heederik D, Thomsen C, Becher G, et al. Exposure to Polybrominated Diphenyl Ethers and Male Reproductive Function in Greenland, Poland and Ukraine. Reprod Toxicol (2014) 43:17. doi: 10.1016/j.reprotox.2013.10.002

237. Pant N, Pant AB, Chaturvedi PK, Shukla M, Mathur N, Gupta YK, et al. Semen Quality of Environmentally Exposed Human Population: The Toxicological Consequence. Environ Sci Pollut Res (2013) 20(11):8274-81. doi: 10.1007/s11356-013-1813-8

238. Lin Bg, Chen Cr, Chen Xc, Qiao J, Yan Qx, Yang P, et al. Effects of Organochlorine Exposure on Male Reproductive Disorders in an Electronic Waste Area of South China. Environ Int (2021) 147:106318. doi: 10.1016/j.envint.2020.106318

239. Wilson BW, Arrieta DE, Henderson JD. Monitoring Cholinesterases to Detect Pesticide Exposure. Chem Biol Interact (2005) 157-8:253-6. doi: 10.1016/j.cbi.2005.10.043

240. Sudakin DL, Stone DL. Dialkyl Phosphates as Biomarkers of Organophosphates: The Current Divide Between Epidemiology and Clinical Toxicology. Clin Toxicol (2011) 49(9):771-81. doi: 10.3109/ 15563650.2011.624101

241. Ghafouri-Khosrowshahi A, Ranjbar A, Mousavi L, Nili-Ahmadabadi H, Ghaffari F, Zeinvand-Lorestani H, et al. Chronic Exposure to Organophosphate Pesticides as an Important Challenge in Promoting Reproductive Health: A Comparative Study. J Educ Health Promot (2019) 8(1):1-6. doi: 10.4103/jehp.jehp_148_19

242. Hauser R, Williams P, Altshul L, Calafat AM. Evidence of Interaction Between Polychlorinated Biphenyls and Phthalates in Relation to Human Sperm Motility. Environ Health Perspect (2005) 113(4):425-30. doi: 10.1289/ ehp.7305

243. Hsu PC, Li MC, Lee YC, Kuo PL, Guo YL. Polychlorinated Biphenyls and Dibenzofurans Increased Abnormal Sperm Morphology Without Alterations in Aneuploidy: The Yucheng Study. Chemosphere (2016) 165 (1):294-7. doi: 10.1016/j.chemosphere.2016.09.035

244. Galloway T, Cipelli R, Guralnik J, Ferrucci L, Bandinelli S, Corsi AM, et al. Daily Bisphenol a Excretion and Associations With Sex Hormone Concentrations: Results From the InCHIANTI Adult Population Study. Environ Health Perspect (2010) 118(11):1603-8. doi: 10.1289/ehp.1002367

245. Hanaoka T, Kawamura N, Hara K, Tsugane S. Urinary Bisphenol A and Plasma Hormone Concentrations in Male Workers Exposed to Bisphenol A Diglycidyl Ether and Mixed Organic Solvents. Occup Environ Med (2002) 59 (9):625-8. doi: 10.1136/oem.59.9.625

246. Scinicariello F, Buser MC. Serum Testosterone Concentrations and Urinary Bisphenol a, Benzophenone-3, Triclosan, and Paraben Levels in Male and Female Children and Adolescents: NHANES 2011-2012. Environ Health Perspect (2016) 124(12):1898-904. doi: 10.1289/EHP150

247. Li M, Wang T, Xu Y, Zhang J, Xu B, Xu M, et al. Association of Bisphenol a Exposure With Circulating Sex Hormone Concentrations in Men and Postmenopausal Women. BioMed Environ Sci (2014) 27:633-6. doi: 10.3967/bes2014.096

248. Liang H, Xu W, Chen J, Shi H, Zhu J, Liu X, et al. The Association Between Exposure to Environmental Bisphenol A and Gonadotropic Hormone Levels Among Men. PloS One (2017) 12(1):1-12. doi: 10.1371/journal.pone.0169217

249. Liu X, Miao M, Zhou Z, Gao E, Chen J, Wang J, et al. Exposure to BisphenolA and Reproductive Hormones Among Male Adults. Environ Toxicol Pharmacol (2015) 39(2):934-41. doi: 10.1016/j.etap.2015.03.007

250. Manfo FPT, Harthé C, Nantia EA, Dechaud H, Tchana AN, Zabot MT, et al. Bisphenol A Differentially Affects Male Reproductive Function Biomarkers in a Reference Population and Agro Pesticides Users From Djutitsa, Cameroon. Toxicol Ind Health (2019) 35(4):324-35. doi: 10.1177/ 0748233719838437

251. Meeker JD, Calafat AM, Hauser R. Urinary Bisphenol A Concentrations in Relation to Serum Thyroid and Reproductive Hormone Levels in Men From an Infertility Clinic. Environ Sci Technol (2010) 44(4):1458-63. doi: 10.1021/ es 9028292

252. Zhou Q, Miao M, Ran M, Ding L, Bai L, Wu T, et al. Serum Bisphenol-A Concentration and Sex Hormone Levels in Men. Fertil Steril (2013) 100 (2):478-82. doi: 10.1016/j.fertnstert.2013.04.017

253. Zhuang W, Wu K, Wang Y, Zhu H, Deng Z, Peng L, et al. Association of Serum Bisphenol-A Concentration and Male Reproductive Function Among Exposed Workers. Arch Environ Contam Toxicol (2015) 68(1):38-45. doi: 10.1007/s00244-014-0078-7

254. Guo LC, Pan S, Yu S, Liu T, Xiao J, Zhu B, et al. Human Sex Hormone Disrupting Effects of New Flame Retardants and Their Interactions With Polychlorinated Biphenyls, Polybrominated Diphenyl Ethers, a Case Study in South China. Environ Sci Technol (2018) 52(23):13935-41. doi: 10.1021/ acs.est.8b01540

255. Makey CM, McClean MD, Braverman LE, Pearce EN, Sjödin A, Weinberg J, et al. Polybrominated Diphenyl Ether Exposure and Reproductive Hormones in North American Men. Reprod Toxicol (2016) 62:46-52. doi: 10.1016/ j.reprotox.2016.04.009

256. Turyk ME, Persky VW, Imm P, Knobeloch L, Chatterton R, Anderson HA. Hormone Disruption by PBDEs in Adult Male Sport Fish Consumers. Environ Health Perspect (2008) 116(12):1635-41. doi: 10.1289/ehp.11707

257. Giwercman A, Rignell-Hydbom A, Toft G, Rylander L, Hagmar L, Lindh C, et al. Reproductive Hormone Levels in Men Exposed to Persistent Organohalogen Pollutants: A Study of Inuit and Three European Cohorts. Environ Health Perspect (2006) 114(9):1348-53. doi: 10.1289/ehp.8935

258. Al-Saleh I, Coskun S, Al-Doush I, Al-Rajudi T, Abduljabbar M, Al-Rouqi R, et al. The Relationships Between Urinary Phthalate Metabolites, Reproductive Hormones and Semen Parameters in Men Attending In Vitro Fertilization Clinic. Sci Total Environ (2019) 658:982-95. doi: 10.1016/j.scitotenv.2018.12.261

259. Chang WH, Li SS, Wu MH, Pan HA, Lee CC. Phthalates Might Interfere With Testicular Function by Reducing Testosterone and Insulin-Like Factor 3 Levels. Hum Reprod (2015) 30(11):2658-70. doi: 10.1093/ humrep/dev225

260. Henrotin JB, Feigerlova E, Robert A, Dziurla M, Burgart M, Lambert-Xolin AM, et al. Decrease in Serum Testosterone Levels After Short-Term Occupational Exposure to Diisononyl Phthalate in Male Workers. Occup Environ Med (2020) 77(4):214-22. doi: 10.1136/oemed-2019-106261

261. Chen SY, Hwang JS, Sung FC, Lin CY, Hsieh CJ, Chen PC, et al. Mono-2Ethylhexyl Phthalate Associated With Insulin Resistance and Lower Testosterone Levels in a Young Population. Environ Pollut (2017) 225:112-7. doi: 10.1016/j.envpol.2017.03.037

262. Duty SM, Calafat AM, Silva MJ, Ryan L, Hauser R. Phthalate Exposure and Reproductive Hormones in Adult Men. Hum Reprod (2005) 20(3):604-10. doi: 10.1093/humrep/deh656

263. Lenters V, Portengen L, Smit LAM, Jönsson BAG, Giwercman A, Rylander L, et al. Phthalates, Perfluoroalkyl Acids, Metals and Organochlorines and Reproductive Function: A Multipollutant Assessment in Greenlandic, Polish and Ukrainian Men. Occup Environ Med (2015) 72(6):385-93. doi: 10.1136/ oemed-2014-102264

264. Meeker JD, Calafat AM, Hauser R. Urinary Metabolites of Di(2-Ethylhexyl) Phthalate Are Associated With Decreased Steroid Hormone Leveis in Adult Men. J Androl (2009) 30(3):287-97. doi: 10.2164/jandrol.108.006403

265. Meeker JD, Ferguson KK. Urinary Phthalate Metabolites Are Associated With Decreased Serum Testosterone in Men, Women, and Children From NHANES 2011-2012. J Clin Endocrinol Metab (2014) 99(11):4346. doi: $10.1210 /$ jc. $2014-2555$

266. Mendiola J, Jørgensen N, Andersson AM, Calafat AM, Silva MJ, Redmon JB, et al. Associations Between Urinary Metabolites of Di(2-Ethylhexyl) Phthalate and Reproductive Hormones in Fertile Men. Int J Androl (2011) 34(4 PART 1):369-78. doi: 10.1111/j.1365-2605.2010.01095.x

267. Wang YX, Zeng Q, Sun Y, You L, Wang P, Li M, et al. Phthalate Exposure in Association With Serum Hormone Levels, Sperm DNA Damage and Spermatozoa Apoptosis: A Cross-Sectional Study in China. Environ Res (2016) 150:557-65. doi: 10.1016/j.envres.2015.11.023

268. Woodward MJ, Obsekov V, Jacobson MH, Kahn LG, Trasande L. Phthalates and Sex Steroid Hormones Among Men From NHANES, 2013-2016. J Clin Endocrinol Metab (2020) 105(4):e1225-34. doi: 10.1210/clinem/dgaa039 
269. Den Hond E, Tournaye H, De Sutter P, Ombelet W, Baeyens W, Covaci A, et al. Human Exposure to Endocrine Disrupting Chemicals and Fertility: A Case-Control Study in Male Subfertility Patients. Environ Int (2015) 84:15460. doi: 10.1016/j.envint.2015.07.017

270. Specht IO, Hougaard KS, Spanò M, Bizzaro D, Manicardi GC, Lindh CH, et al. Sperm DNA Integrity in Relation to Exposure to Environmental Perfluoroalkyl Substances - A Study of Spouses of Pregnant Women in Three Geographical Regions. Reprod Toxicol (2012) 33(4):577-83. doi: 10.1016/j.reprotox.2012.02.008

271. Aguilar-Garduño C, Lacasaña M, Blanco-Muñoz J, Rodríguez-Barranco M, Hernández AF, Bassol S, et al. Changes in Male Hormone Profile After Occupational Organophosphate Exposure. A Longitudinal Study. Toxicology (2013) 307:55-65. doi: 10.1016/j.tox.2012.11.001

272. Bornman M, Delport R, Farías P, Aneck-Hahn N, Patrick S, Millar RP, et al. Alterations in Male Reproductive Hormones in Relation to Environmental DDT Exposure. Environ Int (2018) 113:281-9. doi: 10.1016/j.envint.2017.12.039

273. Han Y, Xia Y, Han J, Zhou J, Wang S, Zhu P, et al. The Relationship of 3-PBA Pyrethroids Metabolite and Male Reproductive Hormones Among NonOccupational Exposure Males. Chemosphere (2008) 72(5):785-90. doi: 10.1016/j.chemosphere.2008.03.058

274. Martin SA, Harlow SD, Sowers MF, Longnecker MP, Garabrant D, Shore DL, et al. DDT Metabolite and Androgens in African-American Farmers. Epidemiology (2002) 13(4):454-8. doi: 10.1097/00001648-200207000-00014

275. Panuwet P, Ladva C, Barr DB, Prapamontol T, Meeker JD, D'Souza PE, et al. Investigation of Associations Between Exposures to Pesticides and Testosterone Levels in Thai Farmers. Arch Environ Occup Heal (2018) 73 (4):205-18. doi: 10.1080/19338244.2017.1378606

276. Meeker JD, Ryan L, Barr DB, Hauser R. Exposure to Nonpersistent Insecticides and Male Reproductive Hormones. Epidemiology (2006) 17 (1):61-8. doi: 10.1097/01.ede.0000190602.14691.70

277. Meeker JD, Ravi SR, Barr DB, Hauser R. Circulating Estradiol in Men Is Inversely Related to Urinary Metabolites of Nonpersistent Insecticides. Reprod Toxicol (2008) 25(2):184-91. doi: 10.1016/j.reprotox.2007.12.005

278. Meeker JD, Barr DB, Hauser R. Pyrethroid Insecticide Metabolites Are Associated With Serum Hormone Levels in Adult Men. Reprod Toxicol (2009) 27(2):155-60. doi: 10.1016/j.reprotox.2008.12.012

279. Omoike OE, Lewis RC, Meeker JD. Association Between Urinary Biomarkers of Exposure to Organophosphate Insecticides and Serum Reproductive Hormones in Men From NHANES 1999-2002. Reprod Toxicol (2015) 53:99-104. doi: 10.1016/j.reprotox.2015.04.005

280. Yoshinaga J, Imai K, Shiraishi H, Nozawa S, Yoshiike M, Mieno MN, et al. Pyrethroid Insecticide Exposure and Reproductive Hormone Levels in Healthy Japanese Male Subjects. Andrology (2014) 2(3):416-20. doi: 10.1111/j.2047-2927.2014.00202.x

281. Hlisníková H, Petrovičová I, Kolena B, Šidlovská M, Sirotkin A. Effects and Mechanisms of Phthalates' Action on Reproductive Processes and Reproductive Health: A Literature Review. Int J Environ Res Public Health (2020) 17:1-37. doi: 10.3390/ijerph17186811

282. Mendiola J, Jørgensen N, Andersson A-M, Calafat AM, Silva MJ, Redmon JB, et al. Associations Between Urinary Metabolites of Di(2-Ethylhexyl) Phthalate and Reproductive Hormones in Fertile Men. Int J Androl (2011) 34(4pt1):369-78. doi: 10.1111/j.1365-2605.2010.01095.x

283. Mendiola J, Meeker JD, Jørgensen N, Andersson AM, Liu F, Calafat AM, et al. Urinary Concentrations of Di(2-Ethylhexyl) Phthalate Metabolites and Serum Reproductive Hormones: Pooled Analysis of Fertile and Infertile Men. J Androl (2012) 33(3):488-98. doi: 10.2164/jandrol.111.013557

284. Duty SM, Calafat AM, Silva MJ, Ryan L, Hauser R. Phthalate Exposure and Reproductive Hormones in Adult Men. Hum Reprod(2005) 20(3):604-10. doi: 10.1093/humrep/deh656

285. Meeker JD, Calafat AM, Hauser R. Urinary Metabolites of Di(2Ethylhexyl) Phthalate Are Associated With Decreased Steroid Hormone Levels in Adult Men. J Androl (2009) 30(3):287-97. doi: 10.2164/ jandrol.108.006403

286. Goncharov A, Rej R, Negoita S, Schymura M, Santiago-Rivera A, Morse G, et al. Lower Serum Testosterone Associated With Elevated Polychlorinated Biphenyl Concentrations in Native American Men. Environ Health Perspect (2009) 117(9):1454-60. doi: 10.1289/ehp.0800134
287. Hagmar L, Björk J, Sjödin A, Bergman Å, Erfurth EM. Plasma Levels of Persistent Organohalogens and Hormone Levels in Adult Male Humans. Arch Environ Health (2001) 56(2):138-43. doi: 10.1080/00039890109604065

288. Lin Bg, Chen Cr, Chen Xc, Qiao J, Yan Qx, Yang P, et al. Effects of Organochlorine Exposure on Male Reproductive Disorders in an Electronic Waste Area of South China. Environ Int (2021) 147:1-8. doi: 10.1016/j.envint.2020.106318

289. Joensen UN, Veyrand B, Antignac JP, Blomberg Jensen M, Petersen JH, Marchand P, et al. PFOS (Perfluorooctanesulfonate) in Serum Is Negatively Associated With Testosterone Levels, But Not With Semen Quality, in Healthy Men. Hum Reprod (2013) 28(3):599-608. doi: 10.1093/humrep/ des 425

290. Parkin DM, Bray F, Ferlay J, Pisani P. Global Cancer Statistics, 2002. CA Cancer J Clin (2005) 55(2):74-108. doi: 10.3322/canjclin.55.2.74

291. Znaor A, Lortet-Tieulent J, Laversanne M, Jemal A, Bray F. International Testicular Cancer Incidence Trends: Generational Transitions in 38 Countries 1900-1990. Cancer Causes Control (2015) 26(1):151-8. doi: 10.1007/s10552-014-0486-z

292. Park JS, Kim J, Elghiaty A, Ham WS. Recent Global Trends in Testicular Cancer Incidence and Mortality. Med (United States) (2018) 97(37):1-7. doi: 10.1097/MD.0000000000012390

293. Rajpert-De Meyts E, McGlynn KA, Okamoto K, Jewett MA, Bokemeyer C. Testicular Germ Cell Tumours. Lancet (London England) (2016) 387 (10029):1762-74. doi: 10.1016/S0140-6736(15)00991-5

294. Hardell L, Van Bavel B, Lindström G, Eriksson M, Carlberg M, Tuomisto J, et al. In Utero Exposure to Persistent Organic Pollutants in Relation to Testicular Cancer Risk. Int J Androl (2006) 29:228-34. doi: 10.1111/j.13652605.2005.00622.x

295. Hardell L, van Bavel B, Lindström G, Calberg M, Dreifaldt AC, Wijkström H, et al. Increased Concentrations of Polychlorinated Biphenyls, Hexachlorobenzene, and Chlordanes in Mothers of Men With Testicular Cancer. Environ Health Perspect (2003) 111(7):930-4. doi: 10.1289/ehp.5816

296. Purdue MP, Engel LS, Langseth H, Needham LL, Andersen A, Barr DB, et al. Prediagnostic Serum Concentrations of Organochlorine Compounds and Risk of Testicular Germ Cell Tumors. Environ Health Perspect (2009) 117 (10):1514-9. doi: 10.1289/ehp.0800359

297. McGlynn KA, Quraishi SM, Graubard BI, Weber JP, Rubertone MV, Erickson RL. Persistent Organochlorine Pesticides and Risk of Testicular Germ Cell Tumors. J Natl Cancer Inst (2008) 100(9):663-71. doi: 10.1093/ jnci/djn101

298. Giannandrea F, Gandini L, Paoli D, Turci R, Figà-Talamanca I. Pesticide Exposure and Serum Organochlorine Residuals Among Testicular Cancer Patients and Healthy Controls. J Environ Sci Health B (2011) 46(8):780-7. doi: 10.1080/03601234.2012.597704

299. Biggs ML, Davis MD, Eaton DL, Weiss NS, Barr DB, Doody DR, et al. Serum Organochlorine Pesticide Residues and Risk of Testicular Germ Cell Carcinoma: A Population-Based Case-Control Study. Cancer Epidemiol Biomarkers Prev (2008) 17(8):2012-8. doi: 10.1158/1055-9965.EPI-08-0032

300. Hardell L, Van Bavel B, Lindström G, Carlberg M, Eriksson M, Dreifaldt AC, et al. Concentrations of Polychlorinated Biphenyls in Blood and the Risk for Testicular Cancer. Int J Androl (2004) 27(5):282-90. doi: 10.1111/j.13652605.2004.00489.x

301. Paoli D, Giannandrea F, Gallo M, Turci R, Cattaruzza MS, Lombardo F, et al. Exposure to Polychlorinated Biphenyls and Hexachlorobenzene, Semen Quality and Testicular Cancer Risk. J Endocrinol Invest (2015) 38(7):74552. doi: 10.1007/s40618-015-0251-5

302. McGlynn KA, Quraishi SM, Graubard BI, Weber JP, Rubertone MV, Erickson RL. Polychlorinated Biphenyls and Risk of Testicular Germ Cell Tumors. Cancer Res (2009) 69(5):1901-9. doi: 10.1158/0008-5472.CAN-083935

303. Yeshurun S, Hannan AJ. Transgenerational Epigenetic Influences of Paternal Environmental Exposures on Brain Function and Predisposition to Psychiatric Disorders. Mol Psychiatry Nat Publ Group (2019) 24:536-48. doi: $10.1038 / \mathrm{s} 41380-018-0039-\mathrm{z}$

304. Grover MM, Jenkins TG. Transgenerational Epigenetics: A Window Into Paternal Health Influences on Offspring. Urol Clinics North America (2020) 47:219-25. doi: 10.1016/j.ucl.2019.12.010 
305. Sharpe RM. Environmental/lifestyle Effects on Spermatogenesis. Philos Trans R Soc B: Biol Sci R Soc (2010) 365:1697-712. doi: 10.1098/ rstb.2009.0206

Conflict of Interest: The authors declare that the research was conducted in the absence of any commercial or financial relationships that could be construed as a potential conflict of interest.

Publisher's Note: All claims expressed in this article are solely those of the authors and do not necessarily represent those of their affiliated organizations, or those of the publisher, the editors and the reviewers. Any product that may be evaluated in this article, or claim that may be made by its manufacturer, is not guaranteed or endorsed by the publisher.

Copyright (c) 2021 Rodprasert, Toppari and Virtanen. This is an open-access article distributed under the terms of the Creative Commons Attribution License (CC BY). The use, distribution or reproduction in other forums is permitted, provided the original author(s) and the copyright owner(s) are credited and that the original publication in this journal is cited, in accordance with accepted academic practice. No use, distribution or reproduction is permitted which does not comply with these terms. 


\section{GLOSSARY}

\begin{tabular}{|c|c|}
\hline AGD & anogenital distance \\
\hline AhR & aryl hydrocarbon receptor \\
\hline$\beta-\mathrm{HCH}$ & beta-hexachlorocyclohexane \\
\hline beta- & beta-hexachlorocyclohexane \\
\hline $\mathrm{HCCH}$ & \\
\hline BBP & butyl benzyl phthalate \\
\hline $\mathrm{BP}$ & butyl paraben \\
\hline BPA & bisphenol A \\
\hline $\mathrm{BzP}$ & benzyl paraben \\
\hline CASA & computer-assisted semen analysis \\
\hline CDCCA & cis-3-(2,2-dichlorovinyl)-2,2-dimethylcyclopropane carboxylic acid \\
\hline 2,4-D & 2,4-dichlorophenoxyacetic acid \\
\hline 2,4-DDD & 2,4-dichlorodiphenyldichloroethane \\
\hline $4,4^{\prime}-\mathrm{DDD}$ & $\begin{array}{l}\text { 1,1-bis(4-chlorophenyl)-2,2-dichloroethane, 4,4'- } \\
\text { dichlorodiphenyldichloroethane }\end{array}$ \\
\hline DAPS & dialkylphosphates \\
\hline DBCA & cis-2,2-dibromovinyl-2,2-dimethylcyclopropane-1-carboxylic acid \\
\hline DBP & dibutylphthalate \\
\hline DBT & dibutyltin \\
\hline DCCA & 3-(2,2-dichlorovinyl)-2,2-dimethylcyclopropane carboxylic acid \\
\hline DDD & 4,4'-dichlorodiphenyldichloroethane \\
\hline DDE & dichlorodiphenyldichloroethylene \\
\hline $4,4^{\prime}-\mathrm{DDE}$ & 2,2-bis(4-chlorophenyl)-1,1-dichloroethene \\
\hline DDT & dichlorodiphenyltrichloroethane \\
\hline $4,4^{\prime}-\mathrm{DDT}$ & 1,1,1-trichloro-2,2-bis(p-chlorophenyl)ethane \\
\hline $\mathrm{p}, \mathrm{p}^{\prime}-\mathrm{DDT}$ & 1,1,1-trichloro-2,2-bis(4-chlorophenyl)ethane \\
\hline DEDTP & diethyldithiophosphate \\
\hline DEHP & di(2-ethylhexyl) phthalate \\
\hline DEP & diethyl phthalate \\
\hline DETP & diethylthiophosphate \\
\hline 3,4 DHB & 3,4-dihydroxy benzoic acid \\
\hline DiNP & diisononyl phthalate \\
\hline DL-PCBs & dioxin-like polychlorinated biphenyls \\
\hline DMDTP & dimethyldithiophosphate \\
\hline DMP & dimethylphosphate \\
\hline DMTP & dimethylthiophosphate \\
\hline E2 & estradiol \\
\hline EP & ethyl paraben \\
\hline ER & estrogen receptor \\
\hline FAl & free androgen index \\
\hline FSH & follicle-stimulating hormone \\
\hline $\mathrm{FT}$ & free testosterone \\
\hline GW & gestational week \\
\hline $4-\mathrm{HB}$ & 4-hydroxy benzoic acid \\
\hline $\mathrm{HCB}$ & hexachlorobenzene \\
\hline HCE & heptachloroepoxide \\
\hline $\mathrm{HCH}$ & hexachlorocyclohexane \\
\hline $\mathrm{HP}$ & heptyl paraben \\
\hline HPG & hypothalamic-pituitary-gonadal \\
\hline hsd3b & 3 beta-hydroxysteroid dehydrogenase \\
\hline hsd17b & 17ß-Hydroxysteroid dehydrogenase \\
\hline iBuP & isobutyl paraben \\
\hline INSL3 & Insulin-like peptide 3 \\
\hline $\mathrm{LH}$ & luteinizing hormone \\
\hline MAA & methoxyacetic acid \\
\hline
\end{tabular}

(Continued)
Continued

mBP $\quad$ MBP, monobutylphthalate

MBT monobutyltin

$\mathrm{MBzP} \quad$ mono-benzyl phthalate

MCiOP mono-carboxy-iso-octyl phthalate

MCPP mono-3-carboxypropyl-phthalate

MECPP mono(2-ethyl-5-carboxypentyl) phthalate

MEHP monoethylhexyl phthalate

MEHHP mono(2-ethyl-5-hydroxyhexyl) phthalate

MEOHP mono(2-ethyl-5-oxohexyl) phthalate

MEP monoethyl phthalate

MBzP monobenzyl phthalate

MHiNP mono-hydroxy-iso-nonyl phthalate

MiBP monoisobutyl phthalate

MiNP monoisononyl phthalate

MnBP mono-n-butyl phthalate

MOiNP mono-(oxo-iso-nonyl) phthalate

MP methyl paraben

MPW male programming window

1N 1-naphthol

$2 \mathrm{~N} \quad$ 2-naphthol

OCDF octachlorodibenzofuran

$\mathrm{OH}$-EtP ethylprotocatechuic acid

$\mathrm{OH}-\mathrm{MeP}$ methyl-protocatechuic acid

OTCs organotin compounds

PA phthalic acid

3-PBA 3-phenoxybenzoic acid

PBBs polybrominated biphenyls

PCBs polychlorinated biphenyls

PBDEs polybrominated diphenyl ethers

PCDD/Fs polychlorinated dibenzo-p-dioxins and dibenzofurans

PFDA perfluorodecanoic acid

PFDoA perfluorododecanoic acid

PFHpA perfluoroheptanoic acid

PFHpS potassium perfluoro-1-heptanesulfonate

PFHxS perfluorohexane sulfonic acid

PFNA perfluorononanoic acid

PFOA Perfluorooctanoic acid

PFOS perfluorooctanesulfonic acid

PFOSA perfluorooctane sulfonamide

PFTrA perfluorotridecanoic acid

PFUnA perfluoroundecanoic acid

PhAA phenoxyacetic acid

POPs persistent organic pollutants

PP propyl paraben

p,p'-DDE p,p'-dichlorodiphenyldichloroethylene

SHBG sex hormone-binding globulin

StAR steroidogenic acute regulatory protein

$\mathrm{T}$ testosterone

TBT tributyltin

TCPY 3,5,6-trichloro-2-pyridinol

TDCCA trans-2,2-(dichlorovinyl)-2,2-dimethylcyclopropane carboxylic acid

TEQ toxic equivalent

TGCTs testicular germ cell tumors

TPhT triphenyltin

TSC total sperm count

Tा total testosterone

UV ultraviolet

Y year 